Portland State University

PDXScholar

\title{
Tracking Fish and Human Response to Abrupt Environmental Change at Tse-whit-zen: A Large Native American Village on the Olympic Peninsula, Washington State
}

Kathryn Anne Mohlenhoff

Portland State University

Follow this and additional works at: https://pdxscholar.library.pdx.edu/open_access_etds

Part of the Ecology and Evolutionary Biology Commons, and the History of Art, Architecture, and Archaeology Commons

Let us know how access to this document benefits you.

\section{Recommended Citation}

Mohlenhoff, Kathryn Anne, "Tracking Fish and Human Response to Abrupt Environmental Change at Tsewhit-zen: A Large Native American Village on the Olympic Peninsula, Washington State" (2013). Dissertations and Theses. Paper 1052.

https://doi.org/10.15760/etd.1052

This Thesis is brought to you for free and open access. It has been accepted for inclusion in Dissertations and Theses by an authorized administrator of PDXScholar. Please contact us if we can make this document more accessible: pdxscholar@pdx.edu. 
Tracking Fish and Human Response to Abrupt Environmental Change at Tse-whit-zen: A Large Native American Village on the Olympic Peninsula, Washington State

by

Kathryn Anne Mohlenhoff

A thesis submitted in partial fulfillment of the

requirements for the degree of

Master of Science

in

Anthropology

Thesis Committee:

Virginia L. Butler, Chair

Kenneth M. Ames

Shelby L. Anderson

Portland State University

2013 


\begin{abstract}
Evidence of large earthquakes occurring along the Pacific Northwest Coast is reflected in coastal stratigraphy from Oregon to British Columbia, where there also exists an extensive archaeological record of Native American occupation. Tse-whitzen, a large Native American village dating between 1824 and 54 cal B.P. located on the Olympic Peninsula of Washington State, was excavated with exceptionally fine stratigraphic control allowing for precise comparison of natural and cultural records. Here I report on the >10,000 fish remains from one 2x2 m excavation block; this assemblage spans one earthquake event, allowing study of changes in relative taxonomic abundance through time that may coincide with earthquakes or other environmental changes. Results indicate use of a wide range of marine fish taxa including various sculpins (Cottidae), flatfish (Pleuronectiformes), herring (Clupea pallasii) and salmon (Oncorhynchus spp.). This illustrates a highly diverse diet throughout occupation, though relative abundances of more offshore taxa decrease through time in favor of some nearshore taxa, possibly indicating the presence of a coseismic event. This thesis serves as part of a pilot study for a collaborative project that is underway. This larger project addresses human response to both gradual and abrupt environmental change through the analysis of all classes of Tse-whit-zen faunal remains, which provide a link to impacts on animal populations and in turn human subsistence.
\end{abstract}




\section{Acknowledgments}

This thesis has been a communal effort to prepare and produce rather than an individual undertaking. To that end, I have many people to thank for their support and guidance. First and foremost, I would like to thank the Lower Elwha Klallam Tribe for their support of this project. Without them, this work would not be possible. I would like to thank Dr. Laura Phillips at the Burke Museum in Seattle helping with logistics throughout the project. I would like to thank Dr. Doug Kennett and Brendan Culleton at UC-Irvine for running the radiocarbon dates for the pilot study, and to Anna Kagley, Anne Shaffer and Si Simonstad for background information on local fishes. Thank you Ross Smith and Bob Kopperl for the use of your comparative fish skeletons. Thank you to the NSF and the PSU Faculty enhancement grant for funding the pilot study, and thank you to the Association for Washington Archaeology's student research grant for helping me purchase software vital to this work.

Thank you to my friends, cohort members and colleagues. The support and willingness to commiserate and discuss the trials of graduate school over a good Portland beer will be cherished. I'd especially like to thank Tony Hofkamp for all of his help and enthusiasm in identifying bones, rescreening, and providing hours of entertaining discussion in that windowless lab.

To Dr. Sarah Sterling, whose intimate knowledge of this site and how to navigate the site report has been extremely valuable; thank you. I'd like to thank Dr. Shelby Anderson, one of my committee members who graciously stepped in at the 
last minute. Your support and insightful comments on work leading up to and including this thesis have been extremely helpful. I'd like to thank Dr. Kenneth Ames, a member of my thesis committee and an important mentor to me throughout my grad school career. He has given me tremendous guidance and helpful, albeit wellpointed, critique on many class papers that have helped develop this thesis. Ken, thank you for reminding me to breathe. I would especially like to thank Dr. Virginia Butler, my amazing advisor. Without her, I would have never been able to accomplish this thesis. Her enthusiasm and love of archaeology, as well as her patience and helpful guidance, have been vital to my success as a graduate student. It has been a pleasure to work so closely with her for the past three years, especially on the Tsewhit-zen project.

I'd like to thank my family. Your steadfast support has been overwhelming through this process. I especially thank you for providing a sounding board for ideas, worries, fears and frustrations. Finally, I'd like to thank my dogs: Brodie and Riley. Without your unconditional love and cuddles at the end of the day, I surely would have lost my mind long ago. 


\section{Table of Contents}

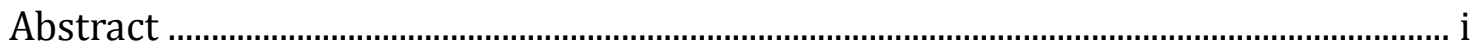

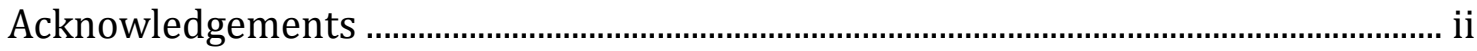

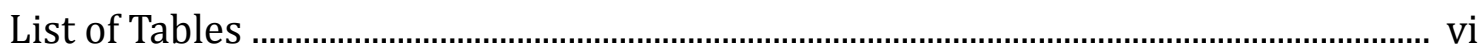

List of Figures .................................................................................................................. vii

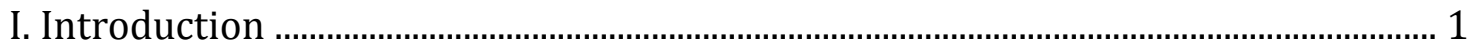

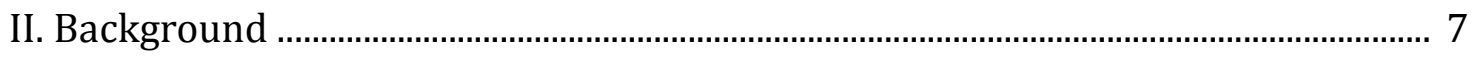

$\begin{array}{ll}\text { CSZ Environmental Overview } & 7\end{array}$

Tse-whit-zen in Cultural Context 9

Abrupt Environmental Change and Marine Resources $\quad 10$

$\begin{array}{ll}\text { Archaeological Evidence } & 15\end{array}$

$\begin{array}{ll}\text { The Value of the Tse-whit-zen Site } & 19\end{array}$

Environmental Setting of Tse-whit-zen $\quad 20$

$\begin{array}{ll}\text { Excavation of Tse-whit-zen } & 22\end{array}$

Taxonomic Identification Issues $\quad 29$

III. Methods and Materials ............................................................................................ 34

Initial Documentation and Processing $\quad 34$

$\begin{array}{ll}\text { Analysis } & 35\end{array}$

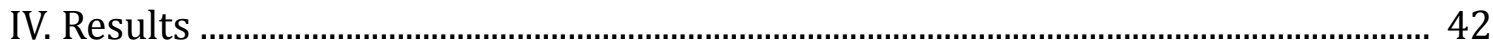

Descriptive Summary of Fish Remains $\quad 43$

Quantification: NISP and MAU 63

$\begin{array}{ll}\text { Sample Size } & 66\end{array}$

Mesh Size $\quad 68$

$\begin{array}{lr}\text { Tse-whit-zen Fish Assemblage } & 69\end{array}$

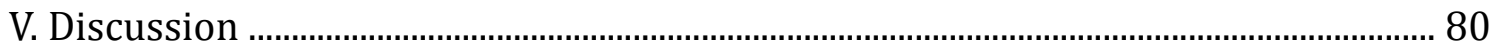

$\begin{array}{lr}\text { Expectations } & 80\end{array}$

Habitat Assignment $\quad 82$

Change over Time in Habitat Use 86

The Impacts of a CSZ Coseismic Event on the Fish and Fisheries of

$\begin{array}{ll}\text { Tse-whit-zen } & 91\end{array}$

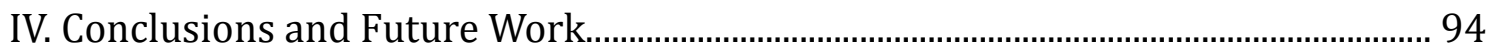


Works Cited .

Appendix A: List of possible taxa for the Strait of Juan de Fuca ................................. 107

Appendix B: Comparative collection specimens for the Tse-whit-zen project ....... 109

Appendix C: Elements used to calculate MAU values for each taxon (vertebra counts from Clothier (1950), Hart (1973), and Butler (1990) ................................................ 111 


\section{List of Tables}

Table 3.1

Table of identifiable elements by taxon 38

Table 4.1

Identified taxa in area A4, Units 17-20 "C" and "CX" bags .

Table 4.2

NISP, MAU and Spearman's ranks for each taxon. Taxa in bold are those with substantial differences in ranks

Table 4.3

Excavated volume and sample size for "C" bags

Table 4.4

Taxonomic representation separated by component: "C" bags. Values in bold are significant at $\mathrm{p}=.05$ 73

Table 4.5

Taxonomic representation: comparison of the interior and exterior AZs of the upper component: “C" bags. Values in bold are significant at $\mathrm{p}=.05 \ldots . . . . . .76$

Table 4.6

Taxonomic representation: comparison of the lower and upper component:

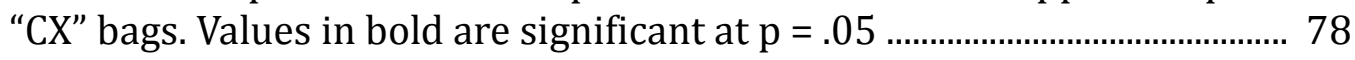

Table 5.1

Assignment of fish taxa to habitat 85

Table 5.2

Distribution of fish in habitat types by AZ. Values in bold are significant at $\mathrm{p}=$ .05 87 


\section{List of Figures}

Figure 1.1

Cascadia Subduction Zone boundary with site locations (modified and used with kind permission from the Oregon Department of Geology and Mineral

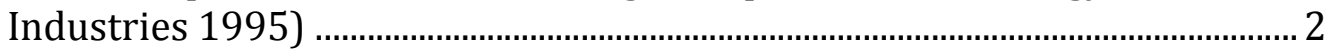

Figure 1.2

Regional map showing the location of Port Angeles on the Olympic Peninsula of Washington State, as well as the location of Tse-whit-zen on the base of Ediz Hook west of Port Angeles, WA (from Sterling et al. 2011) 4

Figure 2.1

Site map of Tse-whit-zen excavation areas (Reetz et al. 2006, 4-3) 24

Figure 2.2

Area A4 of the Tse-whit-zen excavation with thesis (pilot) units highlighted in red (Larson 2006)

Figure 2.3

Assignment of analytic zones for the $2 \times 2$ m pilot unit in Area A4 29

Figure 4.1

Scatter plot showing significant correlation between logNISP and logMAU values 66

Figure 4.2

"C" bags, the relationship between sample size and excavated volume for each analytic zone

68

Figure 4.3

Clustered bar chart comparing taxonomic representation of $>1 / 4$ " mesh recovery with $>1 / 8$ " mesh recovery 69

Figure 4.4

Taxonomic representation for lower and upper component: "C" bags ....... 72

Figure 4.5

Taxonomic representation comparison of upper component interior and exterior assemblages: "C" bags 75

Figure 4.6

Taxonomic representation for lower and upper component: "CX" bags .... 77 
Figure 5.1

Designation of habitat types surrounding Tse-whit-zen ................................ 86

Figure 5.2

Distribution of habitat type by analytic zone before and after the occupation gap: “C” bags ….................................................................................................. 90

Figure 5.3

Comparison of "CX" bags from lower (bottom) to upper (top) component 91 


\section{Introduction}

Project Overview

Along the Northwest Coast of North America, there exists a large record of archaeological village sites, characterized by extensive shell middens and evidence of multiple, large, wooden plank houses. These villages became common in many areas of the coast between 3000-1500 BP, and were inhabited, sometimes for hundreds of years, up until and past Euro-American contact into the $19^{\text {th }}$ century (Ames and Maschner 1999). In the coastline stratigraphy of this same region, researchers have constructed a lengthy record of abrupt environmental events, specifically a record of earthquakes and tsunamis originating at the Cascadia Subduction Zone (CSZ) (Fig 1.1). Evidence of these events can often be detected in the stratigraphy of archaeological sites as sterile sand sheets or abruptly subducted culturally modified material (e.g. Minor and Grant 1996, Hutchinson and McMillan 1997, Losey 2002). 


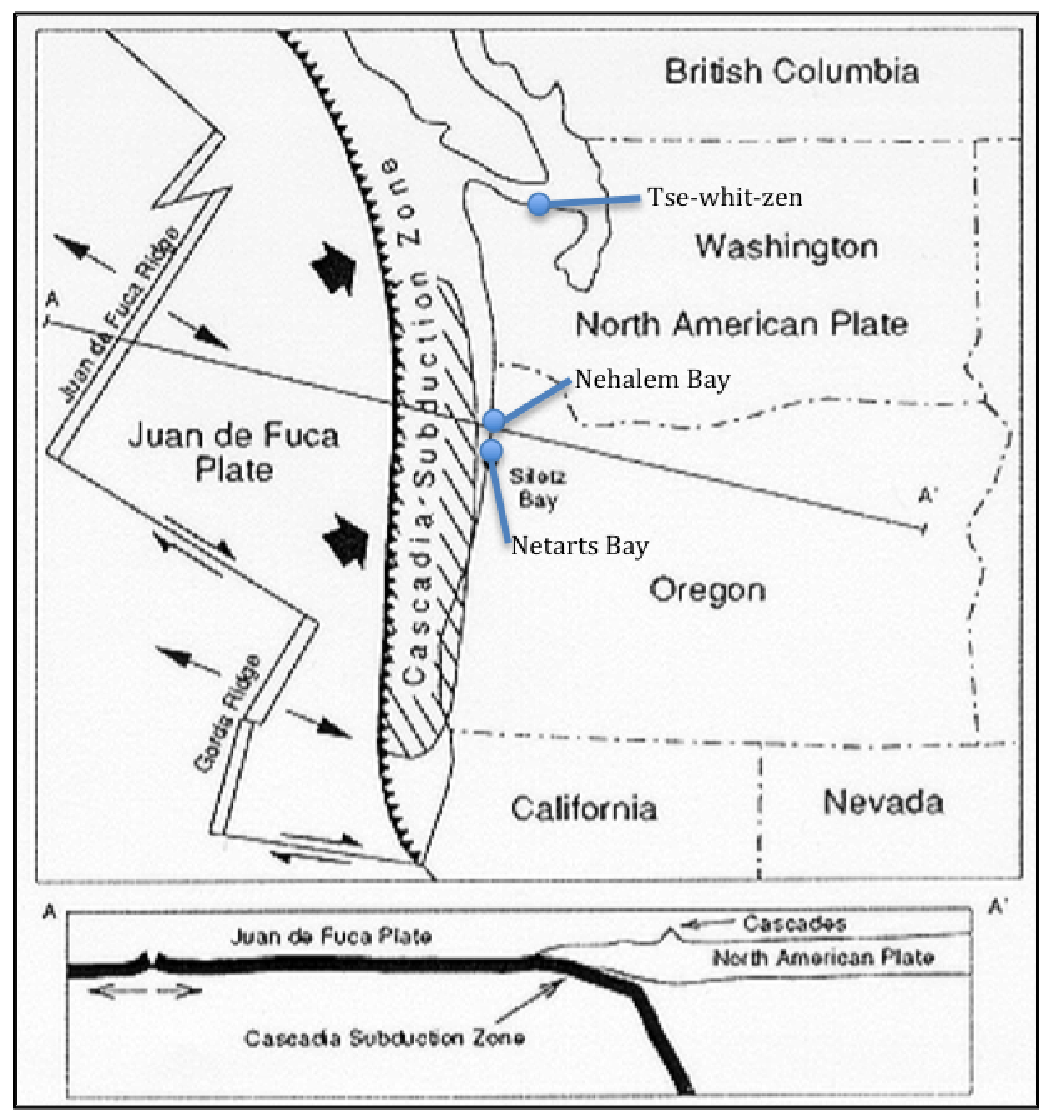

Figure 1.1: Cascadia Subduction Zone boundary with site locations (modified and used with kind permission from the Oregon Department of Geology and Mineral Industries 1995)

Previous examinations into the archaeology of disaster response suggest communities suffered significant stress, community restructuring, and/or settlement abandonment after an event (e.g. Hutchinson and McMillan 1997, Tveskov and Erlandson 2003), highlighting the vulnerability of human groups to the effects of abrupt environmental change. Such evidence has been documented both in the Northwest Coast region (e.g. Hutchinson and McMillan 1997, Losey 2002, 2005), and worldwide (e.g. papers in Reycraft and Bawden 2000, Goff and McFadgen 2001 and 2003, Stiros 2001, Saltonstall and Carver 2002, Torrence and Grattan 
2002, Grattan and Torrence 2007). Due to the extended time depth available in the archaeological record, archaeology is the ideal arena in which to study human response to abrupt environmental events of the past and the vulnerability and resilience of coastal societies to these events.

Despite this, documenting human response to catastrophic events archaeologically is challenging. The coarse resolution of the archaeological record in most sites prevents the tight linkage of environmental and cultural events, because of the nature of preservation or excavation techniques (Sterling et al. 2011). Wellresolved chronologies may exist for environmental events and even cultural processes such as house construction, but these timelines are difficult to overlay because they are based on differing time scales. A site with specific qualifications is necessary to address human response to abrupt environmental change: it must possess a lengthy occupational history, have a well-resolved temporal sequence through control over site formation, and be located where several different catastrophic events could be identified within the stratigraphy.

The site of Tse-whit-zen, on the Olympic Peninsula of Washington State, USA, presents a rare opportunity to study this linkage (Fig 1.2). Several plankhouses spanning about 2000 years of occupational history were excavated here in 2004. The site was excavated with fine stratigraphic control, allowing for precise comparison of the natural and the cultural record. The occupational record spans four known seismic events (Sterling et al. 2006), presenting an opportunity to address questions of human response to catastrophic events originating at the CSZ. 


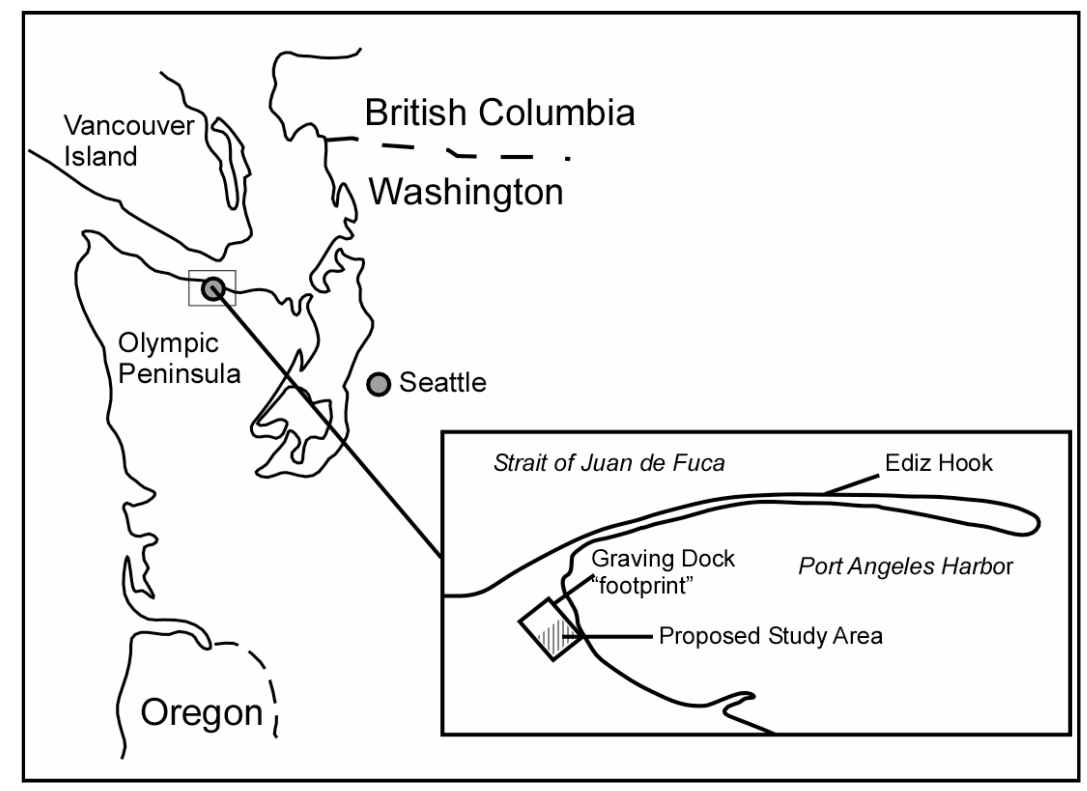

Figure 1.2: Regional map showing the location of Port Angeles on the Olympic Peninsula of Washington State, as well as the location of Tse-whit-zen on the base of Ediz Hook west of Port Angeles, WA (from Sterling et al. 2011)

Furthermore, the massive amount of faunal material excavated at the Tsewhit-zen site presents an ideal way to approach questions of human responses by attempting to understand the responses of key animal resources to catastrophic events (Losey 2002, 2005). A subsistence strategy focused primarily on the marine environment is evident here through the large abundance of fish and shellfish remains recovered. These marine resources were likely the most vulnerable to CSZ coseismic events due to their specific habitat requirements in an environment susceptible to tsunami damage (Losey 2005). Therefore, studying marine resource abundances at Tse-whit-zen over time should provide clues to the vulnerability of marine resources to catastrophic events. 


\section{Research Scope and Questions}

In this thesis research, a pilot project that is part of a larger NSF-funded project, I assess the response of fish resources to abrupt environmental change at Tse-whit-zen by examining an assemblage of fish remains recovered from a $2 \times 2 \mathrm{~m}$ unit associated with one occupation structure. These responses may be reflected in the changes in relative abundances of different fish taxa over time, especially after an earthquake and tsunami event. This examination will not only clarify prehistoric presence of fish taxa in the Strait of Juan de Fuca region and inform upon past Native fishing practices, but will also assess the impact of abrupt environmental events on the Native inhabitants of Tse-whit-zen, addressing the larger topic of human vulnerability to catastrophic events.

In addition to this important area of research, this work has modern utility. The extended time depth of this site allows a more detailed understanding of the dynamics of marine fisheries over time usually not available to modern fisheries biologists and conservationists. Therefore, it will provide a detailed record of fish use on the Olympic Peninsula that could be used by modern fisheries biologists for habitat reconstruction: this is of great importance currently given the recent series of dam removals on the Elwha River, which drains into the Strait of Juan de Fuca about $10 \mathrm{~km}$ west of the site (Wunderlich et al. 1994, Bednarek 2001, Gregory et al. 2002, Gowan et al. 2005, Pess et al. 2008).

I will address a variety of questions through this analysis: What fish species are present? How specialized or generalized was the fishery? Overall, how do 
relative species abundances change over time? What is the response of fish species to a catastrophic event? These questions help address the dynamics of the fishery at Tse-whit-zen over time, and can be answered due to the large number of fish remains excavated with fine stratigraphic control, as well as an extensive radiocarbon chronology already available for the site.

This thesis is organized into six chapters. Chapter two outlines the environmental context, traditional lifeways and resource use of peoples of the Northwest Coast, situating Tse-whit-zen in a broad environmental and cultural context. I review previous research pertaining to human response to catastrophic events, with focus specifically on animal vulnerability and responses to earthquake and tsunami events. Background information for the site of Tse-whit-zen, including excavation information, chronological control of the site, and the nature of the faunal assemblage are also outlined in this chapter. Chapter three reviews the materials and methods for identification and analysis of the assemblage. Chapter four outlines the results of the examination, and includes a descriptive summary of the taxa present in the assemblage. Chapter five presents a discussion of these results with specific focus on fish response to tsunami events, and in turn, I discuss the possible impacts on the human population of Tse-whit-zen, assessing their vulnerability and resilience over these abrupt events. Chapter six presents conclusions to this research and suggestions for further work. 


\section{Background}

\section{CSZ environmental overview}

Tse-whit-zen is located on the northern shore of the Olympic Peninsula, on the western edge of Port Angeles in Washington State, USA (Fig 1.2). This region is situated along the CSZ (Fig 1.1), where the thin Juan de Fuca plate, located offshore of Oregon and Washington States and Vancouver Island of British Columbia subducts underneath the thicker North American plate. This zone spans from the Copper River delta in Alaska to near Cape Mendocino in California (Atwater 1987, Losey 2002); the plate boundary comes to the surface about $80 \mathrm{~km}$ offshore of Washington (Guidoboni and Ebel 2009).

Until the 1980s, researchers believed the CSZ was aseismic, differentiating it from other parts of the North American coast (California, Alaska). The first clue that the CSZ was indeed capable of generating massive earthquakes came from geological evidence within estuarine sediments in southwest Washington (Atwater 1987). Since then, researchers have used geological and geophysical evidence from continental shelf stratigraphy (Adams 1990, Goldfinger et al. 2003), marshes (Hemphill-Haley 1995), tidal wetlands (Jacoby et al. 1997, Satake et al. 2003, Peterson et al. 2012), and coastal forests (Benson et al. 2001) to argue for the cyclical recurrence of great earthquakes (moment magnitude > 7.5), capable of rupturing much of the CSZ every 500-1000 years (e.g. Atwater 1987, Atwater et al. 2004, Satake and Atwater 2007), over the last 7000 years. Along with more local 
geomorphological changes, these seismic events may have greatly affected the landform and human occupants, including structures and toolkits, at Tse-whit-zen multiple times over the course of occupation (Sterling et al. 2006). Possible impacts could have included ground shaking, coseismic uplift or subsidence, and/or tsunami surges scouring the nearshore habitat and inland.

Four great earthquakes have been documented for the Olympic Peninsula spanning the last 2000 years: Event S, occurring between 1700 and 1500 years ago, Events U/W, two earthquakes geologists have dated between 1400 and 900 years ago (Williams 1999), and Event Y, dated to AD 1700 corroborated by Japanese records of an "orphan" tsunami (Atwater et al. 2005). These events have been documented repeatedly by evidence from turbidity currents and the presence of tsunami sands on Southern Vancouver Island and Northern Washington (Sterling et al. 2006, Peterson et al. 2012). They also overlap with the time period Tse-whit-zen was occupied, estimated from 1824-54 cal BP. While direct evidence for subsidence and tsunamis has not been documented at the site, geoarchaeologists at Tse-whitzen identified anomalous transgressive episodes in the overall emergent character of the beach, finding evidence of truncated berms and buried swash deposits on otherwise stable berm features (Sterling et al. 2006). Additionally, Sterling et al.'s (2011) study of organic matter, phosphorous, and radiocarbon records suggest patterning in cultural occupation that correlates with the four great earthquakes. This evidence strongly suggests the people of Tse-whit-zen, and the resource base on which they relied, were affected by these events. 
Tse-whit-zen in Cultural Context

The richness of the marine environment off of the Northwest Coast, combined with human-driven intensification and storage traditions, allowed this region to be home to an exceptionally dense population. Archaeological and ethnographic evidence illustrates the ubiquity of large, coastal villages comprised of multiple plankhouses (Matson and Coupland 1994, Ames and Maschner 1999) arrayed all along the coast. Villages were situated on the shoreline, with the houses arrayed in one or two rows, usually on beach ridges or sandspits (Losey 2002) on a bay or estuary (Ames and Maschner 1999). This orientation allowed for maximum use of the marine and nearshore environment, though a reliance on the terrestrial environment was also variably important in different parts of the coast. Travel and resource procurement were accomplished primarily by boat (Ames and Maschner 1999, Ames 2002), illustrating the need to invest a large amount of capital in building and upkeep of this equipment.

In addition to boats, communities invested extensively in technology to augment the harvest of marine resources (Tveskov and Erlandson 2003) and to take advantage of short seasonal abundances (e.g. large salmon runs) (Suttles 1990). Plankhouses were the principal food-storage areas for the residents. Important dried food sources such as dried salmon and other fish, cured whale, seal, and sea lion blubber and oil, and dried berries that were vital for winter survival were stored in the houses (Drucker 1965). Ethnographic and archaeological evidence indicates that groups including the Makah on the Olympic Peninsula (Swan 1869), the Nuu- 
chah-nulth on Vancouver Island (Arima 1983, McMillan 1999), and the Coast Salish on the Salish Sea (Suttles 1974) among many others, all engaged in intensive harvest of coastal and terrestrial resources, storage, and trade.

\section{Abrupt Environmental Change and Marine Resources}

The resilience of the crucial economic resources outlined above would in part determine the vulnerability of Native communities to abrupt environmental change. One way to make predictions about the ecological impacts of a coseismic event on local animal resources is to use recent and/or historic earthquakes in coastal environments as analogs, though difference in coastal morphology and bathymetry could create varying tsunami hazard along different parts of the coast (Hutchinson and McMillan 1997). While effort has been put into studying the immediate effects of coseismic events on coastal human populations, little attention has been devoted to understanding long-term ecological changes following an event in the CSZ.

The CSZ has not produced an event since the time of European contact in the early 1800 s, precluding use of historic written records to understand ecological impacts. Losey $(2002,2005)$ notes the 1964 Good Friday earthquake that originated at the Aleutian-Alaskan Subduction zone and affected Prince William Sound and the area around Anchorage, AK, as the most useful analog to an earthquake originating at the CSZ since there were many similarities in the overall morphology of the coast and marine environment. It achieved a 9.2 moment magnitude, generated a massive tsunami, and caused uplift and subsidence all along the coastline (Losey 2005). 
Geologists and biologists carried out multiple studies to measure these impacts in the few years following the event (e.g. National Academy of Sciences 1971). However, these studies were focused on only a few key economic resources, so the time required for many resources to fully recover remains poorly understood (Losey 2002, 2005, Saltonstall and Carver 2002).

Immediate impacts on mussels and other bivalves, salmon, and other marine species were reported, showing relatively minor loss of numbers and habitat. Considerable attention was focused on economically important pink (Oncorhynchus gorbuscha) and chum (O. keta) salmon over several years after the event as well. The earthquake negatively affected these resources, though total loss was relatively small and some positive impacts were reported also. Salmonids spend a majority of their adult lives out to sea, far away from any effects of a tsunami (Hart 1973, Losey 2002). Only the group that was congregating in the nearshore environment to run up natal streams, as well as the salmon eggs and alevins in the streams, would be at risk during the actual event. Losey (2002) reports one-quarter of a million salmonids (no species indicated) were estimated to have died during the 1964 event. However, up to 3.6 million salmon spawn in rivers draining Prince William Sound alone every year (Stanley 1968): the overall loss to the fishery therefore was minor.

At a smaller geographic scale, the losses were more variable. Losey (2002) reports that in the years following the event, salmon migration up some streams in the area dropped between $40 \%$ and $98 \%$, though some of these "lost" salmon moved 
to newly created salmon streams. It is also noteworthy that subsided streams lost only around $8 \%$ of their migrating population. Overall, the 1964 event created some new habitat for salmonid spawning grounds, and subsided areas did not suffer as severely (Losey 2002). Since the smaller geographic scale shows severe losses in some affected areas, however, hunter-gatherers relying on local salmon runs could have suffered major losses; the impact of the earthquake on these peoples could have been more profound.

Another study following the 1964 earthquake was conducted to understand recolonization of eelgrass beds (Zostera spp.), which are a vital aspect of the nearshore habitat and diet for many ecologically important fishes such as herring (Clupea pallasii) small species of sculpins (Cottidae), and tomcods (Microgadus proximus) along the Alaskan shoreline and the CSZ as well (Schultz 1990, Byram 2002). Eelgrass beds colonize muddy sandflats in the lower intertidal to subtidal areas (Schultz 1990), and therefore would be susceptible to tsunami damage via scouring. Hanna (1966) reports, however, that eelgrass beds were recolonizing uplifted areas only a year after the event. Also, Losey (2002) notes that eelgrass beds lose about $75 \%$ of their biomass annually due to grazing and yet rebound. It is likely, if any eelgrass survived the impacts of the coseismic event, that eelgrass beds in the CSZ would have rebounded quickly.

This historic record is valuable as a starting point in understanding the intensity of losses to both fish species and their habitats, but the view from the 1964 post-earthquake studies is that losses would be minimal and fish taxa and their 
habitats were and are resilient to coseismic events. It is important to note this is only a small picture of total impacts; many other important ecosystems are not discussed in this report. For example, the mid-water region slightly off the coast hosts large kelp forests. These forests need a rocky substrate in which to attach in order to grow, and are home to a variety of fish taxa like Pacific cod (Gadus macrocephalus), red Irish lord (Hemilepidotus hemilepidotus) and other large sculpins, and juvenile sablefish (Anoplopoma fimbria). The destruction of these forests could create a long-term problem for the local fish species, and may be less resilient to these catastrophic events than the above examples. Additionally, freshwater salmon streams could also take multiple years to return to the specific conditions needed for salmon to spawn, including proper salinity levels, silt content, and water temperature (Losey 2002). The above resources with longer recovery times highlight the data gaps in the post-earthquake report. Some resources may be resilient to coseismic events, but the variation in resiliency across resources could be pronounced.

More extensive losses in marine species have been seen in other parts of the world following recent earthquakes, further illustrating this variability in response. The 2004 Indonesian tsunami that affected the coastlines of Southeast Asia provides some additional examples of impacts on economically important fisheries. The Food and Agriculture Organization (FAO) assessed damage to fisheries and coral reefs off the coasts of India, Myanmar, and Sri Lanka, finding that local fish populations were 
devastated, along with dependent food webs including coastal human populations reliant on the fishing industry for their livelihood (FAO 2005).

In a report assessing the damage to 2004 tsunami-affected ecosystems in the Nikobar Islands (located in the Indian Ocean), Ramachandran et al. (2005) discussed the importance of understanding the level of destruction of key coastal ecosystems, including mangrove swamps, coral reefs, estuarine mudflats, and sea grasses. As an example, they report the extent of coral reef damage in ecosystems surrounding these islands ranged from $41 \%$ to $100 \%$. Though the coral reefs make up less than $1 \%$ of the marine ecosystem surrounding these islands, they are home to over $25 \%$ of all fish species, and are extremely important locations for local fishers due to the density of fish resources there (Ramachandran et al. 2005). Again, the removal of these resources due to the destruction of the reefs had a direct effect on rural residents' livelihoods.

The differences in these records compared to those from the 1964 Alaskan earthquake show how variable the impacts on marine resources and their dependent food webs can be. This variability, coupled with the differences in coastal morphology along other coastlines and incomplete reporting, illustrates why modern analogs must be used carefully in interpreting prehistoric events. Study of these modern records do however suggest the fisheries off the CSZ faced some losses as a result of coseismic events in more ancient times, which could be detected in the archaeological record. 


\section{Archaeological evidence}

Though the study of human responses to catastrophic events has been undertaken worldwide (e.g. papers in Reycraft and Bawden 2000, Torrence and Grattan 2002, Grattan and Torrence 2007), few studies directly address how these events, including coseismic events, would have affected animal populations and other subsistence resources. Robert Losey's (2002) study of the vulnerability of the Tillamook people to the AD 1700 coseismic event is one of the few that directly uses zooarchaeological evidence linked with tsunami deposits to study marine resource vulnerability and in turn human responses. Often, changes in resource use are assumed as part of the human response to coseismic events (Goff and McFadgen 2003, Losey 2005).

In order to interpret human and animal vulnerability on the Oregon coast to the most recent CSZ earthquake event, Losey $(2002,2005)$ used the 1964 Good Friday earthquake as an analog. He also used previous and current archaeological excavations on two different areas of the coast, Netarts and Nehalem Bays (Fig 1.1), which were inhabited by the Tillamook people, to assess human and animal vulnerability and resilience to these events. The results and interpretations from Losey's study served as a model for developing my archaeological expectations. Losey (2002) analyzed numerous previously excavated sites in Nehalem Bay, including the Cronin Point site (35-TI-4), the Spruce Tree site (35-TI-75), and the North Trail House site (35-TI-76). All of these sites were initially excavated in the 1980s (Woodward 1986), and were described in very little detail; little is known 
about the nature of the faunal collections from these excavations. Losey returned to all three locales and conducted further testing to relocate and map the sites, excavate test units to collect more cultural material, and gather samples for radiocarbon dates (Losey 2002). He studied fish remains from contexts dating before and after the AD 1700 coseismic event. The sample sizes were small and in very poor condition; Losey reports that the excavated assemblages were comprised mostly of salmon vertebral fragments. Indeed, the only identifiable bones in the entire assemblage were salmon vertebrae, suggesting that this assemblage does not reflect the full spectrum of animal use in this bay. All bone material was fragmented and chalky (Losey 2002: 528). In these conditions, small-bodied fish bones could have degraded much more quickly than larger salmon vertebrae. Furthermore, salmon can be over-represented in assemblages because their vertebrae are easily identifiable, even if highly fragmented (Casteel 1976: 90-92). These factors could have led to a bias in the assemblage toward salmonids.

Losey's fish analysis at Nehalem Bay is limited therefore to salmonids, which he claims suffered a minor impact from the AD 1700 earthquake. The change through time of fish use can be tracked at the North Trail House site alone because it is the only site of the three that has a clear pre-1700 occupation component. This site shows no obvious gap in occupation, and the resource base does not appear to have shifted greatly. He found, through radiocarbon dating and presence of $19^{\text {th }}$ century artifacts, that all three Nehalem Bay sites show evidence of occupation after 
the AD 1700 event. The post- 1700 occupation components at all sites suggest no large coseismic impact on this bay or its people.

The fish remains from Netarts Bay were in better condition, and can more concretely provide information about human responses to the AD 1700 event. Losey focused on previous excavations at 35-TI-1, the Netarts sandspit village, to interpret human and animal vulnerability, with a small discussion of other sites on the bay as well. The excavations of the sandspit village took place in the 1950s (Newman 1959); screening was not consistently done. Therefore, smaller bones (including many fish bones), if present, were not collected, and analysis of what faunal remains were collected was not done systematically (Losey 2002: 192). In 1999, Losey returned to the site, excavated four test pits and screened all matrix through 3.35 mm (.132 ") mesh, giving a much more complete picture of faunal use in this village. Additionally, lab processing of bulk samples used $2 \mathrm{~mm}$ mesh screens as the smallest fraction. Twenty-three radiocarbon dates obtained in Losey's reanalysis of the site indicate that at least one structure at 35-TI-1 was inhabited after the AD 1700 CSZ earthquake event, possibly as late as AD 1800 (Losey 2002: 258). Some of these structures were only about $15 \mathrm{~m}$ from the shoreline (Losey 2002), and therefore were vulnerable to the full impact of a tsunami wave.

Analysis of $\sim 67,000$ faunal remains allowed him to interpret changes in relative species abundances before and after the AD 1700 earthquake. The preearthquake assemblage showed a typical focus on many small estuarine fish, such as surfperch (Embiotocidae), herring (Clupea pallasii), sardine (Sardinops sagax), and 
small sculpins (Cottidae), and larger fish including starry flounder (Platichthys stellatus), salmon (Oncorhynchus spp.), and hake (Merluccius productus), as well as a wide variety of shellfish, pinnipeds and sea otters, deer and elk, and aquatic birds. Post-earthquake, the inhabitants shifted their resource base. In terms of fish, the relative abundances of smaller species (surfperch, sculpins, herring) increase when compared to larger species, such as flatfish (halibut, starry flounder) and salmon (Losey 2002: 297-298). He speculates this change could be due to the ability for smaller species associated with eelgrass habitats to rebound more quickly than larger fish associated with a range of habitats. As noted above and drawing on the 1964 earthquake records, Losey highlights that eelgrass can recolonize an area quickly. Since smaller species live and reproduce in eelgrass, fish populations linked to this environment would have been more resilient compared to other species. Alternatively, he discusses the possibility that the bay inhabitants could have lost their resource gathering equipment, such as boats and fishing gear. Without these, it would have been much more difficult or impossible to procure offshore fish associated with the bottom, mid, and surface waters.

Overall, he concludes the inhabitants of Netarts Bay and the surrounding ecosystem were little affected by the 1700 event. The bay was not completely abandoned and people continued to make a living from this estuary, though the changes in resource use (size of fishes, as well as a shift to more terrestrial mammals) may have signified a forced change in procurement strategy. He cautions that many other factors could be responsible for changes in subsistence at the site 
that have little to do with coseismic events, but ultimately links the shifts in resource use he sees to the coseismic event.

Very few case studies of animal response to earthquake events using zooarchaeology have been carried out, in the Northwest Coast or elsewhere in the world. The work that has been done highlights that though inhabitants appeared to live in exposed areas and subsisted on resources that may have been vulnerable to coseismic impacts, the continuity of occupation at these sites demonstrates some resilience to coseismic events. However, several limitations to these studies, coupled with the difficulty of understanding short-term temporal events in the archaeological record, reinforce the need for more work in this research area. Using these previous records, I now turn to the village of Tse-whit-zen on the Olympic Peninsula in order to assess the potential impacts of earthquakes on the aquatic resources of the Strait of Juan de Fuca.

\section{The Value of the Tse-whit-zen Site}

The village of Tse-whit-zen (45CA523) provides a unique opportunity to assess impacts of abrupt environmental change on the natural resources of the CSZ. The village site is located in the territory of the Salish speaking Klallam people, and is a traditional village of the Lower Elwha Klallam Tribe (LEKT). It lies at the western edge of Port Angeles, Clallam County, Washington, at the base of a sandspit called Ediz Hook that projects out into the Strait of Juan de Fuca (Fig 1.2). It sits on a series of beaches that prograded into the bay, now Port Angeles harbor, as the 
sandspit developed (Sterling et al. 2006). This sandspit facilitated shoreline growth even after sea level stabilization, which occurred about 5000 years ago, and allowed the development of sheltered, stable landforms suitable for permanent human occupation (Sterling et al. 2006). The proximity to the west and southwest of a tidal marsh and lagoon would have given further access to marine resources, as well as a sheltered area to store boats, creating an ideal location for a hunter-gatherer village (Sterling et al. 2006).

While my main goal will be to study fish response to catastrophic events at Tse-whit-zen, there are several additional benefits to this study as well. My work will expand our knowledge of Native American fisheries from the Olympic Peninsula region, providing useful comparisons with fish bone records from the nearby sites of Hoko River (45CA213) and Ozette (45CA24). Additionally, this data set may assist current fisheries management and conservation (Moss 2011: 137). For example, expanded knowledge of the salmon fisheries obtained through this research may aid salmon habitat restoration and the reestablishment of the large salmon fishery that should accompany the ongoing removal process of the Elwha River dams (Wunderlich et al. 1994, Bednarek 2001, Gregory et al. 2002, Gowan et al. 2005, Pess et al. 2008).

Environmental Setting of Tse-whit-zen

The waters of the CSZ provide an extremely productive environment due to the prevalence of two atmospheric pressure cells: the North Pacific High and the 
Aleutian Low (Thomson 1981). In summer, the North Pacific High moves over the region and causes northwest winds to generate a southbound flow of colder, Northern Pacific water that collides with the continental shelf and causes an upwelling of nutrients and oxygen (Thomson 1981). This creates a period of extreme biological productivity that in turn provides food (e.g. copepods, zooplankton) to support an abundance of marine life, including a large variety of pelagic fish species, marine shellfish, sea birds, and sea mammals (Campbell and Butler 2011). Many of these resources could have been accessed in close vicinity to Tse-whit-zen.

This large variety of fish resources is found in several habitat types, all of which could have been accessed by fishers from the village. For example, many species of bottom-dwelling reef fish live in areas of rocky substrate and kelp forest, including species of sculpins and Pacific cod (Gadus macrocephalus). More shallow water, sandy substrate, eelgrass habitat is ideal for smaller species of cottid and flatfish (Pleuronectiformes). Additionally, species of schooling fish, such as herring, frequent the nearshore areas seasonally. Offshore and nearshore, larger species, such as spiny dogfish (Squalus acanthias) are common (Hart 1973). Salmon would have been available in the Elwha River, $\sim 10 \mathrm{~km}$ from the village. Seasonally, five species of anadromous salmonids migrate up this and other area rivers, providing massive seasonal abundances that were a staple resource for many coastal groups, according to both the ethnographic and the archaeological record (e.g. Gunther 1927, Suttles 1990, Huelsbeck and Croes 1980, Campbell and Butler 2011). 
In addition to these local fish resources, plants, marine shellfish (e.g. mussels [Mytilus spp.], sea urchin [Strogylocentrotus spp.], chitons [Chitonidae] [Kozloff 1973]), terrestrial (e.g. deer [Odocoileus spp.], elk [Cervus elaphus]), and marine mammals (e.g. sea lion [Otariidae], harbor seal [Phoca vitulina], sea otter [Enhydra lutris]) and waterfowl (e.g. multiple species of ducks and geese [Anseriformes], grebes [Podicipedidae], sandpipers [Scolopacidae]) all played a role in the diet of the Klallam people (e.g. Croes and Blinman 1980).

\section{Excavation of Tse-whit-zen}

The Tse-whit-zen site was excavated as part of the Washington Department of Transportation (WSDOT) Port Angeles Graving Dock Facility Project. This facility was intended to provide an area to build large pontoons to aid the replacement of the Hood Canal Bridge (Larson 2006). After many months of disagreement about the nature of the site based on the presence of an ethnographic Klallam village near the area of potential effect (APE) and the discovery of human remains by archaeological monitors in construction trenches, the Lower Elwha Klallam Tribe (LEKT) and Larson Anthropological Archaeological Services, Incorporated (LAAS) developed a field program to delineate site boundaries and determine true significance of this APE.

WSDOT contracted LAAS to begin a full data recovery excavation in April 2004, which was undertaken by archaeologists from LAAS in close conjunction with LEKT members. This massive undertaking (Fig 2.1) benefitted from LEKT support 
and participation; tribal members helped in screening and excavation, as well as many other areas of the project (Larson 2006, Reetz et al. 2006).

Data recovery was conducted within $1 \mathrm{x} 1 \mathrm{~m}$ units grouped into blocks in order to obtain horizontal exposures and to facilitate the removal of human remains (Lewarch and Larson 2004). Though the original treatment plan estimated excavating about $6 \%$ of an estimated $2913 \mathrm{~m}^{3}$ cultural material, the actual excavation removed about $4 \%$ of the $6900 \mathrm{~m}^{3}$ revised estimated site volume, 261.4 $\mathrm{m}^{3}$.

Excavation was undertaken following natural strata and was only subdivided into $10 \mathrm{~cm}$ arbitrary levels when the stratum exceeded this thickness. In a single block, when possible, archaeologists excavated down to the same stratigraphic level or elevation in order to expose a common surface. This was necessary in order to establish contemporaneity of different features, of which over 1400 were excavated (Larson 2006). Seven major stratigraphic units were identified (Reetz et al. 2006:430). The strata labeled 3 and 5 were the major occupation matrix comprised of archaeological midden deposits. Strata labeled 6 and 7 were the underlying beach sands that provided a foundation for the village occupation. 


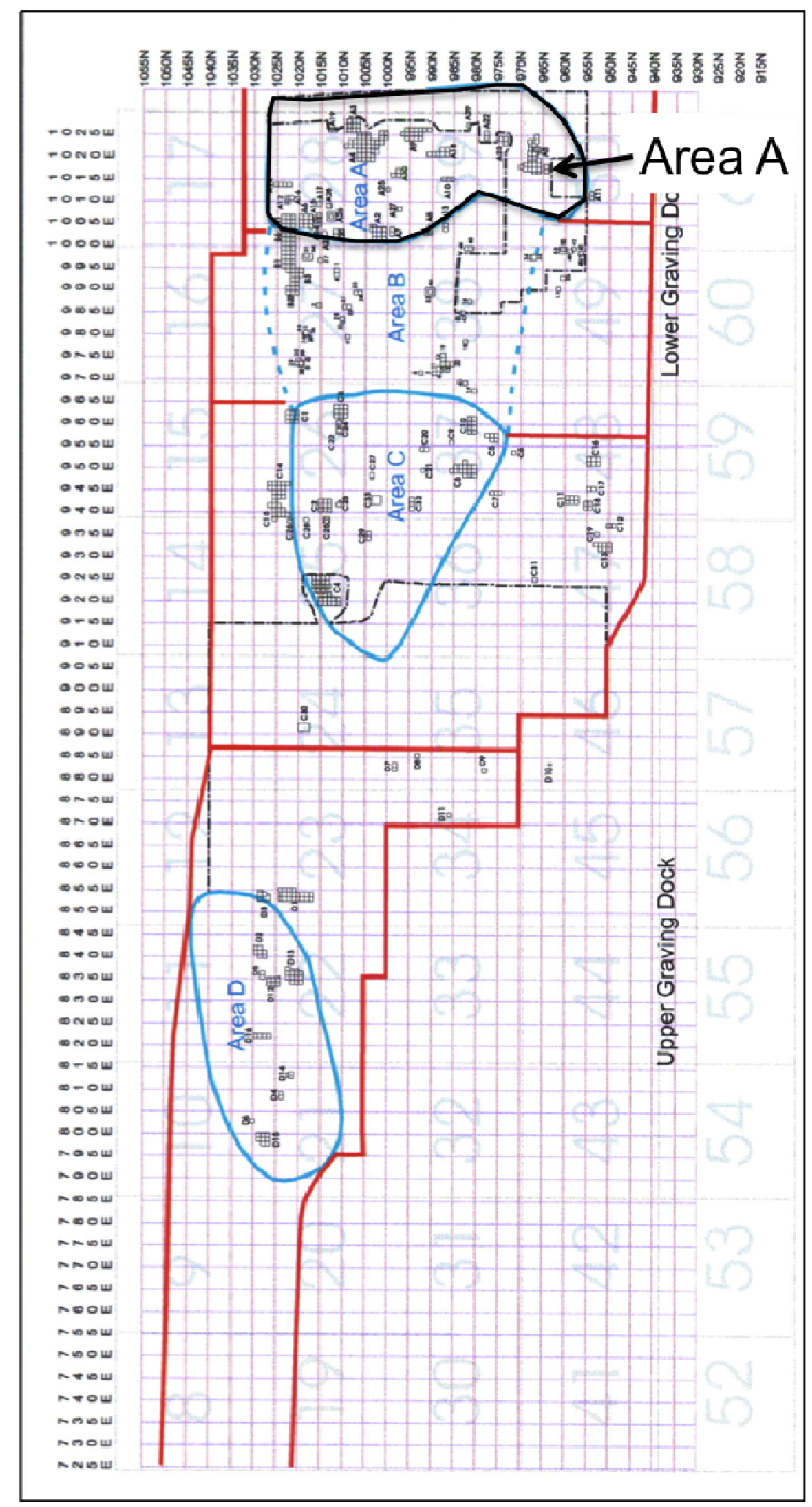

Figure 2.1: Site map of Tse-whit-zen excavation areas (Reetz et al. 2006, 4-3) 
In order to estimate volume and set aside a sample for studying all faunal taxa, excavated matrix was placed in $10 \mathrm{~L}$ buckets and then brought to the water screening station. Every $20^{\text {th }} 10 \mathrm{~L}$ bucket from a given stratum was marked as a "complete" bucket. The water screening station used a series of nested screens; all material was deposited in the 1" screen and subsequently screened through $1 / 2$ ", $1 / 4$ ", and $1 / 8^{\prime \prime}$ screen size fractions as well. Problems with the screening process were discovered later, however, and are discussed below. Use of fine mesh screens such as 1/8" (or even smaller), is ideal for recovering a representative sample of faunal material, including small-bodied fish such as herring (e.g. Casteel 1972, 1976, Partlow 2006).

In December 2004, because of the excavation of over 300 intact burials and archaeological costs soaring over budget, WSDOT decided to stop work at the site in favor of finding a new location for the graving dock facility. Only preliminary laboratory sorting was accomplished to separate classes of materials (e.g. lithics, modified bone, non-human bone) due to the abrupt ending of the project.

My thesis is focused on one 2x2m unit in Area A4 (Fig 2.2), a section of Area A, which had an estimated site volume of $1900 \mathrm{~m}^{3}$; the largest area excavated in the site (Reetz et al. 2006). The excavation area of Area A was about 35 x 93 m; 80\% of this area was undisturbed and held intact burials. This area held a rich array of structural and thermal features, fishing gear, and massive abundances of faunal material (Reetz et al. 2006:4-31). 
In order to establish methodology and protocols for the larger NSF project, a pilot study was developed which represents my thesis research. This unit was chosen because the cultural layer in A4, associated with Structure 1, was thicker than anywhere else in the site, with a maximum thickness of $147 \mathrm{~cm}$, encompassing 1800 years of occupation based on $19{ }^{14} \mathrm{C}$ dates (1824-252 cal years BP) (Reetz et al. 2004:4-38). This unit was also selected because it yielded large samples of each class of faunal material, which would provide the opportunity to compare analytic results across faunal classes before undertaking the NSF project. 


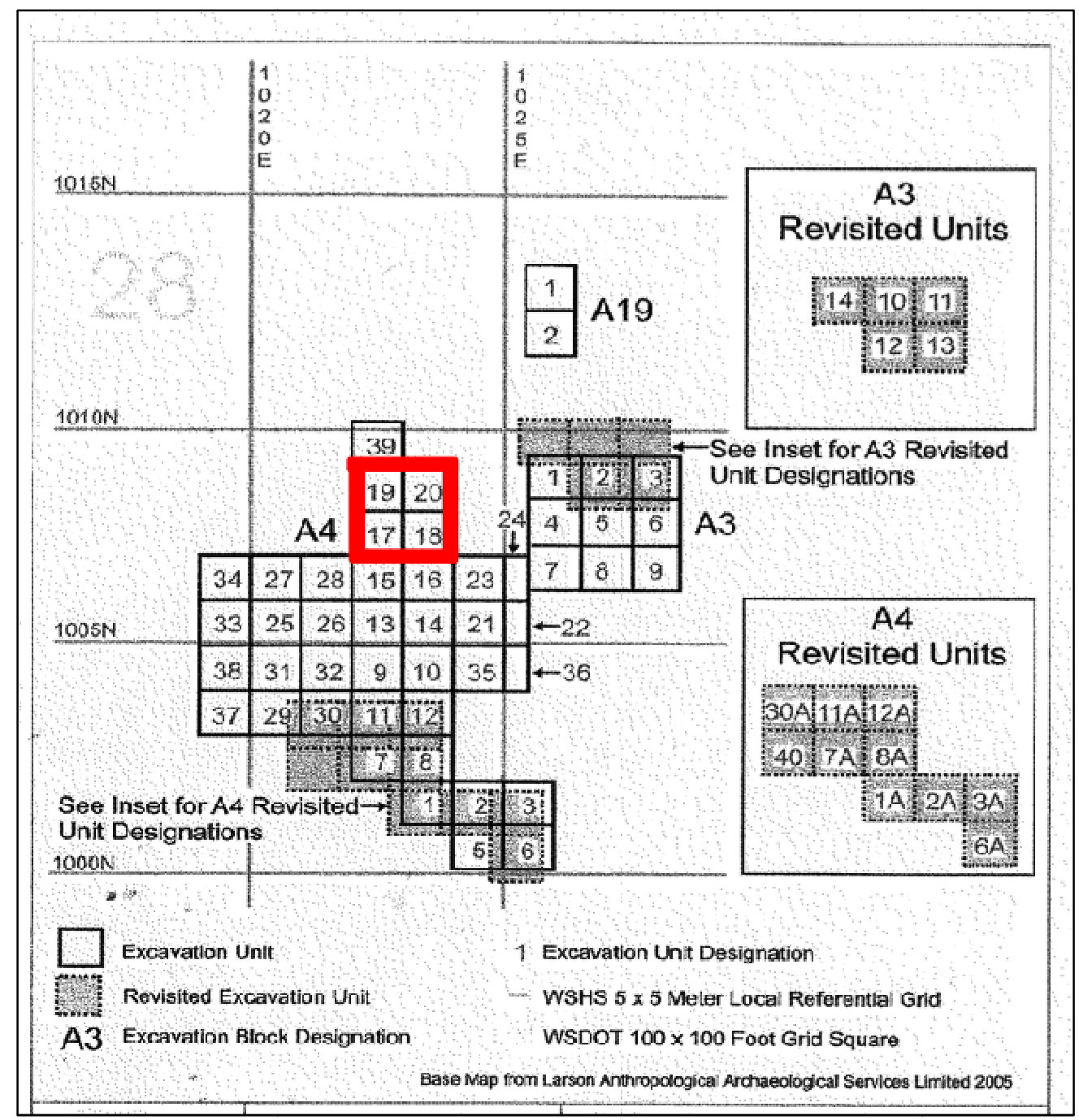

Figure 2.2: Area A4 of the Tse-whit-zen excavation with thesis (pilot) units highlighted in red (Larson 2006)

Seven analytic zones have been defined for this $2 \times 2 \mathrm{~m}$ unit (Units 17-20) based on analysis of depositional contexts and stratigraphic relationships (Fig 2.3) (Sterling et al. 2013). The lower component is separated into three zones, identified by three terminal surfaces (A4.07, A4.06, A4.05). Terminal surfaces were defined during excavation as strata thought to represent living floors due to their dense compaction. A palimpsest of cultural material including fish bone, shell, charcoal and 
other material reflected long-term use of the floors, and were used to infer the presence of structures (Sterling et al. 2006: 7-12). The upper component represents the presence of Structure 1, and is broken into two contexts. The upper component of units 17 and 19 is associated with an entry way of the structure, while units 18 and 20 are situated exterior to the structure. This difference in context is reflected by a different analytic zone assignment (A4.01 and A4.02: entry way, A4.03 and A4.04: exterior).

Five radiocarbon dates from the $2 \times 2 \mathrm{~m}$ unit and adjacent contexts suggest the lower component dates to between 1000 and 1250 B.P. and the upper component to 520 to 770 B.P. (ages uncalibrated) (Sterling et al. 2013). These dates suggest a $\sim 300$ year occupation gap between the two components. 


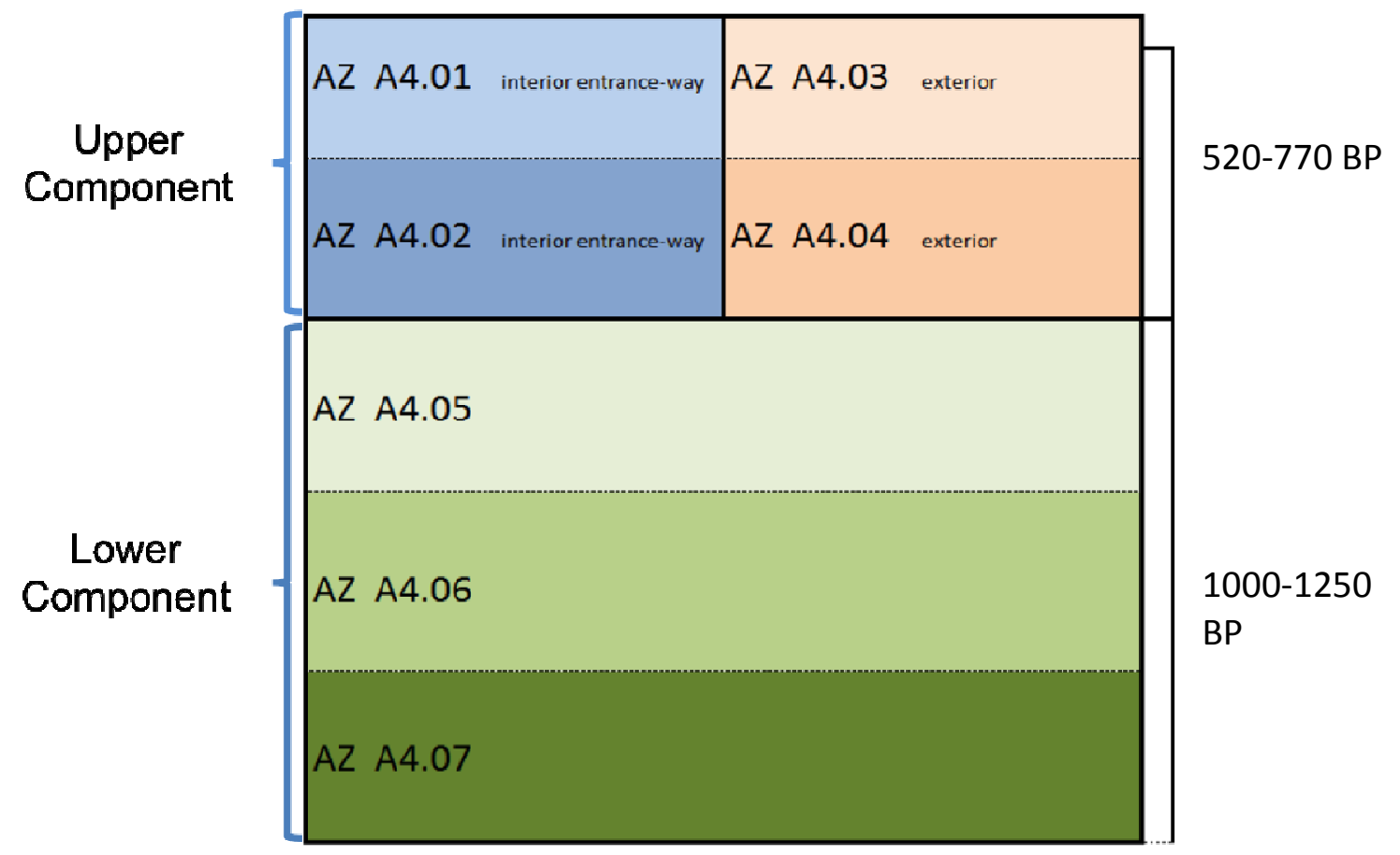

Figure 2.3: Assignment of analytic zones for the $2 \times 2 \mathrm{~m}$ pilot unit in Area A4

\section{Taxonomic Identification Issues}

A central goal of most zooarchaeological study is to characterize the relative economic importance of different taxa (e.g. Grayson 1984, Lyman 2008) in order to create a record of subsistence practices and human-animal relationships over time and space. Before these interpretations can be made, however, the effect of taphonomy, recovery, and quantification on the assemblage must be understood. Without this context, it is likely that taxonomic representation and abundance could be driven by post-depositional or analytical processes as opposed to actual relationships between humans and animals. Understanding recovery issues such as excavated volume and mesh size, and the effect of different grouping and 
quantification methods, is necessary before interpretations can be made from any faunal assemblage.

Excavated Volume and Sample Size

It has been shown (Grayson 1981, Lyman 1995, Lyman and Ames 2007, Lyman 2008) that increasing excavated volume has a direct effect on the sample size and richness for an assemblage. Rare taxa are often missed in small samples; the odds of encountering these rare taxa increase as sample size increases until one begins to "sample to redundancy" (Lyman and Ames 2007). As a result, larger samples contain more rare taxa and, potentially, a wider range of subsistence activities could be represented. Large differences in excavated volume between different analytic zones of the pilot study could therefore drive taxonomic richness and possible interpretations of changing fishing practices.

\section{Mesh Size}

Another important factor zooarchaeologists have to consider when interpreting animal use at a site is the effect of mesh size on faunal representation. This is a well-documented issue (e.g. Grayson 1984, Cannon 1999) and specifically for fish (Casteel 1972, 1976, Butler 1993, Gordon 1993, Butler and Chatters 1994). For fish remains especially, the addition of a smaller mesh fraction (e.g. 1/8") captures smaller-bodied fish remains that would normally pass through the screen. In an area where a wide variety of taxa may have been exploited, such as the 
Northwest Coast of North America, use of 1/4" mesh may not capture the full spectrum of fish use. Though less matrix overall can be screened using a smaller mesh, questions of fish use and subsistence practices in Northwest coastal sites could potentially be answered most accurately with the addition of a smaller mesh for screening.

\section{Quantification Measures}

Different ways of counting and grouping an assemblage can create markedly different taxonomic lists and change interpretations of economic importance as well. The most basic of a variety of proposed counting and grouping methods is number of identified specimens (NISP) (Grayson 1984), which is a count of all complete and fragmentary identifiable specimens (Lyman 2008). These specimens are then grouped in to taxonomic categories, and NISP is reported for each taxon. This is the simplest measure because it does not require manipulation of the data; there are many proponents of this technique because it is the most direct method and requires the fewest assumptions (e.g. Lyman 2008:140).

Several issues are related to reporting only the raw counts of elements, as outlined in Lyman (2008). One key concern is differential fragmentation rates within and between assemblages that could artificially over or understate the perceived importance of a taxon or assemblage. Additionally, differences between taxa, including bone frequencies and differential bone density can artificially inflate the perceived importance of certain taxa, skewing interpretations. Another concern is 
that there is ambiguity in how to count articulated elements. Consistent rules have not been agreed upon within zooarchaeology, so it is unclear whether to count, for example, a mandible containing teeth as one element, or whether to count each tooth and then the mandible separately.

The most serious issue with using NISP relates to interdependence of the skeletal elements. That is, more than one specimen within a taxon could belong to the same individual animal. This violates the random distribution required for statistical tests, and for some undermines the use of this measure. While recognizing this issue as a serious problem, Lyman (2008) suggests that we could make the assumption that interdependence is randomly distributed across all taxa and strata with the goal of showing that the interdependence issue does not significantly alter the species abundance results.

To address these concerns, especially the issue of interdependence, some researchers propose using a measure called minimum number of individuals (MNI). This measure is defined as the most commonly occurring, non-redundant skeletal element of each taxon in an assemblage (Lyman 2008: 38-39). This measure addresses the interdependence issue of NISP because no animal can have more than one left distal tibia, for example. If there are multiple left distal tibiae in an assemblage, they must have come from multiple individuals.

Minimum animal unit (MAU) is a similar measure to MNI, but side is not taken into account when tallying the most common element per taxa (Reitz and Wing 2008). To calculate MAU, the most frequently occurring element per taxa is 
simply divided by the number of times that occurs in the body. For example, seven Pacific staghorn sculpin dentaries would have to come from at least four fish, since two dentaries occur in each individual. To ensure each element is counted only once, only elements with unique landmarks are used in this calculation. For vertebrae, this means the notochord opening is present and it is more than half complete.

The main issue with MNI (and MAU) is that it is not a fixed value: it can change according to how the assemblages are grouped and sorted. That is, more separations made in the assemblage, between different units for example, will raise the MAU values. Additionally, differential grouping into aggregates could change the rank order of the taxa, which could lead to different interpretations of the relative importance of the taxa. These are serious issues pertaining to repeatability of the identifications and analysis, since there is such a potential for inter-observer variation.

Taxonomic abundance information from NISP and MNI/MAU are highly correlated. Each measure may have serious issues, but according to Grayson (1984), these quantification methods are measuring a consistent property of the assemblage. Lyman (2008) suggests using multiple lines of evidence to interpret assemblages; if NISP and MNI are significantly correlated, the issues pertaining to either method do not have a large impact on interpreting the nature of the assemblage. 


\section{Methods and Materials}

\section{Initial Documentation and Processing}

The fish remains recovered in units 17-20 in block A4, Area A, were borrowed from the Burke Museum of Natural History in Seattle, WA, and were transported to the zooarchaeology lab at Portland State University for analysis. As analysis began, it became apparent that the nested screening technique reported during the excavation was not consistently used in practice. About half of the catalog numbers, each linked to one $10 \mathrm{~L}$ bucket, did not have a 1/8" screen size fraction. Additionally, the fish remains within each bag were not sorted to the screen size recorded on the bag tag. For example, fish remains that were supposed to be from $1 / 4$ " mesh contained much larger specimens that should have been captured in the $1 / 2$ " mesh, as well as much smaller specimens that should have fallen through to $1 / 8^{\prime \prime}$ mesh. In order to ensure comparability with other Northwest Coast assemblages, as well as the other faunal classes within this site (bird, invertebrate, mammal), we rescreened all of the material.

Remains from all separate bags from a given catalog number were screened through nested screens $(1 / 2 ", 1 / 4 ", 1 / 8$ " screen size fractions). We then re-bagged the newly screened material into $>1 / 2 ", 1 / 4 ", 1 / 8$ " and $<1 / 8$ " screen size bags, and assigned new catalog numbers.

I did not include remains which passed through the $1 / 8$ " mesh in my analysis since it is unclear what proportion of original matrix they represent. Also, as noted 
above, about half of catalog numbers were missing $1 / 8^{\prime \prime}$ sample fractions to begin with. When these cataloged remains were rescreened, I only included 1/4'" mesh materials in analysis. These are referred to as "CX" bags. In my analysis, I distinguish results from the " $\mathrm{C}$ " buckets, including size fractions to $1 / 8$ " mesh, from " $\mathrm{CX}$ " bags, which includes $>1 / 4$ " mesh remains.

After the entire assemblage was rescreened, I performed the analysis with the help of Anthony Hofkamp. All specimen identifications were checked by me and ultimately by V. L. Butler before recording. This analysis included remains from 50 buckets. Since each bucket contained $10 \mathrm{~L}$ of matrix, my study focused on remains from $500 \mathrm{~L}$ of matrix.

Analysis of Assemblage

In setting up the fish bone analysis, I first created a list of possible taxa. I used previous faunal analyses in the Salish Sea, Puget Sound, and outer coast of Vancouver Island (Friedman and Croes 1980, Butler 1987, Huelsbeck 1994,McKechnie 2005) and consulted Pacific fisheries guides and reports (Hart 1973, Eschmeyer et al. 1983) to understand life history of these fishes and narrow down possible species within each family based on modern distribution. Finally, I used Miller et al. (1980) MESA (Marine Ecosystems Analysis) report, which presented results from three years of fish surveys along the Strait of Juan de Fuca for the Environmental Protection Agency (EPA) and the National Oceanic and Atmospheric Administration (NOAA). Species were recorded from trolling and 
seining at multiple sites along the Olympic Peninsula; this local information helped resolve the seasonal movements of some fish taxa (salmon, herring), as well as the ubiquity of species in the Strait in modern times. Appendix A presents a list of possible taxa compiled from these sources. All common marine families, including the most common species of large families of flatfish (Pleuronectiformes) and scorpionfishes (Scorpaeniformes), were compiled for the comparative collection. In order to fill gaps in the collection housed in Butler's zooarchaeology lab at Portland State University, additional skeletons were borrowed from R. Kopperl and R. Smith. Appendix B lists the specimens included in the comparative collection for this project.

Specimens were identified to the finest taxonomic level possible based on unique morphology and landmarks, using the comparative collections. For each specimen, I recorded a standard set of information, including provenience (area, unit, stratum, level), mesh size, taxon and element identification (Table 3.1), evidence of burning, cultural modification, such as butchering marks, and the presence/absence of unique landmarks (e.g. Reitz and Wing 2008). Unique landmarks were defined by identifying a non-repetitive portion of the element (e.g. articular surface). If that portion was present, we assigned it as having a landmark. For vertebrae, the presence of the notochord opening in the centrum qualified as having a landmark (Butler 1993, 1996). We distinguished between abdominal and caudal vertebrae based on the presence and orientation of the neural and haemal processes (Wheeler and Jones 1989). Additionally, the last $\sim 5$ vertebrae were too 
similar to distinguish between several families: a "non-salmonid" category was created to track these "too caudal to identify" vertebrae. Salmon vertebrae are easily identifiable, even when highly fragmented, and so this "non-salmonid" category was also used to track the amount of the assemblage that we could not identify to evaluate the potential bias in salmon identification. I also kept track of unidentified fish remains ("Unid" fish) in order to track potential differences in identifiably and fragmentation through time. Identification information was recorded in the Statistical Package for Social Science (SPSS), Version 21 for analysis. 
Table 3.1: Table of identifiable elements by taxon

\begin{tabular}{|c|c|c|c|c|c|c|c|c|c|c|c|c|c|c|c|c|c|c|c|c|c|c|c|c|c|c|c|c|c|}
\hline 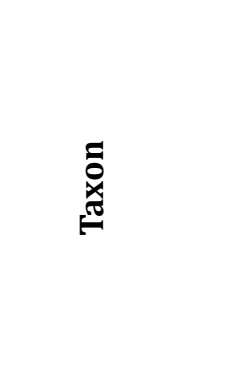 & 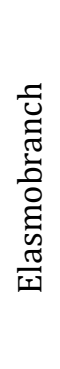 & 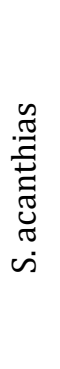 & 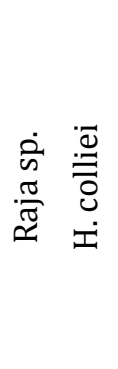 & 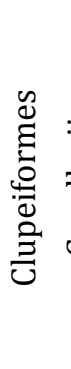 & $\begin{array}{l}:= \\
\tilde{\Xi} \\
\stackrel{\widetilde{\Xi}}{\Xi} \\
ن \\
ن\end{array}$ & 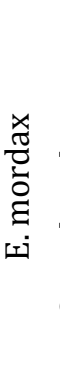 & 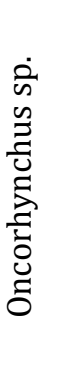 & : & 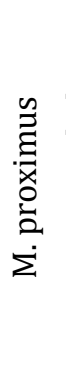 & 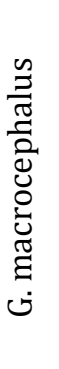 & 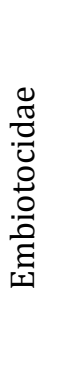 & 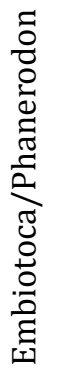 & ت্তু & 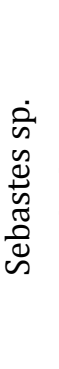 & 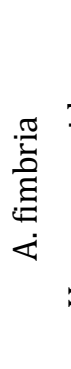 & 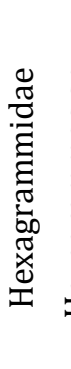 & 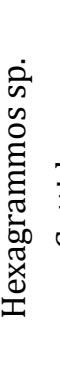 & ن & 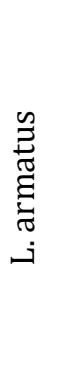 & 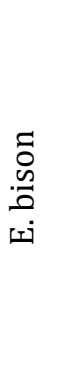 & 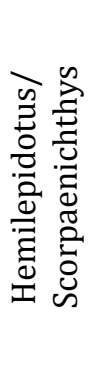 & 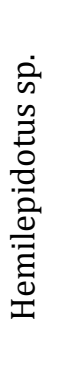 & 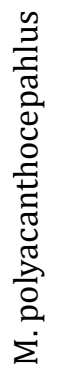 & 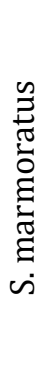 & 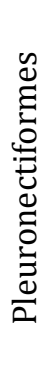 & 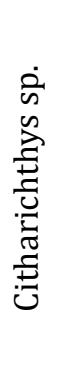 & 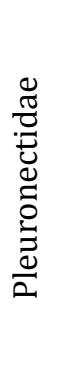 & 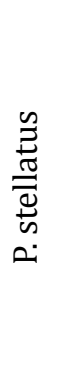 & 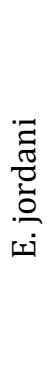 \\
\hline \multicolumn{30}{|l|}{ Element } \\
\hline $\begin{array}{l}\text { angular/ } \\
\text { articular }\end{array}$ & & & & & $\mathrm{x}$ & & $\mathrm{x}$ & & & $\mathrm{x}$ & & & & & & & & $\mathrm{x}$ & $\mathrm{x}$ & $\mathrm{X}$ & & & & & $\mathrm{X}$ & & $\mathrm{x}$ & & $\mathrm{x}$ \\
\hline basioccipital & & & & & $\mathrm{x}$ & & $\mathrm{x}$ & $\mathrm{x}$ & & & $\mathrm{x}$ & & & & & & & $\mathrm{x}$ & $\mathrm{x}$ & $\mathrm{x}$ & & $\mathrm{x}$ & $\mathrm{x}$ & $\mathrm{x}$ & $\mathrm{x}$ & $\mathrm{x}$ & $\mathrm{x}$ & & \\
\hline ceratohyal & & & & & $\mathrm{x}$ & & & & & & & & & & & & & & $\mathrm{x}$ & & & $\mathrm{x}$ & & & $\mathrm{x}$ & & & & \\
\hline dentary & & & & & $\mathrm{X}$ & & & $\mathrm{x}$ & & $\mathrm{X}$ & & & & & & & $\mathrm{x}$ & $\mathrm{X}$ & $\mathrm{x}$ & & & $\mathrm{X}$ & $\mathrm{x}$ & & $\mathrm{X}$ & & $\mathrm{x}$ & $\mathrm{x}$ & \\
\hline ectopterygoid & & & & & & & & & & & & & & & & & & & & & & & $\mathrm{x}$ & & & & & & \\
\hline epihyal & & & & & $\mathrm{x}$ & & & & & $\mathrm{x}$ & & & & & & & & $\mathrm{x}$ & & & & $\mathrm{x}$ & & & & & & & \\
\hline exoccipital & & & & & & & $\mathrm{x}$ & & & & & & & & & & & $\mathrm{x}$ & & & & & & & & & & & \\
\hline frontal & & & & & $\mathrm{x}$ & & & & & & & & & & & & & & & & & $\mathrm{x}$ & & & & & & & \\
\hline hyomandibula & & & & & $\mathrm{X}$ & & & & & $\mathrm{x}$ & & & & & & & $\mathrm{x}$ & $\mathrm{X}$ & $\mathrm{x}$ & $\mathrm{X}$ & & $\mathrm{x}$ & $\mathrm{x}$ & & $\mathrm{x}$ & $\mathrm{x}$ & $\mathrm{x}$ & & \\
\hline maxilla & & & & & $\mathrm{x}$ & & & $\mathrm{x}$ & & $\mathrm{x}$ & & & & $\mathrm{x}$ & & & & $\mathrm{x}$ & $\mathrm{x}$ & $\mathrm{x}$ & & $\mathrm{x}$ & $\mathrm{x}$ & & $\mathrm{x}$ & $\mathrm{x}$ & & & $\mathrm{x}$ \\
\hline opercle & & & & & $\mathrm{x}$ & & & & & & & & & & & & & & $\mathrm{x}$ & $\mathrm{x}$ & & $\mathrm{x}$ & $\mathrm{x}$ & & & & & & \\
\hline
\end{tabular}


otolith

palatine

parasphenoid

premaxilla

preopercle

quadrate

subopercle

supraoccipital

urohyal

vomer

cleithrum

coracoid

mesocoracoid

posttemporal

scapula

supracleithru $\mathrm{m}$

basipterygium vertebra type

$$
\text { II }
$$

vertebra type

$$
\text { III }
$$

indeterminate

vertebra

vertebra

fragment

$\begin{array}{lll}X & x & \\ & & \\ x & x & x\end{array}$

s. $\mathrm{x} \quad \mathrm{x}$

$\mathrm{x}$

X

X $\quad \mathrm{X}$
$\mathrm{X}$

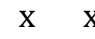

X $\quad \mathrm{X}$

$\begin{array}{lll}\mathrm{X} & \mathrm{X} & \mathrm{X}\end{array}$

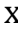

x

$\begin{array}{lll}\mathrm{X} & \mathrm{X} & \mathrm{X}\end{array}$

X $\mathrm{X}$

$\mathrm{X}$ 


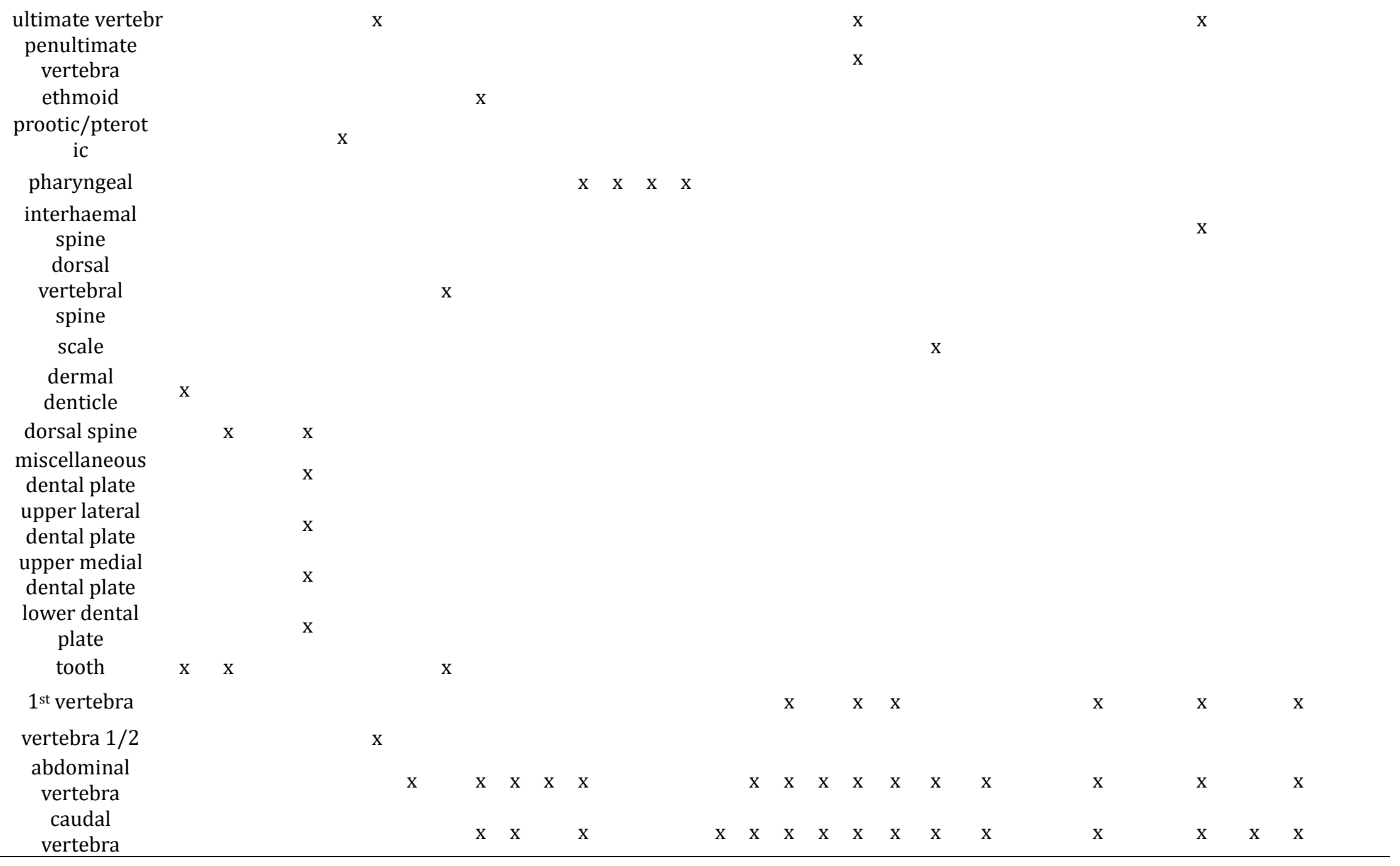

t 
To facilitate comparison with other fish assemblages, I tallied specimens using both NISP and MAU, as discussed above. I then performed several analyses to understand the post-depositional history of the assemblage, in order to ensure that any patterns that emerged were not simply due to taphonomy or recovery techniques. To begin, I compared the two different quantification methods used (NISP and MAU) to see if they were measuring similar properties of the assemblage. I then assessed the effects of different mesh sizes on taxonomic representation, and the effects of excavated volume on the sample size for each AZ in order to ensure sample size was not driving taxonomic patterning.

I compared the "C" fish assemblage across AZs to determine the degree of similarity in fish use over time. I also compared the interior and exterior assemblages in the upper component to determine if differences in taxonomic representation existed within the same time period. Finally, I compared the "CX" assemblage across AZs to track any changes in large-bodied fish use through time that may have been difficult to interpret in the "C" assemblage. To test for change over time in the fish assemblage, I grouped the fish taxa into different habitat types to simplify tracking the large number of different taxa. I then used a chi square test on the " $\mathrm{C}$ " and "CX" assemblages to determine if the fish represented by the defined habitats were distributed across time. This test shows whether or not different patterns of fish use exist before and after the occupation gap that could indicate a CSZ coseismic event. 


\section{Results}

A total of 10,358 fish specimens were documented from the $2 \times 2 \mathrm{~m}$ unit; a

total of 4,345 specimens ( $42 \%)$ were identified to taxon and element. The " $\mathrm{C}$ "

sample NISP was 3,386 specimens, and the "CX" sample NISP was 749. Many

specimens were identifiable to the genus or species level (Table 4.1).

\section{Table 4.1: Identified taxa in area A4, Units 17-20 "C" and "CX" bags}

\begin{tabular}{lll}
\hline Finest Taxonomic Identification & Common Name & NISP \\
\hline Elasmobranchii & Sharks and rays & 24 \\
Squalus acanthias & Spiny dogfish & 153 \\
Raja sp. & Skate & 13 \\
Hydrolagus colliei & Ratfish & 30 \\
Clupeiformes & & 446 \\
Clupea pallasii & Pacific herring & 1220 \\
Engraulis mordax & Anchovy & 1 \\
Oncorhynchus sp. & Salmon & 224 \\
Gadidae & Codfish & 144 \\
Microgadus proximus & Pacific tomcod & 113 \\
Gadus macrocephalus & Pacific cod & 39 \\
Embiotocidae & Surfperch & 15 \\
Embiotoca/Phanerodon & & 1 \\
Damalichthys vacca & Pile perch & 2 \\
Embiotoca lateralis & Striped seaperch & 1 \\
Sebastes sp. & Rockfish & 5 \\
Anoplopoma fimbria & Sablefish & 127 \\
Hexagrammidae & Greenlings and lingcod & 14 \\
Hexagrammos sp. & Greenling & 16 \\
Cottidae & Sculpin & 179 \\
Leptocottus armatus & Pacific staghorn sculpin & 255 \\
Enophrys bison & Buffalo sculpin & 103 \\
Hemilepidotus sp. & Irish lord & 26 \\
Myoxocephalus polyacanthocephalus & Great sculpin & 33 \\
Scorpaenichthys marmoratus & Cabezon & 1 \\
Hemilepidotus/Scorpaenichthys & & 39 \\
Pleuronectiformes & Flatfish & 420 \\
Pleuronectidae & Right and Lefteye Flounders & 15 \\
Platichthys stellatus & Starry flounder & 1 \\
Eopsetta jordani & Petrale sole & 4 \\
Citharichthys sp. & Sanddab & 19 \\
Nonsalmon & & 662 \\
Unidentified Fish & & 6013 \\
\hline & & \\
& &
\end{tabular}


Descriptive Summary of Fish Remains

The following section describes criteria used for specimen identification. When necessary, I have included features used to distinguish closely related species. Information on range, habitat, and modern distribution is included as well.

Class Chondrichthys - cartilaginous fishes

Subclass Elasmobranchii - sharks and rays

Material: 1 indeterminate vertebra, 8 vertebral fragments, 11 dermal denticles, 4 teeth: 24 specimens.

Order Squaliformes

Family Squalidae - dogfish sharks

Squalus acanthias - spiny dogfish

Material: 35 indeterminate vertebrae, 121 vertebral fragments, 6 dorsal spines, 1 tooth: 163 specimens.

Order Rajiformes - skates and rays

Family Rajidae - skates

Raja sp. 
Material: 13 vertebral fragments: 13 specimens.

Remarks: A variety of sharks and rays live in the Northeast Pacific (Hart 1973). Elements were assigned to the Elasmobranchii category if they were too eroded to be separated into one family, but still retained the distinctive morphology common to this class. The teeth, as well as the toothlike scales (Hart 1973), or dermal denticles, embedded in the skin of sharks and rays vary greatly in size and shape, making them difficult to separate below the level of subclass. Additionally, the spool shaped vertebrae, if too eroded to identify the distinctive projecting struts on the Raja vertebrae, cannot be further separated.

Spiny dogfish is the most common species of small shark in the Northeast Pacific (Eschmeyer et al. 1983), and the only member of the Squalidae family living in the study area. They are diverse predators, feeding on many other species found in this assemblage, and congregate where feeding opportunity is abundant. Hart (1973) notes these fish are found at depths of up to 400 fathoms (750 m) to the surface, but are highly migratory and commonly associated with the marine benthos. The elongate, spool shape of the vertebra, even when broken in the middle, allowed for positive species level identification. The dorsal spines, located anterior to the dorsal fin on this species, are distinguishable from those of Hydrolagus colliei based on the presence of a deep posterior groove, a dark, shiny surface, no serration 
on the posterior edge, and convex curvature when viewed laterally. Two of these spines are present on each fish.

Multiple species of the genus Raja (skates) inhabit the study area. Our comparative collection only contains one species, however (Raja rhina), so these vertebrae were identified to the genus level. Skate vertebrae are distinct from those of Squalus acanthias due to their rostro-caudal compression and strong struts that connect to each margin of the vertebra, forming a star shape when broken in half. The genus Raja is the only one within the Rajiformes that is common in shallow water and likely utilized by native fishers. The big skate (Raja binoculata) can reach lengths of $240 \mathrm{~cm}$ (Hart 1973). They are bottom fish that can be found in shallow water to around 200 fathoms (366 m) (Hart 1973).

\author{
Subclass Holocephali \\ Order Chimaeriformes \\ Family Chimaeridae - chimaeras \\ Hydrolagus colliei - spotted ratfish
}

Material: 2 dorsal spines, 3 miscellaneous dental plates, 9 upper lateral dental plates, 11 upper medial dental plates, 5 lower dental plates: 30 specimens.

Remarks: Hydrolagus colliei is the only member of the family found in the North Pacific. They are found in abundance between 50 and 150 fathoms (92-275 m) near 
shore, but have been taken in catches from up to 499 fathoms (913 m) (Hart 1973). They are a common visitor to shallow waters (Hart 1973). In the Strait of Juan de Fuca MESA near shore fish report, Miller et al. (1980) report capture of these fish both with tow net and beach seine methods.

An individual ratfish has six distinctive dental plates: two pairs on the upper jaw, and one pair on the lower jaw. These teeth are distinctive due to their flat, platelike structure, and can be identified by individual teeth. The dorsal spine of ratfish is distinguished from Squalus acanthias spines because they are not curved, have a serrated posterior border, and lack a dark, glossy, enamel-like surface. One of these spines is present on each individual.

\author{
Class Osteichthyes - bony fishes \\ Order Clupeiformes
}

Material: 610 prootic/pterotic: 610 specimens.

$$
\begin{aligned}
& \text { Family Clupeidae - herrings } \\
& \text { Clupea pallasii - Pacific herring }
\end{aligned}
$$

Material: 42 angular/articulars, 10 basioccipitals, 73 ceratohyals, 88 dentaries, 32 epihyals, 14 frontals, 2 parietals, 15 hyomandibulae, 38 maxillae, 49 opercles, 25 quadrates, 16 subopercles, 10 supraoccipitals, 1 urohyal, 9 cleithra, 2 posttemporals, 
1,391 indeterminate vertebrae, 55 vertebral fragments, 14 ultimate vertebrae/hypurals, $341^{\text {st }} / 2^{\text {nd }}$ vertebrae: 1,920 specimens.

Remarks: Two families comprise the Clupeiformes order: Clupeidae (herrings) and Engraulidae (anchovies) (Hart 1973). They are both small schooling fish with seasonal spawning abundances in the Northeast Pacific. Two species of herring are present in the study area: Clupea pallasii (Pacific herring) and Sardinops sagax (Pacific sardine).

Prootics and the pterotics are difficult to distinguish to element. Both consist of a thin, bony plate surrounding a hollow, ball-like structure. As well, these elements are indistinguishable between Pacific herring and northern anchovy. Pacific herring alone was identified in the pilot study analysis, so it is likely that all of the -otics belong to Pacific herring.

A large number of elements were identifiable to the species level due to the completeness of the archaeological elements and the morphologically distinctive characteristics of the cranial elements of Pacific herring compared to other Clupeiformes.

\author{
Order Salmoniformes \\ Family Salmonidae - salmon and trout \\ Oncorhynchus sp.
}


Material: 1 angular/articular, 1 basioccipital, 1 exoccipital, 1 mesocoracoid, 1 pectoral fin ray, 3 basipterygia, 35 Type 2 vertebrae, 55 Type 3 vertebrae, 7 indeterminate vertebrae, 159 vertebral fragments, 6 dorsal vertebral spines, 2 teeth: 272 specimens.

Remarks: Seven species of anadromous salmon (genus Oncorhynchus) inhabit the fresh and saltwater habitats of the study area, including O. gorbuscha (pink salmon), O. keta (chum salmon), O. kisutch (coho salmon), O. nerka (sockeye salmon), O. clarkii (cutthroat trout), O. mykiss (steelhead) and O. tshawytscha (chinook salmon) (Hart 1973). Though attempts have been made to separate these species using osteological material, (e.g. Huber et al. 2011), no reliable morphological criteria have been developed to allow for species level identification of cranial elements, postcranial elements, or vertebrae. Therefore, all elements were identified to the genus level. Several elements, including dorsal vertebral spines and the mesocoracoid, were identified for salmonids alone because of the overall paucity of salmon remains, likely due to lower bone density (Butler 1990).

\section{Order Gadiformes}

Family Gadidae - codfishes 
Material: 2 basioccipitals, 2 dentaries, 3 maxillae, 1 premaxilla, 3 quadrates, 1 vomer, 1 posttemporal, 2 supracleithra, 3 indeterminate vertebrae, 10 vertebral fragments, 1 ethmoid, 50 abdominal vertebrae, 66 caudal vertebrae: 145 specimens.

\section{Microgadus proximus - Pacific tomcod}

Material: 1 premaxilla, 1 posttemporal, 2 vertebral fragments, 4 atlas vertebrae, 91 abdominal vertebrae, 18 caudal vertebrae: 96 specimens.

$$
\text { Gadus macrocephalus - Pacific cod }
$$

Material: 1 angular/articular, 2 dentaries, 2 epihyals, 1 hyomandibula, 4 maxillae, 3 otoliths, 9 premaxillae, 3 quadrates, 6 vomers, 4 posttemporals, 4 supracleithra, 1 abdominal vertebra: 40 specimens.

Remarks: Three species of gadid are common in the Northeast Pacific: Pacific cod (Gadus macrocephalus) walleye pollock (Theragra chalcogramma) and tomcod (Microgradus proximus) (Hart 1973). Pacific cod can reach lengths of about 1 meter (Hart 1973). They come together in deeper water to spawn in winter, and move back to shallow water in the spring. They are mostly benthic, to depths of 300 fathoms (550 m), but can also be taken in very shallow water. Tomcod, a much smaller fish than Pacific cod, are found at depths between 15 and 50 fathoms (27-92 m). Walleye 
pollock can reach lengths to $91 \mathrm{~cm}$, according to Hart (1973), but are often much smaller than this. They are distributed from surface to below 200 fathoms (366 m) (Hart 1973).

Many cranial elements retained morphological characteristics that enabled identification to the species level, especially for Pacific cod. These characteristics include the shape and tooth placement on the dentary and vomer, the morphology of the maxillary condyle, the morphology of the quadrate articulation, the ascending process of the premaxilla, and the morphology of the supracleithrum. Some tomcod vertebrae were distinctive enough to separate, especially the abdominals, based on the solid character of the centra. Vertebrae were identified as Pacific cod based on its extremely large size.

Order Scorpaeniformes

Material: 4 abdominal vertebrae, 6 caudal vertebrae: 10 specimens.

Remarks: This order contains numerous species of rockfish, greenling, and sculpin that are a variety of sizes and are common in the Northeast Pacific. Their vertebrae are heavily built and share some similar features. The vertebrae identified only to the order level were too eroded or broken to identify them to a lower taxonomic level. 


\section{Family Anoplopomatidae \\ Anoplopoma fimbria - Sablefish}

Material: 1 quadrate, 13 indeterminate vertebrae, 18 vertebra fragments, 27 abdominal vertebrae, 79 caudal vertebrae: 138 specimens.

Remarks: Two species within this family are represented in the Northeastern Pacific: Anoplopoma fimbria and Erlipes zonifer. Our archaeological specimens closely matched Anoplopoma, though we lack reference material for Erlipes zonifer so the identification is somewhat tentative. Juvenile sablefish move into shallow water where they would more likely be taken. Adult sablefish and skilfish are typically found at extremely great depths (200-500 fathoms or 366-915 m) (Hart 1973), much beyond the reach of Native fishing technology.

The walls of vertebra identified as sablefish have a fine, fully fenestrated texture, and are lighter built than other Scorpaeniformes vertebrae.

Family Scorpaenidae - scorpionfishes and rockfishes Sebastes sp.

Material: 4 caudal vertebrae: 4 specimens. 
Remarks: Two genera are included in this family: Sebastes and Sebastolobus. At least 35 Sebastes species inhabit the Northeast Pacific (Hart 1973). Two species of Sebastolobus are also present in the study area, but are morphologically distinct from Sebastes. According to Miller et al. (1980), three species of rockfish were captured in beach seine and tow net catches during three years of surveying the Strait of Juan de Fuca. Scorpaenids can be found in many different habitats, including bays, kelp beds, and along the shore (Eschmeyer et al. 1983) and from the intertidal to depths of up to 2800 meters (Hart 1973).

Family Hexagrammidae - greenlings and lingcods

Material: 1 atlas vertebra, 1 abdominal vertebra, 9 caudal vertebrae: 11 specimens.

Hexagrammos sp. - greenlings

Material: 1 dentary, 2 hyomandibulae, 1 basipterygium, 1 abdominal vertebra, 3 caudal vertebrae: 8 specimens.

Remarks: Hexagrammids are a small family of elongate bottom fish, including the lingcod (Ophiodon elongatus), and four species of greenling (Hexagrammos sp.) in the Northeast Pacific (Hart 1973). Two other genera are in this family, each including one species in the northern Pacific: the painted greenling (Oxylebius 
pictus) and the atka mackerel (Pleurogrammus monopterygius) (Eschmeyer et al. 1983). We identified Hexagrammos remains based on an extremely close match to the comparative specimens. However, since we do not have Oxylebius or Pleurogrammus in the reference collection, this identification is tentative. The beach seine and tow net surveys of the Strait of Juan de Fuca collected specimens of kelp, rock, and whitespotted greenling as well as lingcod, but not painted greenling or atka mackerel (Miller et al. 1980).

Greenlings are common in shallow water along rocky shores, but lingcod are found to 230 fathoms $(421 \mathrm{~m})$. They are most commonly distributed in the upper 50 fathoms (92 m) off the coast in the Northeast Pacific (Hart 1973).

Family Cottidae - sculpins

Material: 3 angular/articulars, 6 basioccipitals, 9 dentaries, 1 epihyal, 1 exoccipital, 3 hyomandibulas, 1 maxilla, 1 palatine, 4 premaxillae, 6 quadrates, 2 vomers, 1 coracoid, 1 indeterminate vertebra, 2 vertebral fragments, 3 ultimate vertebrae/hypurals, 1 penultimate vertebra, 4 atlases, 46 abdominal vertebrae, 110 caudal vertebrae: 205 specimens.

Leptocottus armatus - Pacific staghorn sculpin 
Material: 11 angular/articulars, 7 basioccipitals, 3 ceratohyals, 5 dentaries, 12 hyomandibulae, 3 maxillae, 3 opercles, 10 palatines, 3 premaxillae, 2 preopercles, 20 quadrates, 6 vomers, 9 posttemporals, 3 supracleithra, 2 indeterminate vertebrae, 4 atlas vertebrae, 37 abdominal vertebrae, 127 caudal vertebrae: 267 specimens.

$$
\text { Enophrys bison - buffalo sculpin }
$$

Material: 1 angular/articular, 3 basioccipitals, 1 hyomandibula, 1 maxilla, 8 opercles, 2 premaxillae, 6 preopercles, 1 quadrate, 2 vomers, 6 supracleithra, 4 vertebral fragments, 40 lateral line scales, 3 abdominal vertebrae, 27 caudal vertebrae: 105 specimens.

$$
\text { Myoxocephalus polyacanthocephalus - great sculpin }
$$

Material: 1 basioccipital, 2 dentaries, 3 hyomandibulas, 4 maxillae, 1 opercle, 1 premaxilla, 2 preopercles, 3 quadrates, 2 vomers, 1 posttemporal, 2 supracleithra, 4 atlas vertebrae, 3 abdominal vertebrae, 3 caudal vertebrae: 32 specimens.

Hemilepidotus spp. - Irish lord 
Material: 1 basioccipital, 1 ceratohyal, 3 dentaries, 1 epihyal, 1 frontal, 1 hyomandibula, 5 maxillae, 2 opercles, 1 palatine, 4 premaxillae, 1 quadrate, 2 vomers, 2 supracleithra, 2 basipterygia: 27 specimens.

\section{Scorpaenichthys marmoratus - cabezon}

Material: 1 basioccipital: 1 specimen.

\section{Hemilepidotus spp./Scorpaenichthys sp.}

Material: 1 indeterminate vertebra, 8 abdominal vertebrae, 30 caudal vertebrae: 39 specimens.

Remarks: Cottids are a large family of bottom dwelling fish, ranging in size from approximately five $\mathrm{cm}$ up to $99 \mathrm{~cm}$. They are numerous in the northern Pacific, especially in shallow water (Eschmeyer et al. 1983), and on the rocky bottom in kelp forests (Hart 1973). Of the approximately 40 species of sculpin inhabiting the study area, most are extremely small (less than $10 \mathrm{~cm}$ long) (Hart 1973). The six species reported for Tse-whit-zen are the largest common species in the study area: Pacific staghorn sculpin, buffalo sculpin, red and brown Irish lord, great sculpin, and cabezon. All species level identifications are based on the completeness of the archaeological material and the distinctive characteristics separating elements of 
each species. Specimens that were not matched precisely to one of the available specimens were identified to the family level.

Cottid vertebrae are distinctive from other families due to the consistent "sheath" encasing the centrum. While some were identified to the species level, this sheath allowed separation of all cottid vertebrae. Many of the cranial elements identified to family level were too eroded or broken to match them to a comparative specimen, but with morphological features that still identified the elements to the family level. All toothed elements identified to species level are based on differences in tooth patch thickness, tooth orientation, and tooth frequency.

Most elements from the Pacific staghorn sculpin possess a distinctive morphology that allows easy separation from other large cottid species. For example, the distal preopercle has three or four spines pointing dorsally that resemble an antler (Eschmeyer et al. 1983). Buffalo sculpin preopercles also have several spines, as do other taxa, but the orientation and location of these spines differentiates the preopercles from these two species. Pacific staghorn sculpin vertebrae are unique and identifiable based on several characteristics, including the highly fenestrated centrum on the abdominal vertebrae. Additionally, the caudal vertebrae have several distinctive characteristics, including the orientation of the neural and haemal spines and the fenestration on the lateral sides of the centrum. Pacific staghorn sculpin can grow to $46 \mathrm{~cm}$, and are abundant in tide pools and near shore on sandy bottom to moderate depths (91 m) (Eschmeyer et al. 1983). They were collected in beach seines in all three years of survey in the Strait of Juan de 
Fuca, and were very common in collection sites near Tse-whit-zen (Morse Creek and Dungeness spit) (Miller et al. 1980).

The buffalo sculpin has distinctive bony lateral line scales. These are firmly identified to species level. Several elements possess a highly rugose surface texture, especially the preopercle, the supracleithrum, and the opercle. The vertebrae are distinctive, possessing a solid appearance with little fenestration through much of the column. Most of the vertebrae do not possess a strong bar running rostrocaudally, unlike other sculpin vertebrae. Buffalo sculpin are common in rocky and sandy inshore areas up to $20 \mathrm{~m}$. They are moderately sized, reaching $37 \mathrm{~cm}$ (Eschmeyer et al. 1983), and are common in the Strait of Juan de Fuca and off of British Columbia (Hart 1973, Miller et al. 1980).

Two species in the genus Hemilepidotus inhabit the study area: the red Irish lord (Hemilepidotus hemilepidotus) and the brown Irish lord (H. spinosus). The red Irish lord is common along the inside coast of British Columbia (Hart 1973), and is present in the Strait of Juan de Fuca as well (Miller et al. 1980). It is the largest (to $51 \mathrm{~cm}$ ) and most common species in the genus. They can be found in rocky areas near shore, and from the intertidal to about $30 \mathrm{~m}$. The brown Irish lord is smaller (to $29 \mathrm{~cm}$ ) and less common in the study area (Hart 1973). Miller et al. (1980) did not report any in beach seine or tow net along the Strait of Juan de Fuca in three years of survey. However, the brown Irish lord could have been more abundant pre-European contact. Since a brown Irish lord comparative specimen was not available for this 
analysis, all elements matching the red Irish lord were identified to Hemilepidotus spp., though they are likely elements of the red Irish lord.

The vertebrae of the Irish lord species and the cabezon were indistinguishable from each other but distinctive from other cottid vertebrae, leading to the development of the joint category for these vertebrae.

The two largest cottid species in the study area, the great sculpin and the cabezon, possess distinctive cranial elements. The great sculpin can reach lengths of $76 \mathrm{~cm}$, though Hart (1973) notes larger individuals have been reported. They are found from the Puget Sound, Washington state north to the Bering Sea, and are common near shore. They inhabit areas with sand and mud bottom from the intertidal to $244 \mathrm{~m}$ (Eschmeyer et al. 1983).

The cabezon is extremely common throughout its whole range, from Baja California to near Sitka, Alaska. Adults are at times found in shallow water $(1 \mathrm{~m})$. They can be very large, up to $99 \mathrm{~cm}$ (Eschmeyer et al. 1983), though Hart (1973) reports a maximum length of $76 \mathrm{~cm}$. They are abundant from the intertidal to $76 \mathrm{~m}$, and are often caught by fisherman and scuba divers (Eschmeyer et al. 1983).

\section{Order Perciformes}

Family Embiotocidae - surfperches

Material: 1 basioccipital, 1 basipterygium, 1 lower pharyngeal, 1 atlas vertebra, 12 abdominal vertebrae, 5 caudal vertebrae: 21 specimens. 
Embiotoca/Phanerodon

Material: 1 lower pharyngeal: 1 specimen.

Damalichthys vacca - pile perch

Material: 2 lower pharyngeals: 2 specimens.

Embiotoca lateralis - striped seaperch

Material: 1 lower pharyngeal: 1 specimen.

Remarks: Nine species of surfperch currently live in the shallow waters of the northeastern Pacific, though other species that currently live only off the coast of California could have inhabited more northern waters pre-European contact. Depending on the species, these fish live inshore, and their habitats vary from living in the surf of sandy or rocky beaches, in sheltered bays, or near piers, eelgrass beds, or underwater structures (Eschmeyer et al. 1983). They can be found from the surface to as deep as 70 fathoms $(128 \mathrm{~m})($ Hart 1973). The pile perch is the largest of these (up to $44 \mathrm{~cm}$ ) and common in the study area. The shiner perch (Cymatogaster aggregata) is the smallest (to about $15 \mathrm{~cm}$ ) (Hart 1973). Eschmeyer 
et al. (1983) note that these are abundant throughout their entire range, and can be easily caught from piers.

The surfperch lower pharyngeal is the only element identifiable to the species level based on tooth pattern and element morphology. The Embiotoca/Phanaedron grouping was created because due to breakage, the pharyngeal was too fragmentary to separate further.

$$
\text { Order Pleuronectiformes - left and righteye flounders }
$$

Material: 3 angular/articulars, 6 basioccipitals, 1 ceratohyal, 4 dentaries, 4 hymandibulas, 6 maxillae, 4 premaxillae, 6 quadrates, 4 urohyals, 6 vomers, 4 cleithra, 2 posttemporals, 1 scapula, 2 supracleithra, 5 indeterminate vertebrae, 2 vertebral fragments, 2 ultimate vertebrae/hypurals, 4 interhaemal spines, 10 atlas vertebrae, 45 abdominal vertebrae, 315 caudal vertebrae: 436 specimens.

$$
\text { Family Bothidae - lefteye flounders }
$$

Citharichthys sp.

Material: 1 basioccipital, 5 hyomandibulae, 2 maxillae, 12 caudal vertebrae: 20 specimens.

Family Pleuronectidae - righteye flounders 
Material: 2 angular/articulars, 1 basioccipital, 1 dentary, 4 hyomandibulas, 1 palatine, 1 vomer, 1 cleithrum, 1 atlas vertebra, 2 abdominal vertebrae, 1 caudal vertebra: 15 specimens.

\section{Platichthys stellatus - starry flounder}

Material: 1 dentary, 1 stellate scale: 2 specimens

$$
\text { Eopsetta jordani - petrale sole }
$$

Material: 1 angular/articular, 2 maxillae, 1 premaxilla: 4 specimens.

Remarks: Right (Pleuronectidae) and lefteye (Bothidae) flounders are distinctive in that they have an asymmetrical cranium, with both eyes located on one side. The eyed-side is also pigmented, whereas the "blind" side is lighter or white because it is usually in contact with the bottom. All flatfish are bottom fish, and many bury themselves in sediment, leaving just their eyes showing (Eschmeyer et al. 1983, Hart 1973).

Skeletally, flatfish have characteristic elements due to the asymmetry of their crania, but many elements are difficult to distinguish within species or family and are therefore identified to the order level. Many, but not all, Pleuronectiformes 
vertebrae have a distinctive "star shape," made by two transverse processes radiating dorso-ventrally on either side of the vertebral centrum (Sakamoto 1984). These are especially visible on most caudal vertebrae. Additionally, the notochord opening on Pleuronectiformes vertebrae is situated closer to the neural arch, and the vertebrae are generally oblong dorso-ventrally. A "lined" texture is characteristic of the lateral bar on the centrum. The abdominal vertebral face displays a distinctive asymmetry to the notochord opening, and the neural processes are not offset from the centrum, but directly adjacent. In some families, the atlas vertebra does not have an articulated neural spine.

Nineteen pleuronectid species inhabit the study area; due to similarity within this family, few elements were identifiable below the family level. Bothids include two species in the study area: Citharichthys sordidus (Pacific sanddab) and $C$. stigmaeus (speckled sanddab); both are always left-eyed.

Those elements identified as Pleuronectidae were assigned based on minimal similarity with the sanddab comparative specimens. Pleuronectids attain much larger sizes (most around $60 \mathrm{~cm}$, some as large as $267 \mathrm{~cm}$ ) than the bothids, allowing assignment of very large elements to the family level (Eschmeyer et al. 1983). Several pleuronectid species are common in the study area, including the starry flounder (Platichthys stellatus) and several sole species (especially Paroprhys vetulus [English sole] and Psettichthys melanostictus [sand sole]) (Miller et al. 1980). Other species (e.g. Eopsetta jordani, or petrale sole) are plentiful in the northeastern Pacific as well, so the above list is not exhaustive (e.g. Hart 1973). These fish range 
from the surface to very deep water: some can be found past $1000 \mathrm{~m}$, characteristically on the sandy bottom (Eschmeyer et al. 1983). Many of these species are of commercial importance in modern times, and support moderate fisheries (Hart 1973, Eschmeyer et al. 1983).

The starry flounder (Platichthys stellatus) is the only species in the study area that can be right or left-eyed. The distinctive tooth pattern and row of foramina on the dentary allowed for species level identification. Additionally, only the starry flounder has small tubercles or scales, allowing assignment of these scales to the species level. After halibut (Hippoglossus stenolepis), this is one of the largest species in the family, attaining sizes of $91 \mathrm{~cm}$ (Hart 1973).

The petrale sole elements were identified based on a very close match to the distinctive tooth pattern and morphology of the jaw. Two rows of small teeth line the upper jaw, differing the petrale sole from other taxa. This is an important food fish in modern times because it is large, reaching up to $70 \mathrm{~cm}$ (Eschmeyer et al. 1983), and the meat is of excellent quality. They can be found in abundance in the study area, from the surface to 300 fathoms (550 m) (Hart 1973).

All elements identified to Citharichthys sp. were distinct from all pleuronectid taxa in the comparative collection. Sanddab caudal vertebrae are especially distinctive; the haemal arch meets near to the centrum, forming a circular opening adjacent to the centrum. The speckled sanddab (C. stigmaeus) reaches $15 \mathrm{~cm}$ and is abundant on sandy beaches and in shallow water (above $91 \mathrm{~m}$ ) in the study area (Hart 1973, Miller et al. 1980). The Pacific sanddab (C. sordidus) is larger, reaching 
$41 \mathrm{~cm}$, and can be found from surface to 167 fathoms (306 m). It is common in shallow water in the study area (Hart 1973).

Quantification: NISP and MAU

As discussed in Chapter 2, the way specimens are counted and grouped can create markedly different taxonomic lists and significantly affect resulting interpretations. To assess the potential for this difference, I compared the calculated NISP and MAU (Appendix C) values with a Spearman's rank order correlation (Table 4.2). To represent this relationship graphically, I performed a log transformation of these two variables. This makes curvilinear relationships linear (Lyman 2008: 51), showing the degree of correlation between variables more clearly. Results of this test show that the two measures are significantly correlated $\left(r_{s}=.688, p<.01 ;\right.$ Fig 4.1); I will therefore use NISP for the remainder of the analysis. The bolded taxa in Table 4.2 show that for some taxa, the rank orders of MAU and NISP were very different, which explains some of the variability in Figure 4.1. This is especially true for $H$. colliei, or ratfish. The ratfish NISP rank is low, due to the minimal identifiable elements from this taxon (tooth plates and a dorsal spine). However, the MAU rank is high for this taxon because these elements are easily identifiable and there are only two of each type of tooth plate per individual (six total). Though the quantification measures are significantly correlated, the ratfish example shows clearly the potential for a taxon to be over or under represented in perceived importance based on these rankings. 
Table 4.2: NISP, MAU and Spearman's ranks for each taxon. Taxa in bold have substantial differences in ranks

\begin{tabular}{lllll}
\hline Taxon & NISP & Rank & MAU & Rank \\
\hline Squalus acanthias & 154 & 5 & 3 & 11 \\
Hydrolagus colliei & 30 & 13 & 6 & 3.5 \\
Clupea pallasii & 1220 & 1 & 112 & 1 \\
Engraulus mordax & 1 & 25 & 1 & 22.5 \\
Onchorhynchus sp. & 225 & 3 & 3 & 11 \\
Gadidae & 145 & 6 & 3 & 11 \\
Microgadus proximus & 114 & 8 & 4 & 7 \\
Gadus macrocephalus & 40 & 10 & 6 & 3.5 \\
Hexagrammidae & 14 & 19 & 1 & 22.5 \\
Cottidae & 179 & 4 & 5 & 5 \\
Sebastes sp. & 5 & 20 & 1 & 22.5 \\
Anoplopoma fimbria & 127 & 7 & 3 & 11 \\
Hexagrammos sp. & 16 & 18 & 1 & 22.5 \\
Leptocottus armatus & 255 & 2 & 10 & 2 \\
Enophrys bison & 103 & 9 & 4 & 7 \\
Hemilepidotus sp. & 27 & 14 & 3 & 11 \\
Myoxocephalus polyacanthocephalus & 33 & 12 & 4 & 7 \\
Scorpaenichthys marmoratus & 1 & 25 & 1 & 22 \\
Hemilepidotus/Scorpaenichthys & 39 & 11 & 2 & 15.5 \\
Embiotocidae & 15 & 16.5 & 1 & 22.5 \\
Embiotoca/Phanerodon & 1 & 25 & 1 & 22.5 \\
Damalichthys vacca & 2 & 22 & 2 & 15.5 \\
Embiotoca lateralis & 1 & 25 & 1 & 22.5 \\
Pleuronectidae & 15 & 16.5 & 2 & 15.5 \\
Citharichthys sp. & 19 & 15 & 2 & 15.5 \\
Platichthys stellatus & 1 & 25 & 1 & 22.5 \\
Eopsetta jordani & 4 & 21 & 1 & 22.5 \\
\hline
\end{tabular}




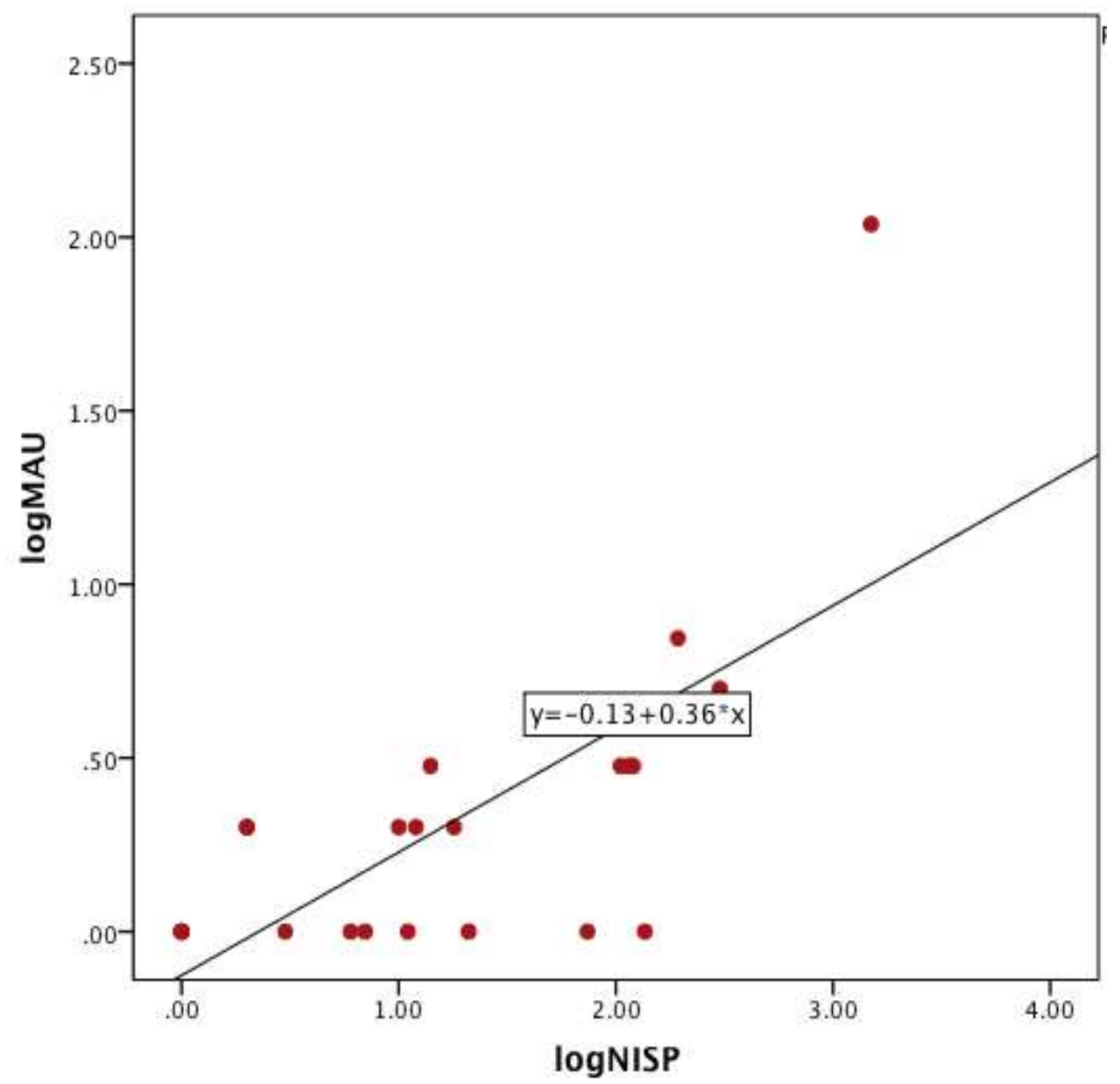

Figure 4.1: Scatter plot showing significant correlation between logNISP and $\log M A U$ values.

Sample Size

Patterns in taxonomic representation can be affected by sample size. As the volume of excavated matrix increases, assemblages tend to increase in size and diversity, resulting in a greater NISP value as well as higher taxonomic richness (e.g. Lyman and Ames 2007). These differences can be based on differences in animal use, but they also could simply be due to different recovery methods such as 
variation in excavated volume. Table 4.3 outlines the excavated volume and sample size ("C" bag sample) for each AZ.

Table 4.3: Excavated volume and sample size for " $\mathrm{C}$ " bags

\begin{tabular}{llll}
\hline Analytic Zone & Matrix Analyzed & NISP & N Taxa \\
\hline AZ 04.01 & $40 \mathrm{~L}$ & 415 & 20 \\
AZ 04.03 & $90 \mathrm{~L}$ & 1485 & 23 \\
AZ 04.05 & $150 \mathrm{~L}$ & 1242 & 27 \\
AZ 04.06 & $60 \mathrm{~L}$ & 177 & 14 \\
AZ 04.07 & $90 \mathrm{~L}$ & 67 & 12
\end{tabular}

*AZ 04.02 and AZ 04.04 were not included because these zones only contained "CX" bag samples

One way to test if patterns are related to actual human behavior as opposed to excavated volume is to see if sample size for each $\mathrm{AZ}$ is correlated to the amount of matrix excavated. If correlated, then changes in taxonomic abundances over time would at least partially be related to the excavation technique and not to the human behavior. A Spearman's rank order correlation test shows NISP and excavated volume for each $\mathrm{AZ}$ are not correlated $\left(\mathrm{r}_{\mathrm{s}}=.325, \mathrm{p}>.1\right.$; Fig 4.2). Therefore, the sample sizes are not a function of the different amount of matrix excavated from each AZ. 


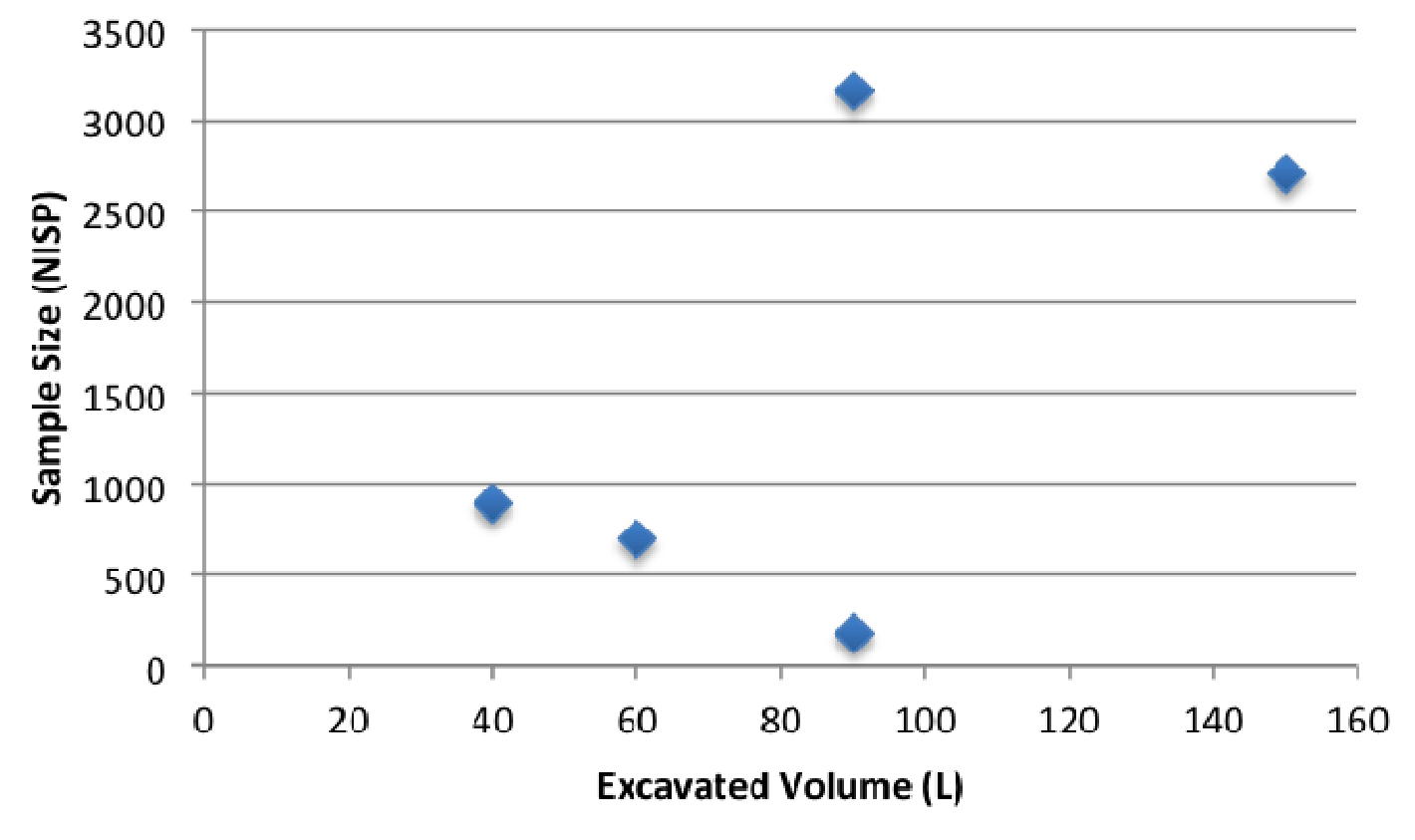

Figure 4.2: “C”' bags, the relationship between sample size and excavated volume for each analytic zone

Mesh Size

Differential use of mesh size can also affect taxonomic representation, especially for fish bone (Casteel 1972, 1976). Tse-whit-zen faunal results illustrate this well (Fig 4.3). When $>1 / 4$ mesh is considered, larger bodied fishes such as some sculpins, salmonids, spiny dogfish (shark dominating the elasmobranch category), and Pacific cod (Gadidae) dominate the assemblage. When the $>1 / 8$ " sample is added in, several previously unrepresented taxa become much more prominent, including sablefish, Pacific tomcod and most importantly Pacific herring, which comprises over $50 \%$ of the "C" assemblage. Given this, when discussing patterning in the fish record, I will distinguish result from the "C" buckets, that includes the 1/4" and the $1 / 8$ " mesh, from "CX" buckets, which includes $>1 / 4$ " mesh only. 


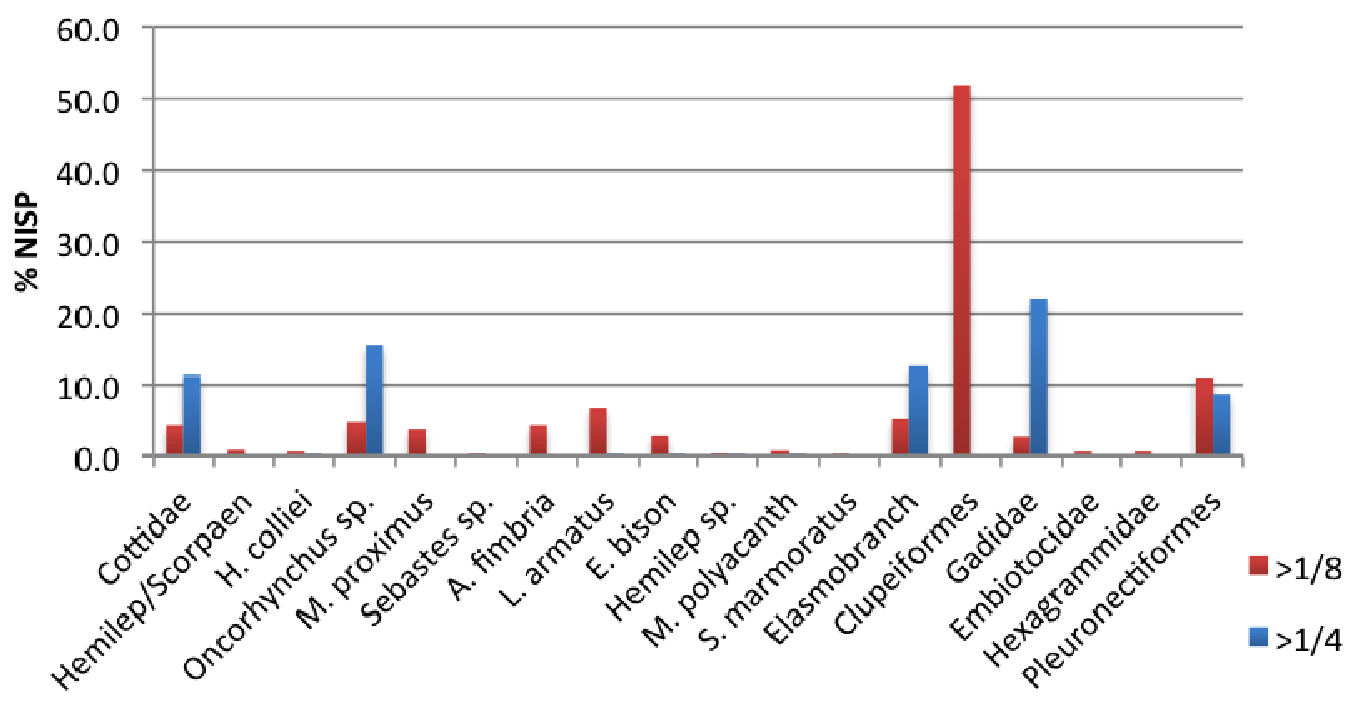

Figure 4.3: Clustered bar chart comparing taxonomic representation of $>1 / 4$ " mesh recovery with $>1 / 8$ " mesh recovery

These issues are important to consider before attempting to explain changes in faunal abundance to actual changes in human or animal behavior. I am now able to look for changes over time in the fish record and attribute them more confidently to human or animal behavior as opposed to taphonomic, recovery or analytic issues.

The Tse-whit-zen Fish Assemblage

The results of this analysis across AZs show a wide variety of fish use through time, which is consistent with information from other area sites (Friedman and Croes 1980, Butler 1987, Huelsbeck 1994, McKechnie 2005). In the “C” bag sample, Pacific herring, small cottids (Pacific staghorn sculpin, buffalo sculpin), and flatfish species are common. Species including Pacific cod, salmon, sablefish and spiny dogfish are also used commonly in the site. Perhaps surprisingly, rockfish and 
surfperch are extremely uncommon in this assemblage, and lingcod and plainfin midshipman are completely absent from this assemblage. These results are inconsistent with other area site reports, which report larger numbers of these taxa. The "CX" sample shows a different species composition. Due to the lack of the $>1 / 8$ " fraction, Pacific cod, salmon, and spiny dogfish are still common in this sample.

Tracking changes in taxonomic abundances by AZ is one way to assess changes in fish use over time. Some AZs have very little material in them, so in order to use them for comparison I combined the upper component AZs (A4.01-A4.04) and the lower component AZs (A4.05-A4.07) together. Additionally, if a taxon had a very small sample size ( $<5$ NISP) I omitted it in order to have an appropriate assemblage for statistical tests. In all tables below, the categories "small cottid" and "large cottid" separate the Pacific staghorn sculpin and buffalo sculpin, smaller cottids found in shallow water (to 12-18”), from the larger cottid species, including Irish lord, great sculpin, and cabezon. These three taxa are found in deeper water and attain larger sizes (to 20-30") (Hart 1973).

I will begin with a comparison of the " $\mathrm{C}$ " bag sample, which had large sample sizes for A4.01 and A4.03, but no material in A4.02 or A4.04, and small samples sizes in A4.06 and A4.07. Therefore, I combined the AZs into two aggregates. When these combined lower and upper component assemblages are compared, there is little change in taxonomic representation: no taxon is present in one component and not the other. 
Several interesting shifts in taxonomic abundances are shown between the lower and upper component. The Clupeiformes category dominates both assemblages, with all other taxa making up $\sim 10 \%$ or less of each. In the lower component, taxa are slightly more evenly distributed, but Clupeiformes make up $40 \%$ of the total assemblage. The upper component has a much higher percentage of Clupeiformes (60\%). A $\chi^{2}$ analysis of the distribution of taxa shows a statistically significant difference from the lower to the upper component (Table 4.4), driven mostly by the large residual for the Clupeiformes category $\left(\chi^{2}=126.8, p<.001\right)$. Several other significant residuals (Elasmobranchii, Oncorhynchus sp., A. fimbria, Cottidae) indicate the distribution of these taxa contributes to the significant $\chi^{2}$ value as well. These categories all have significantly higher frequency than expected in the lower component, and a significantly lower frequency in the upper component. This could indicate a shift to a greater focus on herring (Clupeiformes) in the upper component, though all taxa are represented in the upper component as well. 


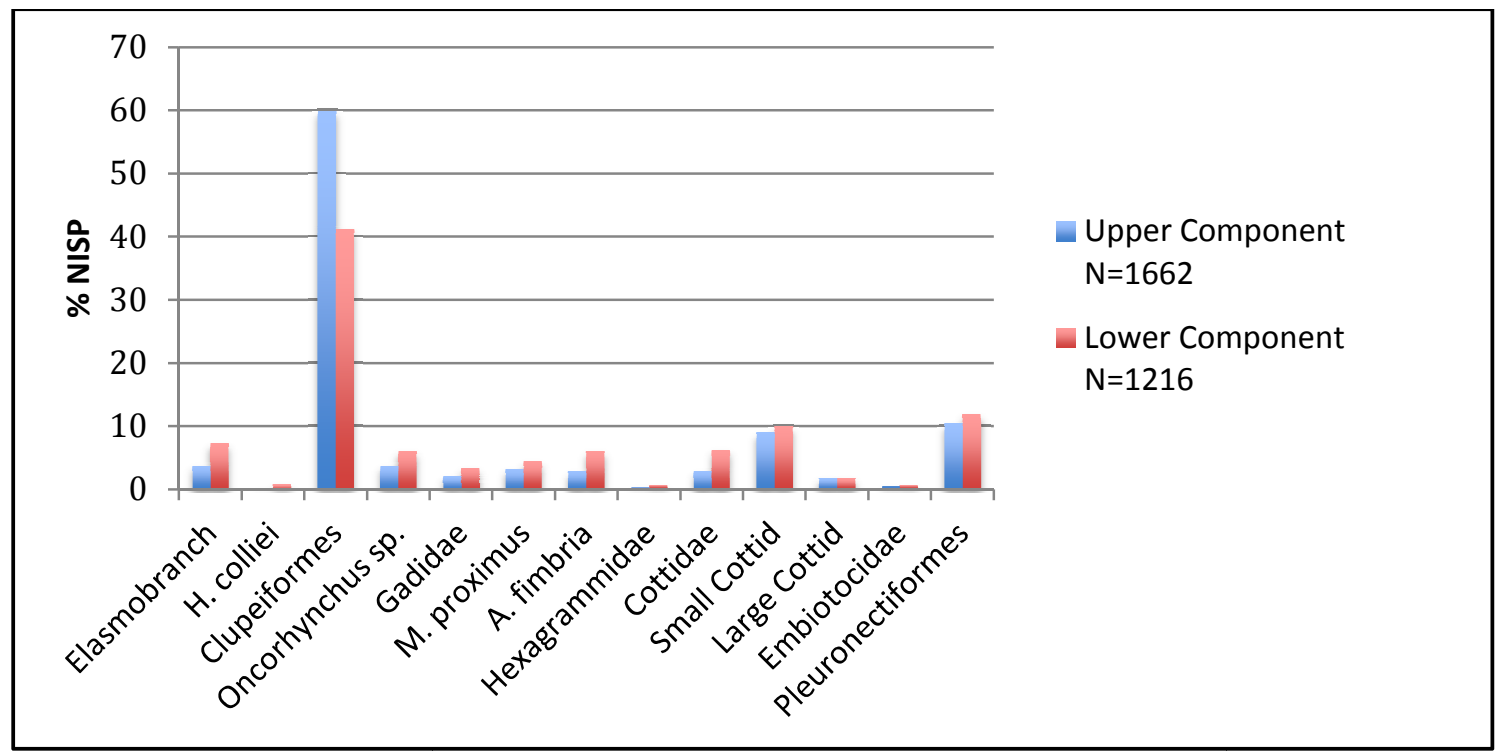

Figure 4.4: Taxonomic representation for lower and upper component: "C" bags 
Table 4.4: Taxonomic representation separated by component: " $\mathrm{C}$ " bags. Values in bold are significant at $p=.05$

\begin{tabular}{|c|c|c|c|c|}
\hline $\begin{array}{l}\text { Finest } \\
\text { Taxa }\end{array}$ & $\begin{array}{l}\text { Common } \\
\text { Name }\end{array}$ & & $\begin{array}{l}\text { Upper } \\
\text { Component }\end{array}$ & $\begin{array}{l}\text { Lower } \\
\text { Component }\end{array}$ \\
\hline \multirow[t]{3}{*}{ Elasmobranchii } & $\begin{array}{l}\text { Sharks and } \\
\text { Rays }\end{array}$ & Count & 61 & 87 \\
\hline & & Expected Count & 85.5 & 62.5 \\
\hline & & Std. Residual & -2.6 & 3.1 \\
\hline \multirow{3}{*}{ H. colliei } & Ratfish & Count & 4 & 10 \\
\hline & & Expected Count & 8.1 & 5.9 \\
\hline & & Std. Residual & -1.4 & 1.7 \\
\hline \multirow{3}{*}{$\begin{array}{l}\text { Clupeiformes } \\
\text { (dominated by } C \text {. } \\
\text { pallasii) }\end{array}$} & $\begin{array}{l}\text { Herring and } \\
\text { Anchovy }\end{array}$ & Count & 995 & 501 \\
\hline & & Expected Count & 863.9 & 632.1 \\
\hline & & Std. Residual & 4.5 & -5.2 \\
\hline \multirow[t]{3}{*}{ Oncorhynchus sp. } & $\begin{array}{l}\text { Pacific } \\
\text { Salmon }\end{array}$ & Count & 62 & 74 \\
\hline & & Expected Count & 78.5 & 57.5 \\
\hline & & Std. Residual & -1.9 & 2.2 \\
\hline \multirow{3}{*}{$\begin{array}{l}\text { Gadidae } \\
\text { (dominated by } G \text {. } \\
\text { macrocephalus) }\end{array}$} & Codfish & Count & 33 & 41 \\
\hline & & Expected Count & 42.7 & 31.3 \\
\hline & & Std. Residual & 1.5 & 1.7 \\
\hline \multirow[t]{3}{*}{ M. proximus } & $\begin{array}{l}\text { Pacific } \\
\text { tomcod }\end{array}$ & Count & 52 & 53 \\
\hline & & Expected Count & 60.6 & 44.4 \\
\hline & & Std. Residual & 1.1 & 1.3 \\
\hline \multirow[t]{3}{*}{ A. fimbria } & Sablefish & Count & 46 & 74 \\
\hline & & Expected Count & 69.3 & 50.7 \\
\hline & & Std. Residual & -2.8 & 3.3 \\
\hline \multirow[t]{3}{*}{ Hexagrammidae } & $\begin{array}{l}\text { Greenling and } \\
\text { lingcod }\end{array}$ & Count & 6 & 7 \\
\hline & & Expected Count & 7.5 & 5.5 \\
\hline & & Std. Residual & -.6 & .6 \\
\hline \multirow[t]{3}{*}{ Cottidae } & Sculpin & Count & 46 & 75 \\
\hline & & Expected Count & 69.9 & 51.1 \\
\hline & & Std. Residual & -2.9 & 3.3 \\
\hline \multirow[t]{3}{*}{ Small Cottid } & & Count & 149 & 121 \\
\hline & & Expected Count & 155.9 & 114.1 \\
\hline & & Std. Residual & -.6 & .6 \\
\hline \multirow[t]{3}{*}{ Large Cottid } & & Count & 29 & 21 \\
\hline & & Expected Count & 28.9 & 21.1 \\
\hline & & Std. Residual & .0 & .0 \\
\hline \multirow[t]{3}{*}{ Embiotocidae } & Surfperch & Count & 6 & 8 \\
\hline & & Expected Count & 8.1 & 5.9 \\
\hline & & Std. Residual & -.7 & .9 \\
\hline \multirow[t]{3}{*}{ Pleuronectiformes } & Flatfish & Count & 173 & 144 \\
\hline & & Expected Count & 183.1 & 133.9 \\
\hline & & Std. Residual & -.7 & .9 \\
\hline
\end{tabular}


The upper component is split into an interior context and an exterior midden context. Here, I compare these two areas to understand the distribution of the fish bones across the upper component. The sample size from the interior area (A4.01) is much smaller than that of the exterior, indicating most fish bone in the upper component is situated outside the structure. This makes sense according to the ethnographic record of house cleaning and trash disposal (Gunther 1927). The exterior context is dominated by Clupeiformes ( $>60 \%$ of the assemblage), again with all other taxa comprising $\sim 10 \%$ or less of the assemblage. A $\chi^{2}$ analysis of the distribution presents a statistically significant result $\left(\chi^{2}=48.25, \mathrm{p}<.001\right.$; Table 4.5). Similar to the previous comparison, Clupeiformes are significantly more common in the exterior context, but again this category still has a strong presence in both contexts. Though a variety of taxa are represented, the very large abundance of Clupeiformes further suggests a focus on these fish in the upper component. 


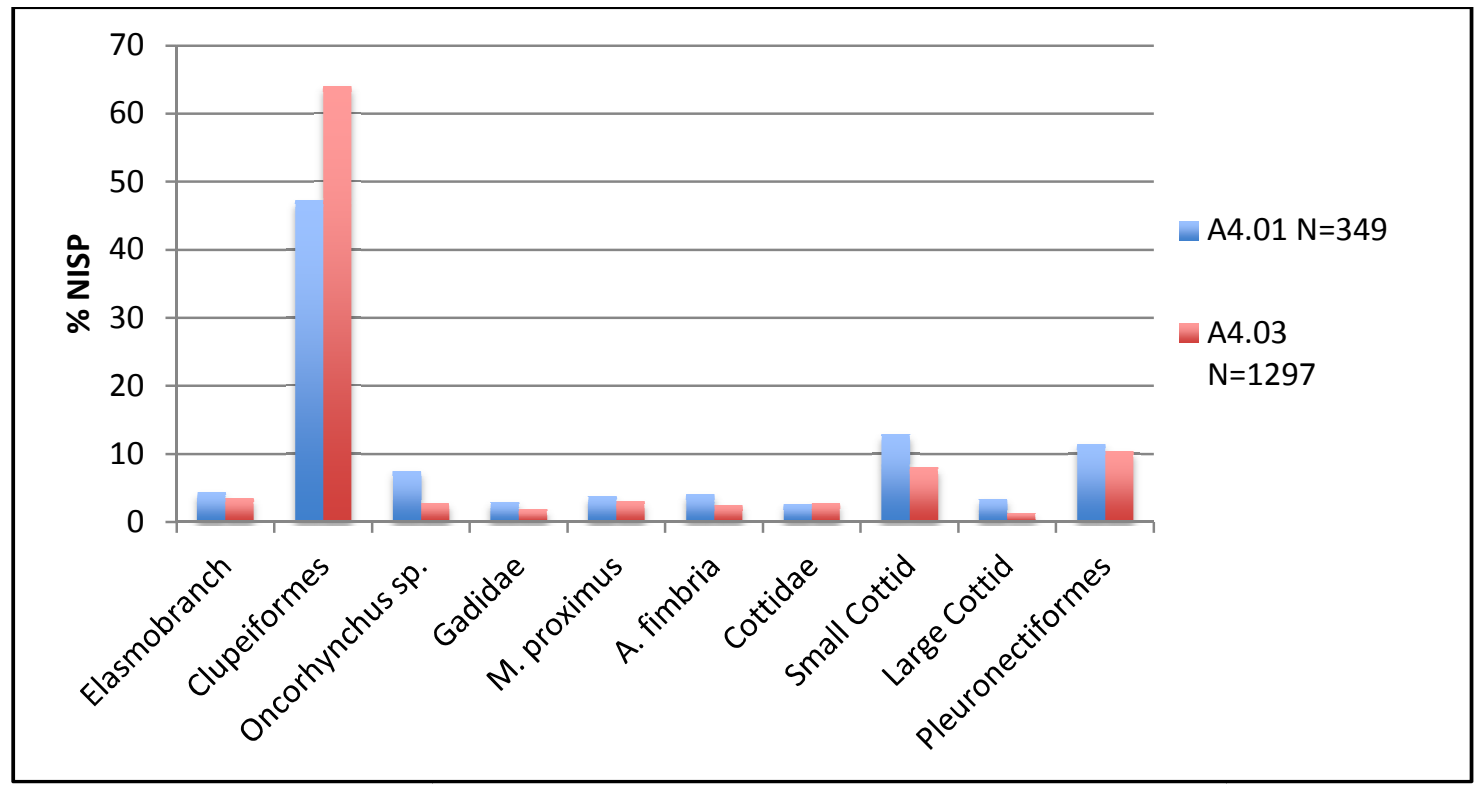

Figure 4.5: Taxonomic representation: comparison of upper component interior and exterior assemblages: "C" bags 
Table 4.5: Taxonomic representation: comparison of the interior and exterior AZs of the upper component: " $C$ " bags. Values in bold are significant at $p=.05$

\begin{tabular}{|c|c|c|c|c|}
\hline $\begin{array}{l}\text { Finest } \\
\text { Taxa }\end{array}$ & $\begin{array}{l}\text { Common } \\
\text { Name }\end{array}$ & & $\begin{array}{l}\text { A4.01: } \\
\text { Interior }\end{array}$ & $\begin{array}{l}\text { A4.03: } \\
\text { Exterior }\end{array}$ \\
\hline \multirow[t]{2}{*}{ Elasmobranchii } & $\begin{array}{l}\text { Sharks and } \\
\text { Rays }\end{array}$ & Count & 15 & 46 \\
\hline & & $\begin{array}{l}\text { Expected Count } \\
\text { Std. Residual }\end{array}$ & $\begin{array}{l}12.9 \\
.6\end{array}$ & $\begin{array}{l}48.1 \\
-.3\end{array}$ \\
\hline \multirow[t]{3}{*}{$\begin{array}{l}\text { Clupeiformes } \\
\text { (dominated by } C \text {. } \\
\text { pallasii) }\end{array}$} & $\begin{array}{l}\text { Herring and } \\
\text { Anchovy }\end{array}$ & Count & 165 & 830 \\
\hline & & Expected Count & 211 & 784 \\
\hline & & Std. Residual & -3.2 & 1.6 \\
\hline \multirow[t]{3}{*}{ Oncorhynchus sp. } & $\begin{array}{l}\text { Pacific } \\
\text { Salmon }\end{array}$ & Count & 26 & 36 \\
\hline & & Expected Count & 13.1 & 48.9 \\
\hline & & Std. Residual & 3.5 & -1.8 \\
\hline \multirow[t]{3}{*}{$\begin{array}{l}\text { Gadidae } \\
\text { (dominated by } G \text {. } \\
\text { macrocephalus) }\end{array}$} & Codfish & Count & 10 & 23 \\
\hline & & Expected Count & 7 & 26 \\
\hline & & Std. Residual & 1.1 & -.6 \\
\hline \multirow[t]{3}{*}{ M. proximus } & $\begin{array}{l}\text { Pacific } \\
\text { tomcod }\end{array}$ & Count & 13 & 39 \\
\hline & & Expected Count & 11 & 41 \\
\hline & & Std. Residual & .6 & -.3 \\
\hline \multirow[t]{3}{*}{ A. fimbria } & Sablefish & Count & 14 & 32 \\
\hline & & Expected Count & 9.8 & 36.2 \\
\hline & & Std. Residual & 1.4 & -.7 \\
\hline \multirow[t]{3}{*}{ Cottidae } & Sculpin & Count & 9 & 37 \\
\hline & & Expected Count & 9.8 & 36.2 \\
\hline & & Std. Residual & .2 & .1 \\
\hline \multirow[t]{3}{*}{ Small Cottid } & & Count & 45 & 104 \\
\hline & & Expected Count & 31.6 & 117.4 \\
\hline & & Std. Residual & 2.4 & -1.2 \\
\hline \multirow[t]{3}{*}{ Large Cottid } & & Count & 12 & 17 \\
\hline & & Expected Count & 6.1 & 22.9 \\
\hline & & Std. Residual & 2.4 & -1.2 \\
\hline \multirow[t]{3}{*}{ Pleuronectiformes } & Flatfish & Count & 40 & 133 \\
\hline & & Expected Count & 36.7 & 136.3 \\
\hline & & Std. Residual & .5 & -.3 \\
\hline
\end{tabular}

A comparison of the "CX" assemblage (broken into an upper and lower component assemblage due to small sample sizes) shows a more even distribution of taxa, though fewer taxa overall had large enough sample sizes to be included in the comparison (Fig 4.6). The Clupeiformes and Pleuronectiformes categories make 
up the largest proportion of both assemblages; Oncorhynchus sp. and Gadidae are also strongly represented in the lower component. The $\chi^{2}$ analysis results are again statistically significant $\left(\chi^{2}=30.9, \mathrm{p}<.001\right.$; Table 4.6) for this comparison. The distribution of the elasmobranch and Oncorhynchus sp. categories had the highest residuals in this example, however; showing that the distribution of the Clupeiformes was closer to expected here.

This comparison is particularly interesting because it highlights patterns that are subtle in the "C" bag comparison (Fig 4.4) relating to larger-bodied fishes. First, Oncorhynchus sp has a significantly higher representation in the lower component than in the upper component; possibly suggesting a greater focus on salmon before the occupation gap. This is a consistent pattern with the Elasmobranchii (sharks and rays, mostly S. acanthias) and Gadidae (mostly the large G. macrocephalus).

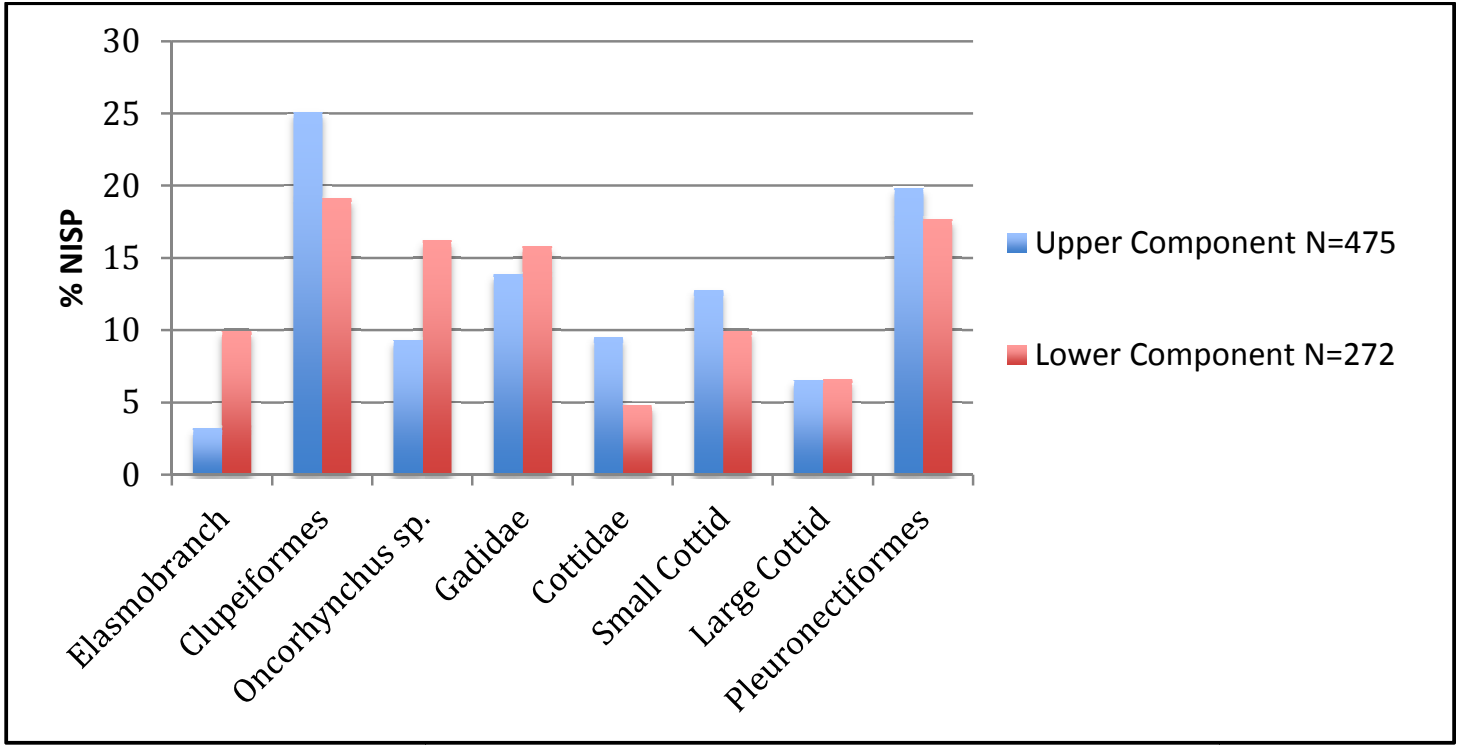

Figure 4.6: Taxonomic representation for lower and upper component: " $C X$ " bags 
Table 4.6: Taxonomic representation: comparison of the lower and upper component: "CX" bags. Values in bold are significant to $p=.05$

\begin{tabular}{|c|c|c|c|c|}
\hline $\begin{array}{l}\text { Finest } \\
\text { Taxa }\end{array}$ & Common Name & & $\begin{array}{l}\text { Upper } \\
\text { Component }\end{array}$ & $\begin{array}{l}\text { Lower } \\
\text { Component }\end{array}$ \\
\hline \multirow[t]{3}{*}{ Elasmobranchii } & Sharks and Rays & Count & 15 & 27 \\
\hline & & $\begin{array}{l}\text { Expected } \\
\text { Count }\end{array}$ & 26.7 & 15.3 \\
\hline & & Std. Residual & -2.3 & 3.0 \\
\hline \multirow{3}{*}{$\begin{array}{l}\text { Clupeiformes } \\
\text { (dominated by } C \text {. } \\
\text { pallasii) }\end{array}$} & $\begin{array}{l}\text { Herring and } \\
\text { Anchovy }\end{array}$ & Count & 119 & 52 \\
\hline & & $\begin{array}{l}\text { Expected } \\
\text { Count }\end{array}$ & 108.7 & 52.3 \\
\hline & & Std. Residual & 1.0 & -1.3 \\
\hline \multirow[t]{3}{*}{ Oncorhynchus sp. } & Pacific Salmon & Count & 44 & 44 \\
\hline & & $\begin{array}{l}\text { Expected } \\
\text { Count }\end{array}$ & 56 & 32 \\
\hline & & Std. Residual & -1.6 & 2.1 \\
\hline \multirow[t]{3}{*}{$\begin{array}{l}\text { Gadidae (dominated } \\
\text { by G. } \\
\text { macrocephalus) }\end{array}$} & Codfish & Count & 66 & 43 \\
\hline & & $\begin{array}{l}\text { Expected } \\
\text { Count }\end{array}$ & 69.3 & 39.7 \\
\hline & & Std. Residual & -.4 & .5 \\
\hline \multirow[t]{3}{*}{ Cottidae } & Sculpin & Count & 45 & 13 \\
\hline & & $\begin{array}{l}\text { Expected } \\
\text { Count }\end{array}$ & 36.9 & 21.1 \\
\hline & & Std. Residual & 1.3 & -1.8 \\
\hline \multirow[t]{3}{*}{ Small Cottid } & & Count & 61 & 27 \\
\hline & & $\begin{array}{l}\text { Expected } \\
\text { Count }\end{array}$ & 56 & 32 \\
\hline & & Std. Residual & .7 & -.9 \\
\hline \multirow[t]{3}{*}{ Large Cottid } & & Count & 31 & 18 \\
\hline & & $\begin{array}{l}\text { Expected } \\
\text { Count }\end{array}$ & 31.2 & 17.8 \\
\hline & & Std. Residual & .0 & .0 \\
\hline \multirow[t]{3}{*}{ Pleuronectiformes } & Flatfish & Count & 16 & 7 \\
\hline & & $\begin{array}{l}\text { Expected } \\
\text { Count }\end{array}$ & 14.6 & 8.4 \\
\hline & & Std. Residual & .4 & -.5 \\
\hline
\end{tabular}

Overall, the distribution of taxa across components shows some interesting patterns; all chi square tests yielded statistically significant results. In both " $C$ " bag samples, the Clupeiformes category primarily drove the statistical significance; in 
the "CX" sample, the assemblage was more evenly distributed over both assemblages. A combination of these results could indicate a greater reliance on larger bodied fish in the lower component, shifting to a greater focus on small Clupeiformes in the upper component, though all taxa are represented throughout the occupation of the site samples in the $2 \times 2 \mathrm{~m}$ unit. This suggests that, even with the occupation gap reflected in this $2 \times 2$, fish resources and fishing techniques appear continuous throughout the occupation. A shift in reliance from one resource to another represented by changing relative abundances before and after the occupation gap (like the example outlined above) could indicate a response to a coseismic event, but it is striking that all taxa are represented throughout the occupation. With this in mind, I now turn to a discussion addressing the potential for this assemblage to reflect fish and human response to a CSZ coseismic event. 


\section{Discussion}

Chapter 2 reviewed the evidence for human and animal response to coseismic events along the CSZ, especially relating to marine fish resources and effects on their habitats. Here, I discuss my expectations, based on Losey's (2002) study. I then review archaeological evidence relating to human responses to these events, specifically in terms of marine resources. Representation of fish resources through time, via their habitat types, is used to understand possible changes in fish populations at Tse-whit-zen, especially focusing on the AZs surrounding a gap of 300 years that may indicate a CSZ coseismic event. I outline possible explanations for changes, and what they may mean in terms of fish and human vulnerability at Tsewhit-zen.

\section{Expectations}

Overall, I expect to see that if resources were indeed affected by short or long-term effects of a CSZ earthquake, a change in taxonomic structure would occur around the time of one of these events. I expect that long-term environmental effects of a seismic event, as opposed to immediate population loss, would have the largest impact on relative species abundances. Fish population losses would vary in severity depending on the season, however. If a tsunami occurred during a seasonal spike in fish abundance, when salmon were beginning to run upriver, for example, there 
could have been a reduction of the population, which would have had a direct impact on the people that relied on that seasonal abundance.

Habitat loss would be the most problematic for nearshore fish. Scouring of the substrate from a tsunami would affect the nearshore bottom fish, including species of flatfish. Loss of nearshore marine plants, habitat needed for many marine species for shelter and spawning grounds, would have been problematic. Herring populations, for example, spawning inshore at the time of a tsunami would have suffered dramatic losses due to loss of eelgrass and kelp beds on which they deposit their eggs.

It is also important to consider other alternatives for changes in relative fish abundances post-earthquake, though the direct cause of the change in fish abundance over time may be impossible to separate in the archaeological record. Loss of important harvesting gear due to a tsunami could have made it much more difficult for the human population to capture some of their important resources, which could also explain changes in relative species abundance in the record. Loss of boats would have made it impossible to capture larger bottom fish, such as red Irish lord, cabezon, or sablefish. Loss of mass capture gear such as fish weirs, rakes, and nets would have made it extremely difficult to harvest smaller, schooling fish such as herring. The possible loss of technology may have been a factor in changes in relative species abundances that show up within the archaeological record that have nothing to do with effects on the fish populations themselves, but on the human ability to capture them. 
Overall, I expect that regardless of loss of fish habitat or loss of fishing gear after a coseismic event, the observable response in the archaeological record would be a shift to more nearshore fisheries. These shallow water fisheries may recover faster than other habitats; Losey (2002) states eelgrass beds would be rejuvenated quickly. Even if the sandy bottom was scoured away due to a tsunami, more silt would be deposited as part of the tsunami as well, which further suggests this particular habitat could rejuvenate faster than others. Furthermore, this shallow water, sandy bottom habitat would not require as much specialized equipment to access. If canoes, weirs, nets, and rakes were lost, these areas would still be accessible to village occupants.

\section{Habitat Assignment}

In order to test my expectations relating to changes in relative species abundance after a coseismic event at Tse-whit-zen, I grouped the fish taxa into different habitat types. These habitat types, which are distinct foraging patches, include the sandy substrate and eelgrass habitat, the rocky substrate and kelp forest habitat, the Elwha River (salmon stream), and the open water (Fig 5.1). These four habitat definitions allowed me to group fish taxa that could have been captured at the same time, with similar technology, in order to simplify the attempt to track the large number of different fish taxa through time.

The first habitat I defined as the nearshore, sandy substrate and eelgrass habitat. This is a generalized patch nearest to the shore where a variety of small taxa 
live year round. The next patch encompasses the slightly deeper water of the nearshore environment, and is defined as the rocky substrate and kelp forest habitat. Many rocky bottom fish live here year round, as well as fish that live in the kelp forest and use it for food and shelter. These two habitats have year round inhabitants, but also receive seasonal visitors that congregate during their breeding cycles (e.g. Pacific herring). As such, these habitats are defined as generalized patches, where fishers could have captured a variety of taxa at once.

The other two patches are targeted toward one species, and both have a strong seasonal aspect. One of these targeted seasonal patches is the Elwha River, which was an important salmon stream located about $10 \mathrm{~km}$ away from Tse-whitzen. Five salmonid species were historically reported to run up this stream yearly (Pess et al. 2008), and fisherman could have traveled by canoe along the shore to take advantage of these seasonal runs. The final patch is the open water, and includes only Pacific herring. These fish were gathered with herring rakes in the nearshore habitat when they congregated in the winter to spawn. Though they are captured in the eelgrass/kelp forest habitats, I consider them separately in order to understand any differences in CSZ earthquake effects on resident and highly mobile fishes. Table 5.1 shows taxa assigned to each habitat type. Spiny dogfish, though common in the assemblage, is not included in any grouping because it is behaviorally different than any of these species, and did not fit well into any habitat group. They are wanderers and can be caught near to shore. However, they do not 
remain in the inshore environment and can be found in very deep water (Hart 1973, Eschmeyer et al. 1983).

I then compared the changing reliance on each habitat type from the lower to the upper component in order to track any changes in taxonomic abundances over time. I did this with both the "C" and " $\mathrm{CX}$ " samples to see if the large bodied fish sample contributed different information than the $>1 / 8$ " "C" sample. If my expectation was met, I would see a shift in the upper component away from fisheries requiring specialized gear and away from fisheries in the deeper water habitats to more shallow water fisheries. 


\section{Table 5.1: Assignment of fish taxa to habitat}

\begin{tabular}{ll}
\hline Habitat & Taxa \\
\hline Sandy substrate, eelgrass bed & Raja sp. \\
& Hydrolagus colliei \\
& Leptocottus armatus \\
& Enophrys bison \\
& Myoxocephalus polyacanthocephalus \\
& Eopsetta jordani \\
& Platichthys stellatus \\
& Citharichthys sp. \\
& Gadus macrocephalus \\
Rocky substrate, kelp forest & Theragra chalcogramma \\
& Microgadus proximus \\
& Ophiodon elongatus \\
& Hexagrammos sp. \\
& Hemilepidotus sp. \\
Scorpaenichthys marmoratus & Sebastes sp. \\
Open water & Anoplopoma fimbria \\
& Oncorhynchus sp. \\
& Clupea pallasii \\
\hline & \\
& \\
& \\
& \\
&
\end{tabular}




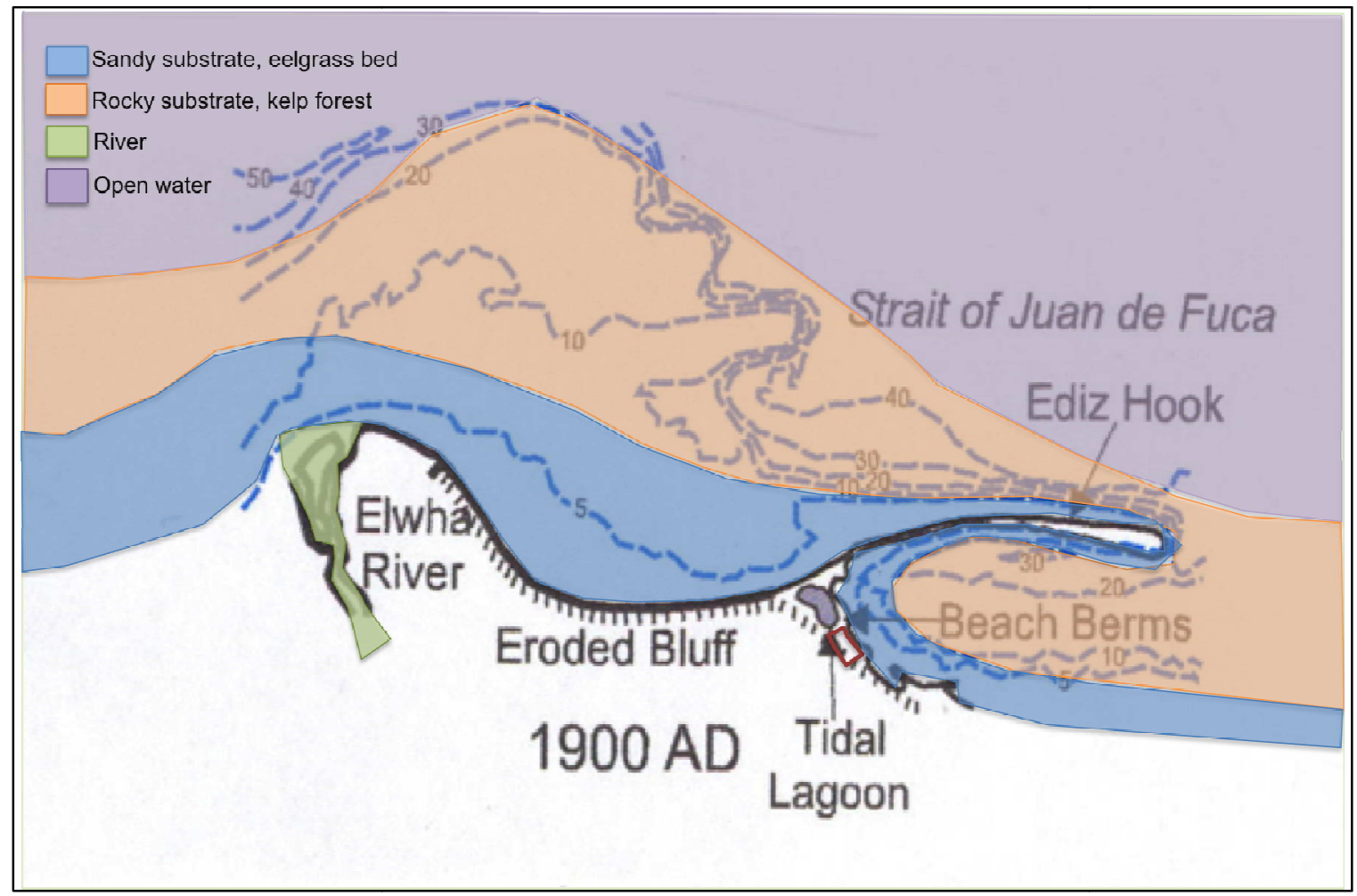

Figure 5.1: Designation of habitat types surrounding Tse-whit-zen

Change Over Time in Habitat Use

Three AZs had large enough sample sizes to be compared: A4.05, A4.03, and A4.01 (Fig 3.2). However, these three AZs encompass the time directly before the occupation break, and then both an inside and an outside portion of the upper component, after the occupation break. This is sufficient for tracking changes through time surrounding that gap. A $\chi^{2}$ analysis of the " $\mathrm{C}$ " bag data shows statistically significant difference in the distribution of these habitat types through time $\left(\chi^{2}=27.6, p<.001\right.$; Table 5.2), though not all the habitat types followed the expected shifts. 
Table 5.2: Distribution of fish in habitat types by AZ. Values in bold are significant to $\mathrm{p}=.05$

\begin{tabular}{cccccc} 
AZ & & $\begin{array}{c}\text { Shallow, } \\
\text { sandy } \\
\text { substrate }\end{array}$ & $\begin{array}{c}\text { Rocky } \\
\text { substrate }\end{array}$ & Anadromous & $\begin{array}{c}\text { Open water } \\
\text { schooling }\end{array}$ \\
\hline $\begin{array}{c}\text { A4.0 } \\
1\end{array}$ & $\begin{array}{c}\text { Count } \\
\text { Expected } \\
\text { Count } \\
\text { Std. }\end{array}$ & 95 & 43 & 26 & 51 \\
& $\begin{array}{c}\text { Residual } \\
\text { A4.0 }\end{array}$ & .9 & 48.6 & 19.3 & 60.2 \\
3 & $\begin{array}{c}\text { Count } \\
\text { Expected } \\
\text { Count } \\
\text { Std. }\end{array}$ & 251 & 115 & 1.5 & -1.2 \\
A4.0 & $\begin{array}{c}\text { Residual } \\
\text { Count }\end{array}$ & .7 & 134.3 & 36 & 192 \\
5 & $\begin{array}{c}\text { Expected } \\
\text { Count } \\
\text { Std. }\end{array}$ & 249.9 & -1.7 & 53.4 & 166.4 \\
Residual & -1.2 & 164 & -2.4 & $\mathbf{2 . 0}$ \\
\hline
\end{tabular}

The lower component shows relatively more fish from the rocky substrate habitat than expected. This had a statistically significant residual. In the upper component, the relative abundance of fishes from the rocky substrate habitat was less than expected, following my hypothesis that the upper component would show a shift away from offshore fishing grounds (Fig 5.2). This habitat, that also includes kelp forests, would require canoes to access, as well as specialized fishing gear to individually capture large bottom fish.

The sandy substrate habitat also follows this trend (Fig 5.2). In the lower component, the sandy substrate fishes comprise less of the assemblage than expected. The upper component shows a shift in focus to more of these nearshore sandy substrate fishes relative to the other habitats. Though these residuals were 
not statistically significant, the trend follows my expectation. This habitat is home to many smaller species, and does not require as elaborate fishing gear to procure as offshore patches.

This pattern is more complicated when considering the two targeted species habitats: the Elwha River (salmon) and open water (herring). Beginning with the river, I would have expected a shift away from this resource in the upper component. This is for two reasons. First, the salmon cycle itself could have suffered due to altered river conditions post-tsunami. A tsunami could add silt to the water, change the water temperature, alter the river bottom, and even create blockages in the river preventing the salmon from getting to their spawning location. All of these factors could prevent salmon from spawning, and could kill the alevins in the stream at the time of the tsunami (Losey 2002, 2005). While the shift from A4.05 to A4.03 shows a decreasing reliance on salmon that was statistically significant, the A4.01 sample, also in the upper component, showed more salmon than expected.

The possible impacts affecting this resource are variable, however. Salmon have a strong seasonal pattern, only gathering to run upstream and spawn at certain time of the year. If a tsunami struck when these fish were far out to sea, this resource would be much less affected, which could explain the relative consistency of this resource before and after the occupation gap.

The herring (open water habitat) do not follow this pattern either. Significantly more herring than expected were present in A4.03; A4.05 and A4.01 have similar proportions of herring. This resource, captured with canoes and 
herring rakes, gathers in high numbers nearshore to spawn in the winter (December to February), depositing their eggs on kelp and eelgrass (Hart 1973). Since herring rely on kelp and eelgrass for spawning habitat, and specialized equipment is necessary for the capture of these fish, I expected to see the decline of herring after the occupation gap. My results indicate that the relative abundances of herring actually increase after the gap, converse to my expectation.

Again, this could be due to the season that the coseismic event occurred. Unless the herring were inshore spawning, these large populations of schooling fish would have been away from the nearshore environment, and out of danger. As discussed above, eelgrass is expected to rebound quickly, so the habitat required for herring to spawn could have already been rehabilitated by the time these fish came inshore to spawn. For both salmon and herring, Tse-whit-zen inhabitants could have had an opportunity to rebuild their gear before the seasonal congregations of salmon and herring, again depending on the season that the event struck the village. 


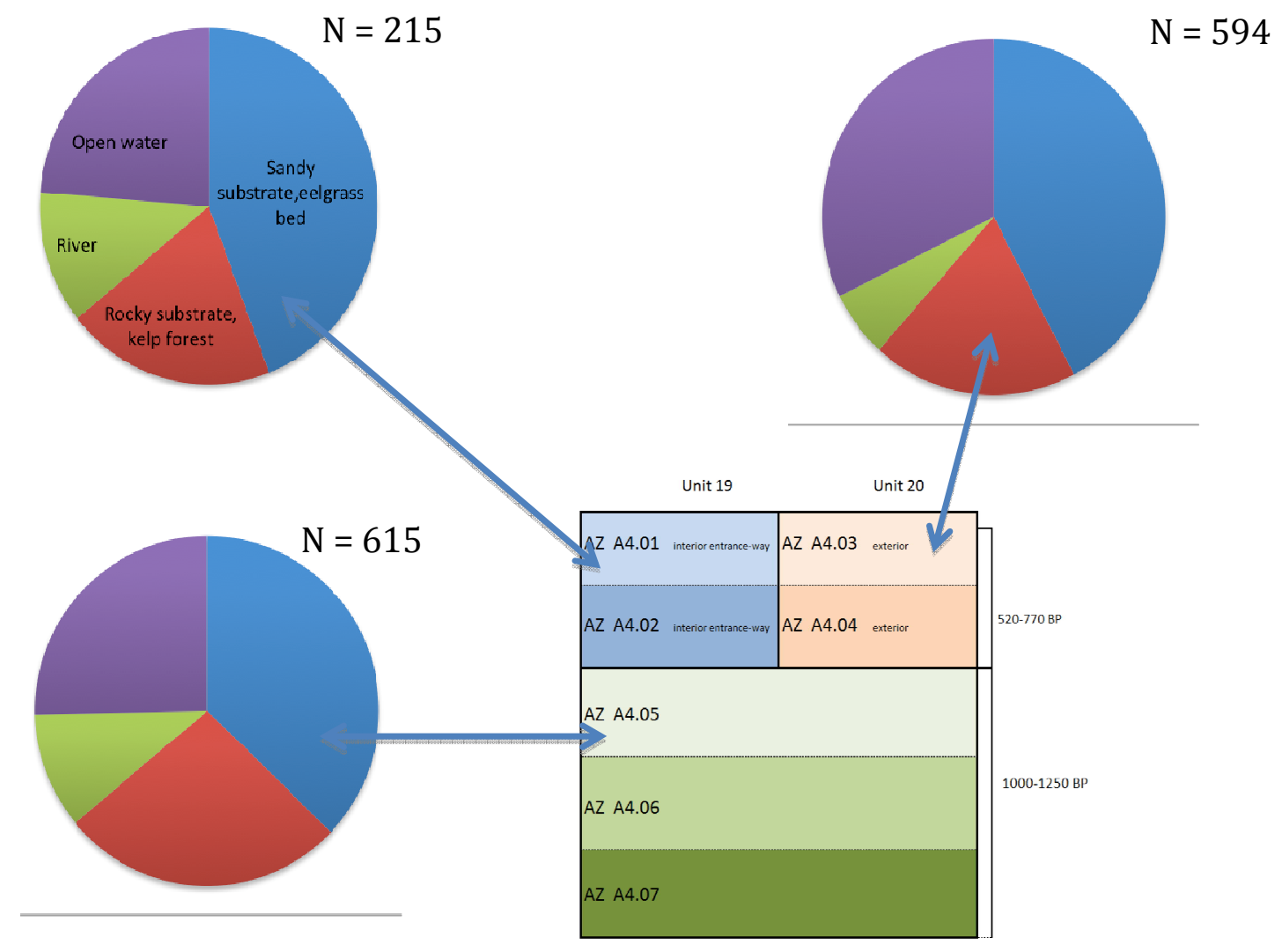

Figure 5.2: Distribution of habitat type by analytic zone before and after the occupation gap: “C” bags

The "CX" bag samples were then compared to see if this pattern was followed with just the larger bodied fish. Since the open water habitat includes only herring, which was not present at all in the "CX" sample, only three habitat types were included in this comparison. Furthermore, sample size restrictions necessitated the collapse of separate AZs into just a comparison of the lower to the upper component. The CX bag sample showed virtually no change over time from the lower to the upper component $\left(\chi^{2}=2.78, \mathrm{p}>.2\right.$; Fig 5.3), suggesting the smaller 
bodied fish are primarily driving the significant shifts in habitat use. This result further reinforces the importance of the $>1 / 8$ " screen size sample in the interpretation of fish use at this site.
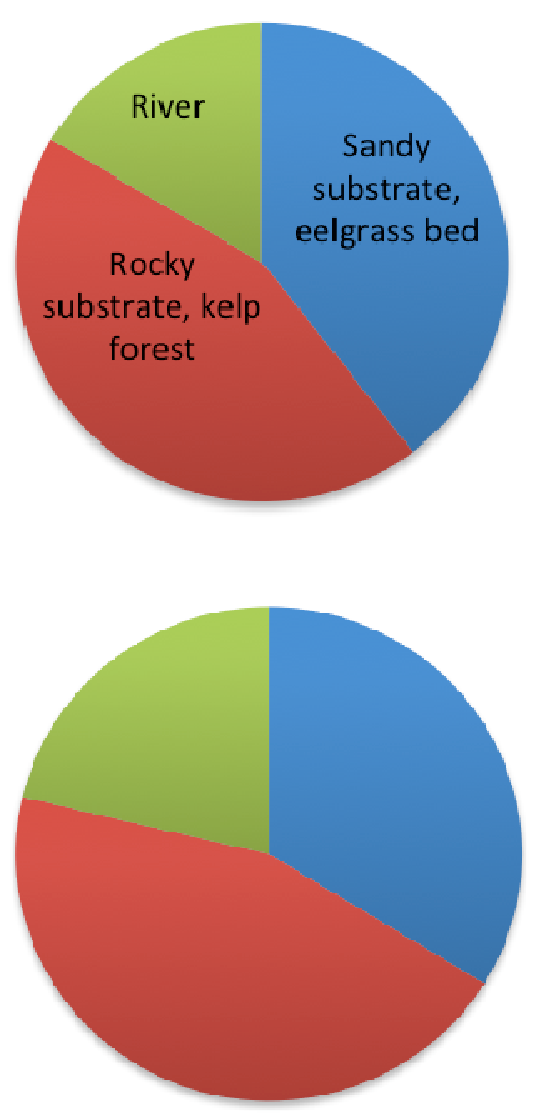

Figure 5.3: Comparison of "CX" bags from lower (bottom) to upper (top) components

The Impacts of a CSZ Coseismic Event on the Fish and Fisheries of Tse-whit-zen

Previous work regarding human responses to catastrophic events indicate that both immediate and long-term ecosystem changes would have likely affected coastal inhabitants, but it is unclear how intensely they would be affected (Hutchinson and McMillan 1997, Goff and McFadgen 2001, 2003, Losey 2002, 
papers in Reycraft and Bawden 2000, Torrence and Grattan 2007). Some villages were reoccupied after an event and abandoned after the next, some were immediately abandoned, and some were never abandoned (Hutchinson and McMillan 1997, Goff and McFadgen 2001, 2003). Some of the difficulty in interpreting the precise nature of responses comes from the extreme variability in how a coseismic event affects different parts of the coast. Coastal morphology, seafloor bathymetry, elevation of the village above sea level, and many other factors contribute to how severely an area and its resources would be affected (Saltonstall and Carver 2002).

When studying these ideas at Tse-whit-zen, it appears that no clear response to a coseismic event is visible. As shown above, the responses of the fish are more complicated to predict; many specific conditions would have to be present for Tsewhit-zen inhabitants to completely lose these resources due to a coseismic event. If these conditions did converge, the result could have been disastrous for the accumulation of winter stores and therefore survival of Tse-whit-zen inhabitants. However, based on the consistency of these resources in the record from before and after the occupation gap, it appears that the complete loss of these fisheries did not occur at Tse-whit-zen.

Overall, these results indicate that, if a tsunami did strike the village and cause the occupation gap, the fish populations may not have suffered great losses, even in the years following the event. Additionally, even if the inhabitants were not able to save any of their fishing gear, resources would have been available in the 
nearshore habitat. Depending on the season of the coseismic event, inhabitants could have even had time to rebuild their gear before the large seasonal gatherings of salmon and herring occurred. This reinforces the argument presented previously (Losey 2002, 2005, Saltonstall and Carver 2002): though these inhabitants relied on the marine environment and lived in apparently vulnerable locations, coastal people and their fish resources were ultimately resilient to the impacts of coseismic events.

The length of the occupation gap is problematic, however, in that we may be completely missing the responses of fish and humans if a coseismic event did strike Tse-whit-zen. Three hundred years could be ample time for the fish to rebound and the residents of Tse-whit-zen to resume normal fishing practices, even considering a very large earthquake. Though the patterns described above fit some of my expectations, more ${ }^{14} \mathrm{C}$ dates and further work in other areas of the site will be necessary to resolve the timing of coseismic events and the nature of human and animal responses to these events. 


\section{VI: Conclusions and Future Work}

The extended time depth, large fish assemblage, and overlap with a CSZ coseismic event in this $2 \times 2 \mathrm{~m}$ block presented an ideal starting point for attempting to assess resource and human vulnerability to a coseismic event at Tse-whit-zen. This assemblage is also comparable to other regional sites, providing a good record of the full scale of fish use in these large coastal villages. After analyzing $\sim 10,000$ fish remains from two occupation components and assigning the identified taxa into different habitat types, I assessed relative reliance on these different habitats framing a $\sim 300$ year occupation gap that may indicate the impact of a CSZ coseismic event. These results indicate that, though the generalized habitats follow my expectations of a shift from offshore to nearshore reliance, fish taxa representing all of the habitat types are present in each analytic zone, suggesting a striking amount of continuity in fishing practices at this site and resilience to the effects of a coseismic event.

Of additional value is that this work adds to the limited existing record of fish use on the Strait of Juan de Fuca. Though much of this record agrees with local sites (Hoko River and Ozette), some striking differences are present. Namely, the lack of large numbers of rockfish, surfperch, greenling and the complete lack of plainfin midshipman and lingcod in the Tse-whit-zen assemblage is striking in comparison to these other sites. Additionally, relatively little salmon is present in this assemblage. 
These discrepancies may be simply due to sampling, since this assemblage is only from one $2 \times 2 \mathrm{~m}$ unit. However, it is striking that such large discrepancies do exist; further testing will show if this reflects truly different fishing practices between these nearby sites.

In addition to these findings, this long-term record of fish use can inform on modern ecological issues on the Olympic Peninsula, especially given the recent dam removals on the Elwha River. The dams were installed in this river in the early 1900 s (Pess et al. 2008), and have prevented salmon from spawning upstream in this onceimportant salmon stream since then. Since a major focus of the dam removal is the rehabilitation of the Elwha River for salmon, the information from the excavation at Tse-whit-zen can help inform on the pre-contact abundances of salmon in the Elwha River. More work could resolve the species that were present, allowing fisheries biologists and ecologists to become more informed of the salmon species that would be using the Elwha to spawn.

In addition to the salmon focus surrounding the dam removal, the $\sim 100$ years of sediment build up behind the dams was released into the nearshore marine habitats upon the removal of these dams (Shaffer et al. 2008, Warrick et al. 2008). Recent concerns have been voiced about this excessive sediment load being deposited overtop the nearshore kelp forest at the mouth of the Elwha River. The taxonomic makeup of the fisheries at the village of Tse-whit-zen can contribute to understanding the extent of kelp forests in this area: whether or not the kelp forest is due to the dam installation or if it was native to this habitat. The relatively large 
presence of rocky bottom and kelp-dwelling fish in the assemblage from Tse-whitzen suggests kelp forests may have been widespread even before the dams were installed. Excavations closer to the river may resolve this, but clear archaeological evidence of fish that inhabit the kelp forest could indicate this excessive modern sedimentation is an issue that should be addressed to prevent their destruction.

This research is at the beginning of a multi-year project using faunal remains to assess human response to abrupt and gradual environmental change at Tse-whitzen. This thesis has served to develop the beginning framework to this larger project and also to establish the methodology for identification. I have used the fish remains to examine the relative abundances of taxa through time to assess fisheries vulnerability to coseismic events. This assemblage will then be added to the larger fish assemblage from multiple structures, which will be compared to the mammal, bird, and invertebrate record. The faunal record from different portions of the site will be used to further clarify our understanding of changes in resource use through time at Tse-whit-zen that could mirror human responses to abrupt and also gradual environmental change. 


\section{Works Cited}

Adams, John

1990 Paleoseismicity of the Cascadia Subduction Zone: Evidence from Turbidites off the Oregon-Washington Margin. Tectonics 9: 569-583.

Ames, Kenneth M.

2002 Going by Boat: The Forager-Collector Continuum at Sea. In Beyond Foraging and Collecting: Evolutionary Change in Hunter-Gatherer Settlement Systems, edited by Ben Fitzhugh and Junko Habu, pp 19-52. Kluwer Academic/Plenum Publishers. New York.

Ames, Kenneth M. and Herbert D. G. Maschner

1999 Peoples of the Northwest Coast: Their Archaeology and Prehistory. Thames and Hudson, London.

Arima, Eugene

1983 The West Coast People: The Nootka of Vancouver Island and Cape Flattery. British Columbia Provincial Museum Special Publication: 6. Victoria, British Columbia.

Atwater, Brian F.

1987 Evidence for Great Holocene Earthquakes Along the Outer Coast of Washington State. Science 236: 942-944.

Atwater, Brian F., Martitia P. Tuttle, Eugene S. Schweig, Charles M. Rubin, David K. Yamaguchi, and Eileen Hemphill-Haley

2004 Earthquake Recurrence Inferred from Paleoseismology. In The Quaternary

Period in the United States, edited by A. R. Gillespie, S. C. Porter, and B. F.

Atwater, pp. 331-350. Developments in Quaternary Science, 1 (series editor, Jim Rose). Elsevier, Amsterdam.

Atwater, Brian F., Musumi-Rokkaku Satoko, Satake Kenji, Tsuji Yoshinobu, Ueda Kazue, and David K. Yamaguchi

2005 The Orphan Tsunami of 1700: Japanese Clues to a Parent Earthquake in North America. U.S. Geological Survey, Reston, VA.

Bednarek, Angela

2001 Undamming Rivers: A Review of Ecological Impacts of Dam Removal. Environmental Management 27: 803-814.

Benson, Boyd E., Brian F. Atwater, David K. Yamaguchi, Lorin J. Amidon, Sarah L. Brown, and Roger C. Lewis. 
2001 Renewal of Tidal Forests in Washington State after a Subduction Earthquake in A.D. 1700. Quaternary Research 56: 139-147.

Butler, Virginia L.

1987 Fish Remains. In Duwamish No. 1 Site; A Lower Puget Sound Shell Midden. University of Washington Office of Public Archaeology, Research Report 1.

1990 Distinguishing Natural from Cultural Salmonid Deposits in Pacific Northwest North America. Unpublished Ph. D. Dissertation, University of Washington, Seattle, Washington.

1993 Natural vs. Cultural Salmonid Remains: Origin of the Dalles Roadcut Bones, Columbia River, Oregon. Journal of Archaeological Science 20: 1-24.

1996 Tui Chub Taphonomy and the Importance of Marsh Resources in the Western Great Basin of North America. American Antiquity 61: 699717.

Butler, Virginia L. and James C. Chatters

1994 The Role of Bone Density in Structuring Prehistoric Salmon Bone Assemblages. Journal of Archaeological Science 21: 413-424.

Byram, R. Scott

2002 Brush Fences and Basket Traps: The Archaeology and Ethnohistory of Tidewater Weir Fishing on the Oregon Coast. Unpublished Ph.D. dissertation, Department of Anthropology, University of Oregon, Eugene.

Campbell, Sarah K. and Virginia L. Butler

2011 Prehistoric Native American Use of Animals on the Northwest Coast and Plateau. In The Subsistence Economies of Indigenous North American Socities: A Handbook, edited by Bruce D. Smith, pp. 83-111. Smithsonian Institution Scholarly Press, Washington, D.C.

Cannon, Michael D.

1999 A Mathematical Model of the Effects of Screen Size on Zooarchaeological Relative Abundance Measures. Journal of Archaeological Science 26: 205214.

Casteel, R.W.

1972 Some Archaeological Uses of Fish Remains. American Antiquity 37: 404-419.

1976 Fish Remains in Archaeology and Paleo-environmental Studies. Academic Press, New York. 
Clothier, Charles R.

1950 A Key to Some Southern California Fishes Based on Vertebral Characteristics. Fish Bulletin No. 89, California Department of Natural Resources, Division of Fish and Game, Bureau of Marine Fisheries.

Croes, Dale R. and Eric Blinman (editors)

1980 Hoko River: A 2500 Year Old Fishing Camp on the Northwest Coast of North America. Washington State University Laboratory of Anthropology Reports of Investigations No. 58. Hoko River Archaeological Project Contribution No. 1. Pullman, Washington.

Drucker, Philip

1965 Cultures of the North Pacific Coast. Chandler Publishing Company, Scranton.

Eschmeyer, William N., Earl S. Herald and Howard Hammann

1983 A Field Guide to Pacific Coast Fishes. Houghton Mifflin Company, New York.

FAO

2005 Regional Workshop on Rehabilitation of Fisheries and Aquaculture in Coastal Communities of Tsunami Affected Countries in Asia, 28 February - 1 March 2005. FAO Regional Office for Asia and the Pacific, Bangkok, Thailand. RAP publication 2005/06.

Friedman, Edward and Dale R. Croes

1980 Fauna. In Hoko River: A 2500 Year Old Fishing Camp on the Northwest Coast of North America. Edited by Dale R. Croes and Eric Blinman, Washington State University Laboratory of Anthropology Reports of Investigations No. 58. Hoko River Archaeological Project Contribution No. 1. Pullman, Washington.

Goff, James R. and Bruce G. McFadgen

2001 Catastrophic Seismic-Related Events and Their Impact on Prehistoric Human Occupation, New Zealand. Antiquity 75: 155-182.

2003 Large Earthquakes and the Abandonment of Prehistoric Coastal Settlements in $15^{\text {th }}$ Century New Zealand. Geoarchaeology 18: 609-623.

Goldfinger, Chris, C. Hans Nelson, and Joel E. Johnson

2003 Holocene Earthquake Records from the Cascadia Subduction Zone and Northern San Andreas Fault Based on Precise Dating of Offshore Turbidites. Annual Review of Earth and Planetary Sciences 31:555-577.

Gordon, Elisabeth A.

1993 Screen Size and Differential Faunal Recovery: A Hawaiian Example. Journal 
of Field Archaeology 20: 453-460.

Gowan, Charles, Kurt Stephenson, and Leonard Shabman

2005 The Role of Ecosystem Valuation in Environmental Decision Making: Hydropower Relicensing and Dam Removal on the Elwha River. Ecological Economics 56: 508-523.

Grattan, John and Robin Torrence (editors) 2007 Living Under the Shadow: The Cultural Impacts of Volcanic Eruptions. Left Coast Press. Walnut Creek, CA.

Grayson, Donald K.

1981 The effects of sample size on some derived measures in vertebrate faunal analysis. Journal of Archaeological Science 8: 77.

1984 Quantitative Zooarchaeology. Academic Press, New York.

Gregory, Stan, Hiram Li, and Judy Li

2002 The Conceptual Basis for Ecological Responses to Dam Removal. Bioscience 52: 713-723.

Gunther, Erna

1927 Klallam ethnography. University of Washington Publications in Anthropology 1(5): 171-314.

Guidoboni, Emanuela and John E. Ebel

2009 Earthquakes and Tsunamis in the Past: A Guide to Techniques in Historical Seismology. Cambridge University Press, New York.

Hanna, G. Dallas

1966 Biological Effects of the Alaska Earthquake, March 17, 1964: General Report. National Academy of Sciences, Washington, D.C.

Hart, J.L.

1973 Pacific Fishes of Canada. Fisheries Research Board of Canada, Volume 180. Ottawa, Ontario.

Hemphill-Haley, Eileen

1995 Diatom Evidence for Earthquake-Induced Subsidence and Tsunami $300 \mathrm{Yr}$ Ago in Southern Coastal Washington. Geological Society of America Bulletin 107: 367-378.

Huber, Harriet R., Jeffrey C. Jorgensen, Virginia L. Butler, Greg Baker and Rebecca Stevens 
2011 Can salmonids (Oncorhynchus spp.) be identified to species using vertebral morphometrics? Journal of Archaeological Science 38: 136-146.

Huelsbeck, David R.

1994 Mammals and Fish in the Subsistence Economy of Ozette. In Ozette Archaeological Project Research Reports, Volume II: Fauna. Edited by Stephen R. Samuels. Reports of Investigations 66, Washington State University Department of Anthropology. Pullman, WA. National Park Service, Pacific Northwest Regional Office, Seattle, WA.

Huelsbeck, David and Dale R. Croes

1980 Fish Habitat Zones. In Hoko River: A 2500 Year Old Fishing Camp on the Northwest Coast of North America. Edited by Dale R. Croes and Eric Blinman, Washington State University Laboratory of Anthropology Reports of Investigations 58. Hoko River Archaeological Project Contribution No. 1. Pullman, Washington.

Hutchinson, Ian and Alan D. McMillan

1997 Archaeological Evidence for Village Abandonment Associated with Late Holocene Earthquakes at the Northern Cascadia Subduction Zone. Quaternary Research 48: 79-87.

Jacoby, Gordon C., Daniel E. Bunker, and Boyd E. Benson

1997 Tree-ring Evidence for an A.D. 1700 Cascadia Earthquake in Washington and Northern Oregon. Geology 29: 999-1002.

Kozloff, Eugene L.

1973 Seashore Life of Puget Sound, the Strait of Georgia, and the San Juan Archipelago. University of Washington Press, Seattle, Washington.

Larson, L. (editor)

2006 Data Recovery Excavation and Archaeological Monitoring at the Tse-Whit-zen Site (45CA523). Larson Anthropological Archaeological Services Limited, Gig Harbor, Washington. Final report submitted to Washington State Department of Transportation, Tumwater, Washington.

Lewarch, Dennis E. and Lynn L. Larson

2004 Final WSDOT Port Angeles Graving Dock Facility Treatment and Monitoring Plans for the Tse-whit-zen Site (45CA523) and Shotwell Recycling Property Recovery, Port Angeles, Clallam County, Washington. Larson Anthropological Archaeological Services, Limited, Gig Harbor, Washington. LAAS Technical Report \#2004-05. Submitted to the Washington State Department of Transportation, Olympic Region, Tumwater, Washington. 
Losey, Robert

2002 Communities and Catastrophe: Tillamook Response to the AD 1700 Earthquake and Tsunami, Northern Oregon Coast. Ph. D. Dissertation, University of Oregon, Eugene, OR. University Microfilms International, Ann Arbor, MI.

2005 Earthquakes and Tsunami as Elements of Environmental Disturbance on the Northwest Coast of North America. Journal of Anthropological Archaeology 24: 101-116.

Lyman, R. Lee

1995 Determining when rare (zoo-) archaeological phenomena are truly absent. Journal of Anthropological Method and Theory 2: 369-412.

2008 Quantitative Paleozoology. Cambridge University Press, Cambridge.

Lyman, R. Lee and Kenneth M. Ames

2007 On the use of species-area curves to detect the effects of sample size. Journal of Archaeological Science 34: 1985-1990.

Matson, R. G., and Gary Coupland 1994 The Prehistory of the Northwest Coast. Left Coast Press, Walnut Creek, CA.

McKechnie, Iain

2005 Five Thousand Years of Fishing at a Shell Midden in the Broken Group Islands, Barkley Sound, British Columbia. Unpublished M.A thesis, Department of Archaeology, Simon Fraser University, Burnaby.

McMillan, Alan D.

1999 Since the Time of the Transformers: The Ancient Heritage of the Nuu-chahnulth, Ditidaht, and Makah. UBC Press, Vancouver.

Miller, Bruce S., Charles A. Simenstad, Jeffrey N. Cross, Kurt L. Fresh, and S. Nancy Steinfort

1980 Nearshore Fish and Macroinvertebrate Assemblages Along the Strait of Juan de Fuca Including Food Habits of the Common Nearshore Fish. Marine Ecosystems Analysis, Puget Sound Region. Seattle, Washington.

Minor, Rick and Wendy C. Grant

1996 Earthquake-Induced Subsidence and Burial of Late Holocene Archaeological Sites, Northern Oregon Coast. American Antiquity 61: 772-781.

Moss, Madonna L.

2011 Northwest Coast: Archaeology as Deep History. SAA Press, Washington, D.C. 
National Academy of Sciences

1971 The Great Alaskan Earthquake of 1964: Biology. National Academy of Sciences, Washington D.C.

Newman, Thomas M.

1959 Tillamook Prehistory and its Relation to the Northwest Coast Culture Area. Unpublished Ph.D. dissertation, University of Oregon, Eugene.

Oregon Department of Geology and Mineral Industries

1995 Cascadia Subduction Zone boundary. Electronic document, www.ccalmr.ogi.edu/tsunami, accessed June 10, 2013.

Partlow, Megan A.

2006 Sampling Fish Bones: A Consideration of the Importance of Screen Size and Disposal Context in the North Pacific. Arctic Anthropology 43: 67-79.

Pess, George R., Michael L. McHenry, Timothy J. Beechie, and Jeremy Davies 2008 Biological Impacts of the Elwha River Dams and Potential Salmonid Responses to Dam Removal. Northwest Science 82: 72-90.

Peterson, Curt D., Kenneth M. Cruikshank, Mark E. Darien 2012 Coseismic Subsidence and Paleotsunami Run-Up Records from Latest Holocene Deposits in the Waatch Valley, Neah Bay, Northwest Washington, U.S.A.: Links to Great Earthquakes in the Northern Cascadia Margin. Journal of Coastal Research 29: 157-172.

Ramachandran, S, S. Anitha, V. Balamurugan, K. Dharanirajan, K. Ezhil Vendhan, Marie Irine Preeti Divien, A. Senthil Vel, I. Sujjahad Hussain and A. Udayaraj 2005 Ecological impact of tsunami on Nicobar Islands (Camorta, Katchal, Nancowry and Trinkat). Current Science: 89: 195-200.

Reetz, Elisabeth C. Dennis E. Lewarch, Stephanie E. Trudel, Nichole Gillis, Hayley E.

Kanipe, Sarah L. Sterling, Donald E. Tatum, and Sherry Kekkonen

2006 Field Techniques. In Data Recovery Excavation and Archaeological Monitoring at the Tse-whit-zen Site (45CA523),Clallam County, Washington, edited by L. Larson, pp. 7-1:7-109. Larson Anthropological Archaeological Services Limited, Gig Harbor, Washington. Submitted to Washington State Department of Transportation, Olympia Region.

Reitz, Eizabeth J., and Elizabeth S. Wing 2008 Zooarchaeology, 2nd edition. Cambridge Manuals in Archaeology, Cambridge University Press, Cambridge.

Reycraft, Richard M. and Garth Bawden 
2000 Introduction. In Environmental Disaster and the Archaeology of Human Response, edited by G. Bawden and R.M. Reycraft,1-10. Anthropological Papers No. 7, Maxwell Museum of Anthropology, Albuquerque.

Sakamoto, Kazuo

1984 Interrelationships of the Family Pleuronectidae (Pisces: Pleuronectiformes). Memoirs of the Faculty of Fisheries, Hokkaido University 31 (1,2): 95-215.

Saltonstall, Patrick and Gary A. Carver

2002 Earthquakes, Subsidence, Prehistoric Site Attrition and the Archaeological Record: A View From the Settlement Point Site, Kodiak Archipelago, Alaska. In Natural Disasters and Cultural Change, edited by R. Torrence and J. Grattan, pp. 172-192. One World Archaeology Series Volume 45. Routledge, New York.

Satake, Kenji, Kelin Wang, and Brian F. Atwater

2003 Fault Slip and Seismic Moment of the 1700 Cascadia Earthquake Inferred from Japanese Tsunami Descriptions. Journal of Geophysical Research 108(B11): 25-35.

Satake, Kenji and Brian F. Atwater

2007 Long-Term Perspectives on Giant Earthquakes and Tsunamis at Subduction Zones. Annual Review of Earth and Planetary Sciences 35: 349-374.

Schultz, Stewart T.

1990 The Northwest Coast: A Natural History. Timber Press, Portland, OR.

Shaffer, J. Anne, Patrick Crain, Brian Winter, Cathy Lear, and Timothy J. Randle 2008 Nearshore Restoration of the Elwha River through Removal of the Elwha and Glines Canyon Dams: An Overview. Northwest Science 82: 48-58.

Stanley, Kirk W.

1968 Effects of the Alaska Earthquake of March 27, 1964 on Shore Processes and Beach Morphology. Geological Survey Professional Paper 543-J. U.S. Government Printing Office, Washington, D.C.

Sterling, Sarah L., Adam Freeburg, and Christopher Milton

2013 Potential Uses for GIS in the Analysis of Deposits at Tse-whit-zen. Paper presented at the $66^{\text {th }}$ Annual Northwest Anthropological Conference, Portland.

Sterling, Sarah L., Kristine M. Bovy, Virginia L. Butler, Sarah K. Campbell, Michael A. Etnier

2011 Beyond the Palimpsest: Using High-Resolution Techniques to Evaluate Household Scale Economic Strategies and Earthquake Response on the 
Northwest Coast. Poster Presented at the $76^{\text {th }}$ Annual Meeting of the Society of American Archaeology, Sacramento.

Sterling, Sarah L., Dennis E. Lewarch, Donald E. Tatum, Jenny L. Dellert, Elizabeth C. Reetz, Stephanie, E. Trudel, and Nichole Gillis

2006 Stratigraphy and Geoarchaeology of the Tse-whit-zen Site (45CA523). In

Data Recovery Excavation and Archaeological Monitoring at the Tse-whit-zen

Site (45CA523),Clallam County, Washington, edited by L. Larson, pp. 7-1:7109. Larson Anthropological Archaeological Services Limited, Gig Harbor, Washington. Submitted to Washington State Department of Transportation, Olympia Region.

Stiros, Stathis C.

2001 The AD 365 Crete Earthquake and Possible Seismic Clustering During the Fourth and Sixth Centuries AD in the Eastern Mediterranean: A Review of Historical and Archaeological Data. Journal of Structural Geology 23: 545-562.

Suttles, Wayne

1974 The Economic Life of the Coast Salish of Haro and Rosario Straits. Garland Publishing, Inc, New York.

Suttles, Wayne (editor)

1990 Northwest Coast. Handbook of North American Indians Volume 7. Smithsonian Institution, Washington D.C.

Swan, J. G.

1869 The Indians of Cape Flattery at the Entrance to the Strait of Juan de Fuca, Washington Territory. Smithsonian Contributions to Knowledge, Collins, Philadelphia.

Thomson, Richard E.

1981 Oceanography of the British Columbia Coast. Canadian Special Publication of Fisheries and Aquatic Sciences 56, Ottawa, Ontario.

Torrence, Robin, and John Grattan (editors)

2002 Natural Disasters and Cultural Change. One World Archaeology Series Volume 45. Routledge, London.

Tveskov, Mark A. and Jon M. Erlandson

2003 The Haynes Inlet Wiers: Estuarine Fishing and Archaeological Site Visibility on the Southern Cascadia Coast. Journal of Archaeological Science 30: 10231035.

Warrick, Jonathan A., Guy R. Chochrane, Yael Sagy, and Guy Gelfenbaum 
2008 Nearshore Substrate and Morphology Offshore of the Elwha River, Washington. Northwest Science 82: 153-163.

Wheeler, Alwyne C. and Andrew K. Jones

1989 Fishes. Cambridge University Press, Cambridge.

Williams, Harry

1999 Foraminiferal Distributions in Tidal Marshes Bordering the Strait of Juan de Fuca: Implications for Paleoseismicity Studies. Journal of Foraminiferal Research 29: 196-208.

Woodward, John A.

1986 Prehistoric Shipwrecks on the Oregon Coast? Archaeological Evidence. In Contributions to the Archaeology of Oregon, 1983-1986, edited by Kenneth M. Ames, pp 219-264. Association of Oregon Archaeologists Occasional Papers 3.

Wunderlich, Robert C., BD Winter and JH Meyer

1994 Resotoration of the Elwha River Ecosystem. Fisheries 19(8) 11-19. 


\section{Appendices}

Appendix A: list of possible taxa for the Strait of Juan de Fuca

\begin{tabular}{|c|c|c|c|c|}
\hline Class & Order & Family & Species & Common Name \\
\hline \multirow[t]{4}{*}{ Chondrichthys } & Squaliformes & Squalidae & $\begin{array}{l}\text { Squalus } \\
\text { acanthias }\end{array}$ & Spiny dogfish \\
\hline & Rajiformes & Rajidae & Raja sp. & Skate \\
\hline & Chimaeriformes & Chimaeridae & $\begin{array}{l}\text { Hydrolagus } \\
\text { colliei }\end{array}$ & Ratfish \\
\hline & Acipenseriformes & Acipenseridae & $\begin{array}{l}\text { Acipenser } \\
\text { transmontanus }\end{array}$ & White sturgeon \\
\hline \multirow[t]{23}{*}{ Osteichthys } & Clupeiformes & $\begin{array}{l}\text { Clupeidae } \\
\text { Engrauladae }\end{array}$ & $\begin{array}{l}\text { Clupea pallasi } \\
\text { Engraulis } \\
\text { mordax }\end{array}$ & $\begin{array}{l}\text { Pacific herring } \\
\text { Anchovy }\end{array}$ \\
\hline & & & Sardinops sagax & Sardine \\
\hline & Salmoniformes & Salmonidae & $\begin{array}{l}\text { Oncorhynchus } \\
\text { sp. }\end{array}$ & Salmon \\
\hline & Osmeriformes & Osmeridae & & Smelt \\
\hline & & Batrachoididae & $\begin{array}{l}\text { Porichthys } \\
\text { notatus }\end{array}$ & $\begin{array}{l}\text { Planefin } \\
\text { midshipman }\end{array}$ \\
\hline & & Gobiesocidae & & Clingfishes \\
\hline & & Merluccidae & $\begin{array}{l}\text { Merluccius } \\
\text { productus }\end{array}$ & Hake \\
\hline & Gadiformes & Gadidae & $\begin{array}{l}\text { Microgadus } \\
\text { proximus }\end{array}$ & Pacific tomcod \\
\hline & & & $\begin{array}{l}\text { Theragra } \\
\text { chalcogramma }\end{array}$ & Walleye pollock \\
\hline & & & $\begin{array}{l}\text { Gadus } \\
\text { macrocephalus }\end{array}$ & Pacific cod \\
\hline & & Zoarchidae & & Eelpout \\
\hline & & Aulorhynchidae & $\begin{array}{l}\text { Aulorhynchus } \\
\text { flavidus }\end{array}$ & Tube-snout \\
\hline & Gasterosteiformes & Gasterosteidae & $\begin{array}{l}\text { Gasterosteus } \\
\text { aculeatus }\end{array}$ & $\begin{array}{l}\text { Three-spine } \\
\text { stickleback }\end{array}$ \\
\hline & & Sygnathidae & $\begin{array}{l}\text { Sygnathus } \\
\text { griseolineatus }\end{array}$ & Bay pipefish \\
\hline & Perciformes & Embiotocidae & $\begin{array}{l}\text { Damalichthys } \\
\text { vacca }\end{array}$ & Pile perch \\
\hline & & & $\begin{array}{l}\text { Cymatogaster } \\
\text { gracilis }\end{array}$ & Shiner perch \\
\hline & & & $\begin{array}{l}\text { Embiotoca } \\
\text { lateralis }\end{array}$ & $\begin{array}{l}\text { Striped } \\
\text { seaperch }\end{array}$ \\
\hline & & & $\begin{array}{l}\text { Amphistichus } \\
\text { rhodoterus }\end{array}$ & $\begin{array}{l}\text { Redtail } \\
\text { surfperch }\end{array}$ \\
\hline & & Sticheidae & & Prickleback \\
\hline & & Trichodontidae & $\begin{array}{l}\text { Trichodon } \\
\text { trichodon }\end{array}$ & Pacific sandfish \\
\hline & & Pholidae & & Gunnel \\
\hline & & Anarhichadidae & $\begin{array}{l}\text { Anarrhichthys } \\
\text { ocellatus }\end{array}$ & Wolf eel \\
\hline & & Ammodytidae & $\begin{array}{l}\text { Ammodytes } \\
\text { hexapterus }\end{array}$ & $\begin{array}{l}\text { Pacific } \\
\text { sandlance }\end{array}$ \\
\hline
\end{tabular}




\begin{tabular}{|c|c|c|c|}
\hline & Gobiidae & & Goby \\
\hline & Scombridae & & $\begin{array}{l}\text { Mackerel and } \\
\text { Tuna }\end{array}$ \\
\hline Scorpaeniformes & Scorpaenidae & Sebastes sp. & Rockfish \\
\hline & Anoplopomatidae & $\begin{array}{l}\text { Anoplopoma } \\
\text { fimbria }\end{array}$ & Sablefish \\
\hline & Hexagrammidae & $\begin{array}{l}\text { Hexagrammos } \\
\text { sp. }\end{array}$ & Greenling \\
\hline & & $\begin{array}{l}\text { Ophiodon } \\
\text { elongatus }\end{array}$ & Lingcod \\
\hline & Cottidae & $\begin{array}{l}\text { Leptocottus } \\
\text { armatus }\end{array}$ & $\begin{array}{l}\text { Pacific staghorn } \\
\text { sculpin }\end{array}$ \\
\hline & & Enophrys bison & Buffalo sculpin \\
\hline & & $\begin{array}{l}\text { Hemilepidotus } \\
\text { sp. }\end{array}$ & Irish lord \\
\hline & & $\begin{array}{l}\text { Myoxocephalus } \\
\text { polyacanthocep } \\
\text { halus }\end{array}$ & Great sculpin \\
\hline & & $\begin{array}{l}\text { Scorpaenichthys } \\
\text { marmoratus }\end{array}$ & Cabezon \\
\hline & Agonidae & & Poacher \\
\hline Pleuronectiformes & Pleuronectidae & $\begin{array}{l}\text { Platichthys } \\
\text { stellatus }\end{array}$ & Starry flounder \\
\hline & & Eopsetta jordani & Petrale sole \\
\hline & & $\begin{array}{l}\text { Hippoglossus } \\
\text { stenolepis }\end{array}$ & Halibut \\
\hline & & $\begin{array}{l}\text { Lepidopsetta } \\
\text { bilineata }\end{array}$ & Sand sole \\
\hline & & $\begin{array}{l}\text { Pleuronichthys } \\
\text { coenosus }\end{array}$ & C-O sole \\
\hline & Bothidae & Citharichthys $s p$. & Sanddab \\
\hline
\end{tabular}




\section{Appendix B: Comparative collection specimens for the Tse-whit-zen project}

\begin{tabular}{|c|c|c|c|c|}
\hline Class & Order & Family & Species & $\begin{array}{l}\text { Common } \\
\text { Name }\end{array}$ \\
\hline \multirow[t]{4}{*}{ Chondrichthys } & Squaliformes & Squalidae & Squalus acanthias & $\begin{array}{l}\text { Spiny } \\
\text { dogfish }\end{array}$ \\
\hline & Rajiformes & Rajidae & Raja rhina & $\begin{array}{l}\text { Longnose } \\
\text { skate }\end{array}$ \\
\hline & Chimaeriformes & Chimaeridae & Hydrolagus colliei & Ratfish \\
\hline & Acipenseriformes & Acipenseridae & $\begin{array}{l}\text { Acipenser } \\
\text { transmontanus }\end{array}$ & $\begin{array}{l}\text { White } \\
\text { sturgeon }\end{array}$ \\
\hline \multirow[t]{23}{*}{ Osteichthys } & Clupeiformes & Clupeidae & Clupea pallasi & $\begin{array}{l}\text { Pacific } \\
\text { herring }\end{array}$ \\
\hline & & & Sardinops sagax & Sardine \\
\hline & & Engrauladae & Engraulis mordax & Anchovy \\
\hline & Salmoniformes & Salmonidae & $\begin{array}{l}\text { Oncorhynchus mykiss } \\
\text { Oncorhynchus } \\
\text { tshawytscha }\end{array}$ & $\begin{array}{l}\text { Cutthroat } \\
\text { Chinook } \\
\text { Salmon }\end{array}$ \\
\hline & Osmeriformes & Osmeridae & Thaleichthys pacificus & Eulachon \\
\hline & Batrachoidiformes & Batrachoididae & Porichthys notatus & $\begin{array}{l}\text { Planefin } \\
\text { midshipman }\end{array}$ \\
\hline & Gadiformes & Merluccidae & Merluccius productus & Pacific hake \\
\hline & & Gadidae & Microgadus proximus & $\begin{array}{l}\text { Pacific } \\
\text { tomcod }\end{array}$ \\
\hline & & & $\begin{array}{l}\text { Theragra } \\
\text { chalcogramma }\end{array}$ & $\begin{array}{l}\text { Walleye } \\
\text { pollock }\end{array}$ \\
\hline & & & Gadus macrocephalus & Pacific cod \\
\hline & & Zoarchidae & Lycodopsis pacifica & $\begin{array}{l}\text { Blackbelly } \\
\text { eelpout }\end{array}$ \\
\hline & Gasterosteiformes & Aulorhynchidae & Aulorhynchus flavidus & Tube-snout \\
\hline & & Gasterosteidae & $\begin{array}{l}\text { Gasterosteus } \\
\text { aculeatus }\end{array}$ & $\begin{array}{l}\text { Three-spine } \\
\text { stickleback }\end{array}$ \\
\hline & & Sygnathidae & $\begin{array}{l}\text { Sygnathus } \\
\text { griseolineatus }\end{array}$ & Bay pipefish \\
\hline & Perciformes & Embiotocidae & $\begin{array}{l}\text { Damalichthys vacca } \\
\text { Cymatogaster } \\
\text { aggregata }\end{array}$ & $\begin{array}{l}\text { Pile perch } \\
\text { Shiner perch }\end{array}$ \\
\hline & & & Embiotoca lateralis & $\begin{array}{l}\text { Striped } \\
\text { seaperch }\end{array}$ \\
\hline & & & $\begin{array}{l}\text { Amphistichus } \\
\text { rhodoterus }\end{array}$ & $\begin{array}{l}\text { Redtail } \\
\text { surfperch }\end{array}$ \\
\hline & & Trichodontidae & Trichodon trichodon & $\begin{array}{l}\text { Pacific } \\
\text { sandfish }\end{array}$ \\
\hline & & Sticheidae & Lumpenus sagitta & $\begin{array}{l}\text { Pacific snake } \\
\text { prickleback }\end{array}$ \\
\hline & & Pholidae & Pholis ornata & $\begin{array}{l}\text { Saddleback } \\
\text { gunnel }\end{array}$ \\
\hline & & Anarhichadidae & $\begin{array}{l}\text { Anarrhichthys } \\
\text { ocellatus }\end{array}$ & Wolf eel \\
\hline & & Ammodytidae & $\begin{array}{l}\text { Ammodytes } \\
\text { hexapterus }\end{array}$ & $\begin{array}{l}\text { Pacific } \\
\text { sandlance }\end{array}$ \\
\hline & & Scombridae & Scombrer japonicas & $\begin{array}{l}\text { Pacific } \\
\text { mackerel }\end{array}$ \\
\hline
\end{tabular}




\begin{tabular}{|c|c|c|c|}
\hline \multirow[t]{15}{*}{ Scorpaeniformes } & Scorpaenidae & Sebastes caurnius & $\begin{array}{l}\text { Copper } \\
\text { rockfish }\end{array}$ \\
\hline & & Sebastes melanops & $\begin{array}{l}\text { Black } \\
\text { rockfish }\end{array}$ \\
\hline & & Sebastes ruberrimus & $\begin{array}{l}\text { Yelloweye } \\
\text { rockfish }\end{array}$ \\
\hline & Anoplopomatidae & Anoplopoma fimbria & Sablefish \\
\hline & Hexagrammidae & $\begin{array}{l}\text { Hexagrammos } \\
\text { lagocephalus }\end{array}$ & $\begin{array}{l}\text { Rock } \\
\text { greenling }\end{array}$ \\
\hline & & Hexagrammos & Kelp \\
\hline & & decagrammus & greenling \\
\hline & & Ophiodon elongatus & Lingcod \\
\hline & Cottidae & Leptocottus armatus & $\begin{array}{l}\text { Pacific } \\
\text { staghorn } \\
\text { sculpin }\end{array}$ \\
\hline & & Enophrys bison & $\begin{array}{l}\text { Buffalo } \\
\text { sculpin }\end{array}$ \\
\hline & & Hemilepidotus & Red Irish \\
\hline & & Hemilepidotus & lord \\
\hline & & $\begin{array}{l}\text { Myoxocephalus } \\
\text { polyacanthocephalus }\end{array}$ & Great sculpin \\
\hline & & $\begin{array}{l}\text { Scorpaenichthys } \\
\text { marmoratus }\end{array}$ & Cabezon \\
\hline & Agonidae & $\begin{array}{l}\text { Xeneretmus } \\
\text { triacanthrus }\end{array}$ & $\begin{array}{l}\text { Bluespotted } \\
\text { poacher }\end{array}$ \\
\hline \multirow[t]{11}{*}{ Pleuronectiformes } & Pleuronectidae & Platichthys stellatus & $\begin{array}{l}\text { Starry } \\
\text { flounder }\end{array}$ \\
\hline & & Eopsetta jordani & Petrale sole \\
\hline & & & Halibut \\
\hline & & $\begin{array}{l}\text { Lepidopsetta } \\
\text { bilineata }\end{array}$ & Sand sole \\
\hline & & $\begin{array}{l}\text { Pleuronichthys } \\
\text { coenosus }\end{array}$ & C-O sole \\
\hline & & $\begin{array}{l}\text { Glyptocephalus } \\
\text { zachirus }\end{array}$ & Rex sole \\
\hline & & Parophrys vetulus & English sole \\
\hline & & $\begin{array}{l}\text { Psettichthys } \\
\text { melanostichus }\end{array}$ & Sand sole \\
\hline & & $\begin{array}{l}\text { Microstomus } \\
\text { pacificus }\end{array}$ & Dover sole \\
\hline & & Atheristhes stomias & $\begin{array}{l}\text { Arrowtooth } \\
\text { flounder }\end{array}$ \\
\hline & Bothidae & $\begin{array}{l}\text { Citharichthys } \\
\text { sordidus }\end{array}$ & $\begin{array}{l}\text { Pacific } \\
\text { sanddab }\end{array}$ \\
\hline
\end{tabular}




\begin{tabular}{|c|c|c|c|}
\hline Taxon & MAU & Element & $\begin{array}{l}\text { Number of } \\
\text { elements in fish }\end{array}$ \\
\hline Squalus acanthias & 3 & Dorsal spine & 1 \\
\hline Hydrolagus colliei & 6 & $\begin{array}{l}\text { Upper medial } \\
\text { dental plate }\end{array}$ & 2 \\
\hline Clupea Pallasi & 112 & -Otic series & 4 \\
\hline Engraulus mordax & 1 & $\begin{array}{l}\text { Abdominal } \\
\text { vertebra }\end{array}$ & $\sim 20$ \\
\hline Onchorhynchus sp. & 3 & Vertebra Type III & 31 \\
\hline Gadidae & 3 & Caudal vertebra & $\sim 28$ \\
\hline Microgadus proximus & 4 & $\begin{array}{l}\text { Abdominal } \\
\text { vertebra }\end{array}$ & $\sim 20$ \\
\hline Gadus macrocephalus & 6 & Vomer & 1 \\
\hline Hexagrammidae & 1 & Caudal vertebra & $\sim 29$ \\
\hline Cottidae & 5 & Dentary & 2 \\
\hline Sebastes sp. & 1 & Maxilla & 2 \\
\hline Anoplopoma fimbria & 3 & Caudal vertebra & $\sim 30$ \\
\hline Hexagrammos sp. & 1 & Caudal vertebra & $\sim 29$ \\
\hline Leptocottus armatus & 10 & Quadrate & 2 \\
\hline Enophrys bison & 4 & Opercle & 2 \\
\hline Hemilepidotus sp. & 3 & Opercle & 2 \\
\hline Myoxocephalus polyacanthocephalus & 4 & Atlas & 1 \\
\hline Scorpaenichthys marmoratus & 1 & Basioccipital & 1 \\
\hline Hemilepidotus/Scorpaenichthys & 2 & Caudal vertebra & $\sim 19$ \\
\hline Embiotocidae & 1 & Lower pharyngeal & 1 \\
\hline Embiotoca/Phanerodon & 1 & Lower pharyngeal & 1 \\
\hline Damalichthys vacca & 2 & Lower pharyngeal & 1 \\
\hline Embiotoca lateralis & 1 & Lower pharyngeal & 1 \\
\hline Pleuronectidae & 2 & Maxilla & 2 \\
\hline Citharichthys sp. & 2 & Hyomandibula & 2 \\
\hline Platichthys stellatus & 1 & Dentary & 2 \\
\hline Eopsetta jordani & 1 & Maxilla & 2 \\
\hline
\end{tabular}

